\title{
Influence of Nucleobase and Anchimeric Assistance of Carboxyl Acid Groups in the Hydrolysis of Amino Acid Nucleoside Phosphoramidates
}

\author{
Munmun Maiti, ${ }^{[\mathrm{a}]}$ Servaas Michielssens, ${ }^{[\mathrm{b}]}$ Natalia Dyubankova, ${ }^{[\mathrm{a}]}$ Mohitosh Maiti, ${ }^{[\mathrm{a}]}$ Eveline \\ Lescrinier, ${ }^{[\mathrm{a}]}$ Arnout Ceulemans, ${ }^{[\mathrm{b}]}$ Piet Herdewijn $*,[\mathrm{a}]$
}

\begin{abstract}
:
Nucleoside phosphoramidates (NPs) are a class of nucleotide analogues that have been developed as potential antiviral/antitumoral prodrugs. Recently we have shown that some amino acid nucleoside phosphoramidates (aaNPs) can act as substrate for viral polymerase like HIV1 RT. Here we report the synthesis and hydrolysis study of a series of new aaNPs containing either natural or modified nucleobase in order to define the basis for their differential reactivity. Aqueous stability, kinetics and
\end{abstract}

hydrolysis pathways were studied by NMR in different solution $\mathrm{pD}$ (5-7) and temperature. It was observed that kinetics and mechanism $(\mathrm{P}-\mathrm{N}$ and/or $\mathrm{P}-\mathrm{O}$ bond cleavage) of hydrolysis largely depend on the nature of nucleobase and amino acid moiety. Aspartyl NPs were found to be more reactive than Gly or $\beta$-Ala NPs. For aspartyl NPs, the order of reactivity of nucleobase was 1-deazaadenine $>7$ deazaadenine $>$ adenine $>$ thymine $\geq 3$ deazaadenine. Notably, neutral aqueous solution of Asp-1-deaza-dAMP degraded spontaneously even at $4{ }^{\circ} \mathrm{C}$ via exclusive $\mathrm{P}-\mathrm{O}$ bond hydrolysis $(50$ fold reactivity difference of Asp-1deaza-dAMP vs. Asp-3-deaza-dAMP at pD $5,70{ }^{\circ} \mathrm{C}$ ). Conformational studies by NMR and molecular modelling suggest the involvement of protonated N3 atom of adenine and 1/7deazaadenine in the intramolecular catalysis of the hydrolysis reaction via rare syn conformation.

Keywords: synthesis $\bullet$ nucleoside
phosphoramidate $\bullet$ prodrugs
physico-chemical properties $\cdot$ NMR
spectroscopy

\section{Introduction}

Over the past decades, significant progress has been made to improve the therapeutic potency of nucleoside analogues for the treatment of viral infections, which led to the development of nucleotide prodrugs. ${ }^{[1]}$ The important feature of most nucleotide

[a] Munmun Maiti, Dr. Natalia Dyubankova, Mohitosh Maiti, Prof. Dr. Eveline Lescrinier, Prof. Dr. Piet Herdewijn Laboratory of Medicinal Chemistry Rega Institute for Medical Research, Katholieke Universiteit Leuven Minderbroedersstraat 10, 3000 Leuven, Belgium Fax: $(+) 3216337340$

E-mail: Piet.Herdewijn@rega.kuleuven.be

[b] Servaas Michielssens, Prof. Dr. Arnout Ceulemans Laboratory of Quantum Chemistry

Department of Chemistry and INPAC Institute for Nanoscale Physics and Chemistry, Katholieke Universiteit Leuven Celestijnenlaan 200F, 3001 Heverlee, Belgium prodrugs is that the negatively charged phosphate group remains masked outside the cell, allowing permeation through the lipophilic cell membrane, and the active nucleotide is processed in the cell by chemical and/or by enzymatic degradation. ${ }^{[2,3]}$ A suitable nucleotide prodrug also has to be stable in the extracellular medium so that it is not degraded outside the cell.

Nucleoside 5'-phosphoramidates (NPs) constitute one class of such prodrug candidate, pioneered by Jones et al. in the early 80's, ${ }^{[4]}$ and developed by McGuigan et al. ${ }^{[5]}$ Few years later Wagner et al. showed that also aromatic amino acid nucleoside phosphoramidates (aaNPs) with a negatively charged phosphate group could exhibit greater potency than the parent nucleoside. ${ }^{[6,7]}$ Studies on the activation pathways of aaNP triester prodrug reveal that inside the cell, esterase first catalyses hydrolysis of the carboxylic ester linkage, this results in the cleavage of the $\mathrm{P}-\mathrm{O}$-Aryl group by an intramolecular attack of the carboxylate group on the phosphorus atom giving rise to a cyclic structure which is then subsequently hydrolysed to nucleoside $5^{\prime}$-phosphoramidate. ${ }^{[8]}$ Phosphoramidase enzyme is believed to be involved in the release of the nucleoside $5^{\prime}$ monophosphate $\left(5^{\prime}-\mathrm{NMP}\right)^{[7]}$ by $\mathrm{P}-\mathrm{N}$ bond cleavage, bypassing the first crucial rate limiting $5^{\prime}$-monophosphorylation step in the kinase pathway. 5'-NMP then undergoes consecutive 5'-di- and 5'-triphosphorylation by cellular kinases which subsequently produce 


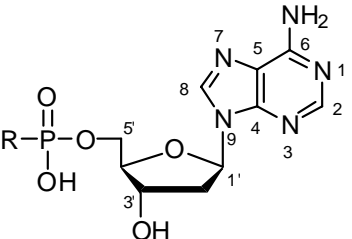

$1 \mathrm{R}=\mathrm{L}-\mathrm{Asp}$

$2 \mathrm{R}=\mathrm{Gly}$

$3 \mathrm{R}=\beta$-Ala

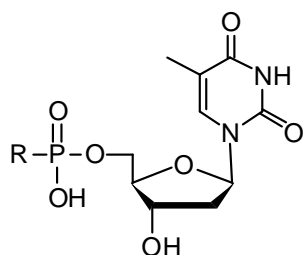

$4 \mathrm{R}=\mathrm{L}-\mathrm{Asp}$

$5 \mathrm{R}=\mathrm{Gly}$

$6 \mathrm{R}=\beta$-Ala

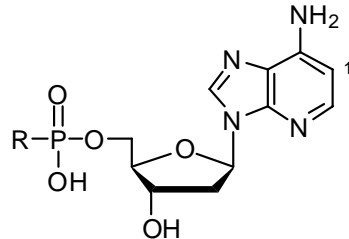

$21 \mathrm{R}=\mathrm{L}-\mathrm{Asp}$

$22 \mathrm{R}=\mathrm{Gly}$

$23 \mathrm{R}=\beta$-Ala

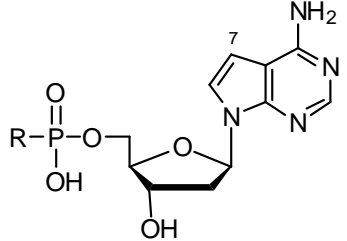

$32 \mathrm{R}=\mathrm{L}-\mathrm{Asp}$

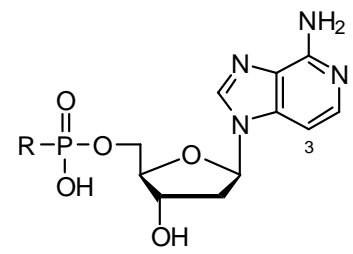

$33 \mathrm{R}=\mathrm{L}-\mathrm{Asp}$
$\mathrm{R}=$<smiles>CC(C)(C)N[C@@H](CC(=O)O)C(=O)O</smiles>

L-Asp

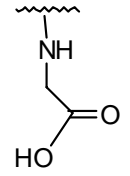

Gly

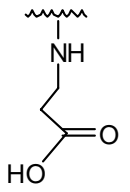

$\beta$-Ala

Figure 1: Chemical structure and atom numbering of amino acid nucleoside phosphoramidates.

their therapeutic effects as a result of DNA chain termination/polymerase inhibition. ${ }^{[3,9]}$

A considerable challenge, however, is to develop nucleotide analogues that are direct substrates/inhibitors of viral polymerases, thereby bypassing the entire cellular kinase activation cascade. Recently we have shown that some aaNPs, in particular, L-AspdAMP (1, Figure 1) and L-His-dAMP can act as direct substrate for HIV-1 reverse transcriptase (HIV-1 RT) ${ }^{[10]}$ Notably it was observed that the presence of the free carboxylic acid groups of the LAspartic acid leaving group is essential for recognition by HIV-1 RT. ${ }^{[11,12]}$ These carboxylic groups, however, are also a source of chemical instability of the NPs. Therefore it is important to study the mechanism of chemical degradation of NPs which will allow designing new modified NPs with improved properties. Recently the kinetics of hydrolysis of L-alanine methyl esters of NP prodrugs was reported and a mechanism of hydrolysis reaction in acidic and basic pH was proposed. ${ }^{[13-15]}$

However, the physico-chemical properties and the structural determinants that influence the chemical stability and hydrolysis mechanism of this class of compounds are not known in detail. We have synthesised a series of aaNPs containing either natural or modified nucleobases (Figure 1). Aqueous stability, kinetics and reaction pathways of hydrolysis have been studied in $\mathrm{pD} 5-7$ at different temperatures $\left(25,40,70{ }^{\circ} \mathrm{C}\right)$ using NMR spectroscopy. The $\mathrm{p} K_{a} \mathrm{~s}$, protonation sites and the solution conformation were investigated by NMR for compound 1, 21, 32 and 33. Experimental and theoretical studies showed that the nucleobase as well as the amino acid moiety has a large influence on the chemical stability, kinetics and hydrolysis mechanism. These data contribute to the understanding of the determinants that govern the stability and hydrolysis kinetics of aaNPs and may assist in future design of new therapeutic analogues.

\section{Results and Discussion}

Synthesis: The synthesis of methyl ester protected aaNPs (Figure 1) was performed according to the method described by Wagner et al. ${ }^{[16]}$ starting from 5'-NMP (Scheme 1A). Dimethyl L-aspartic acid is used for the synthesis of aspartyl NPs. Deprotection of methyl esters of the amino acid part was carried out with $0.4 \mathrm{M}$ sodium hydroxide in methanol/water solution at room temperature. An example of such a synthesis is shown in Scheme 1A for Asp-dAMP (1).

The synthesis of 1-deazaadenine analogues is shown in Scheme 1B. The synthesis of 2-deoxy-3,5-di- $O$ - $p$-toluoyl- $\alpha$-D-ribofuranosyl chloride (10) was carried out by a reported method ${ }^{[17]}$ in three steps starting from 2-deoxy- $\alpha / \beta$-D-ribose (Scheme 1B). Compound 15 was synthesised according to a previously described method starting from commercially available 2,3-diaminopyridine (11) with optimizations of some reaction steps for better yield. ${ }^{[18]}$ Sodium salt glycosylation of $\mathbf{1 5}$ with $\mathbf{1 0}$ is a stereospecific reaction yielding only N9 $\beta$-isomer which is then subsequently converted to $2^{\prime}$-deoxy-1deazaadenosine (18, purine numbering is followed, shown in Figure S1) by deprotection and reduction of nitro group. Compound $\mathbf{1 8}$ was phosphorylated ${ }^{[19]}$ at the $5^{\prime}$-hydroxyl group with $\mathrm{POCl}_{3}$ to obtain 19. Compound 19 was then converted into phosphoramidates 21-23 in two steps as shown in Scheme 1A.

The 7-deazaadenine (27) was synthesised according to the method described by Minakawa et al. ${ }^{[20]}$ Scheme 1C depicts the synthetic strategy followed to obtain L-Asp-7-deaza-dAMP (32). Solid-liquid phase-transfer glycosylation ${ }^{[21]}$ of 27 with 10 was performed without amino group protection using TDA-1/KOH which afforded 28 with preferred $\beta$-selectivity (57\%). Compound 28 was separated from its isomeric mixtures 28a and 28b by flash column chromatography. Compound $\mathbf{3 0}$ was converted to phosphoramidate 32 as described in Scheme 1A.

Synthesis of 2'-deoxy-3-deazaadenosine was followed according to the protocol described by Seela et $a l^{[22]} 5^{\prime}$-phosphorylation, DCC assisted coupling and methyl ester deprotection were followed analogously to obtain Asp-3-deaza-dAMP (33) as described for 
Asp-1/7-deaza analogues. Synthetic strategy is briefly shown in

Scheme 1D.

(A)

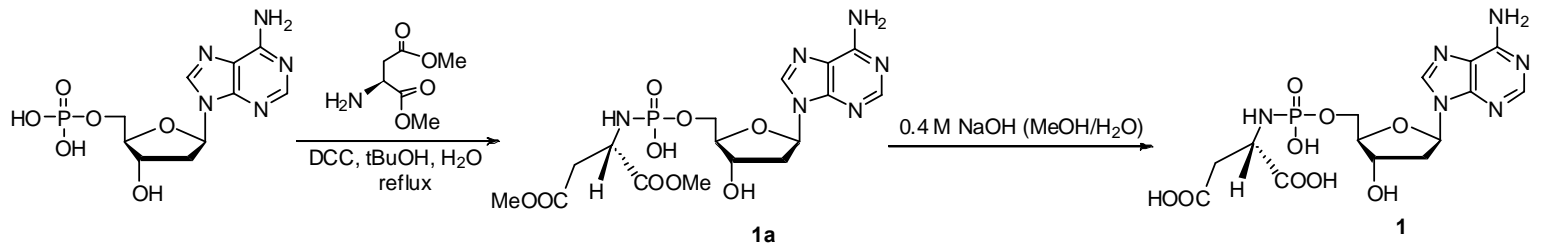

(B)
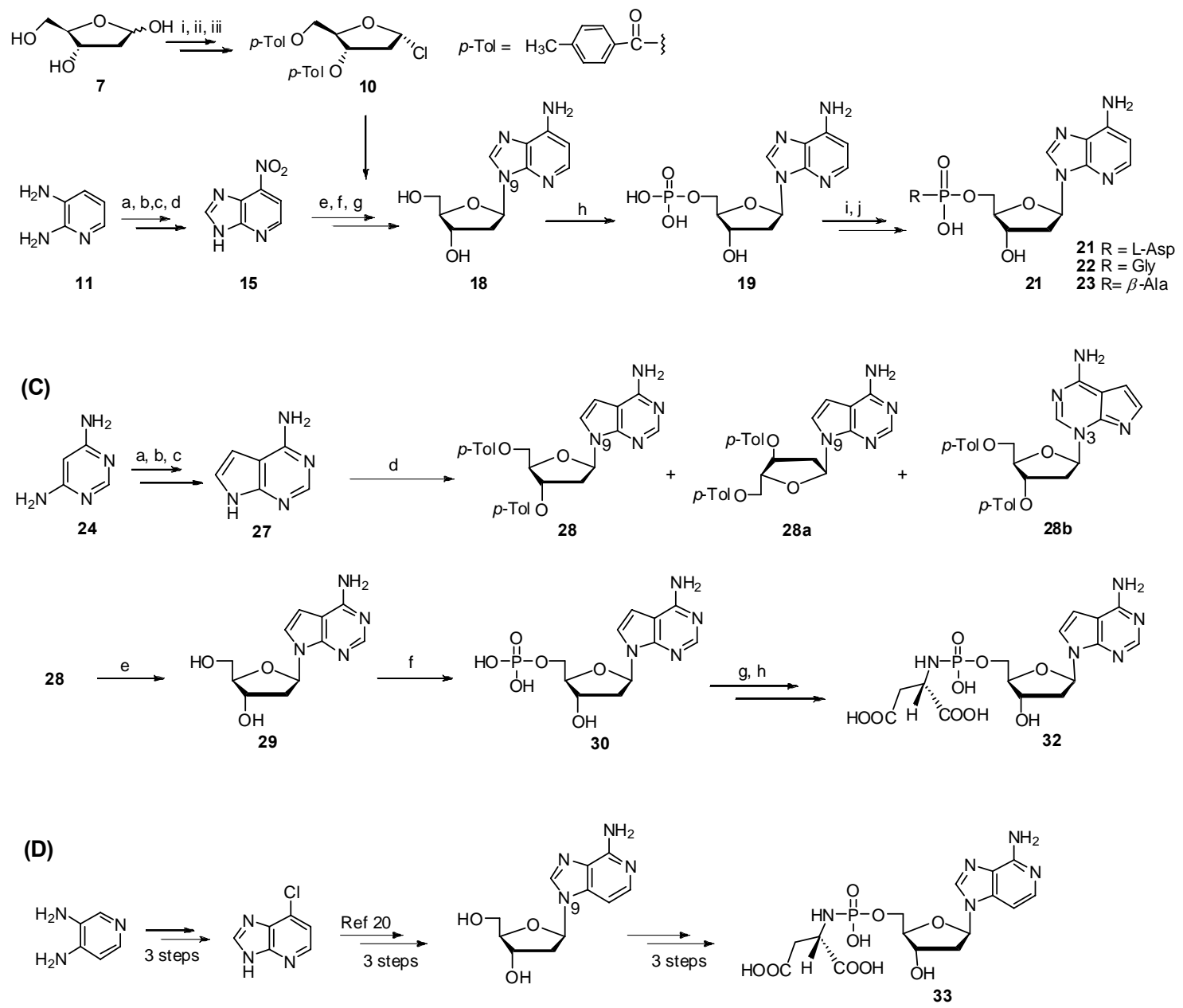

Scheme 1: (A) Dicyclohexylcarbodiimide (DCC) assisted coupling and methyl ester deprotection; (B) Synthesis of 1-deazaadenine containing phosphoramidate analogues (21-23) For detailed scheme, reagents and conditions see Scheme S1 and S2 in supporting information; (C) Synthesis of Asp-7-deaza-dAMP (32). For detailed scheme, reagents and conditions see Scheme S3 in supporting information. (D) Synthesis of Asp-3-deaza-dAMP (33).

Hydrolysis kinetics: Generally all aaNPs were found to be stable from neutral to basic solution (pD 7-10, for $21 \mathrm{pD} 8-10$ ) in $\mathrm{D}_{2} \mathrm{O}$ at room temperature for more than 24 hours, due to the existence of mono anionic phosphoramidate group. Since hydrolysis kinetics of aaNPs $(1,21$ and 32) were slow at room temperature in acidic solution (pD 5), the reaction was studied at $70{ }^{\circ} \mathrm{C}$. Knowledge of chemical stability at high temperature is important in view of the potential use of aaNPs as substrate for thermostable polymerases and/or application in PCR.
Hydrolysis was followed by ${ }^{31} \mathrm{P}$ and ${ }^{1} \mathrm{H}$ 1D NMR over $\mathrm{pD}$ 5-7 (Figure 2A). The reactions are expected to follow pseudo first-order kinetics with respect to phosphoramidate concentration, since $\mathrm{D}_{2} \mathrm{O}$ was present in large excess and there was no significant change in solution $\mathrm{pD}$ after hydrolysis. The first-order kinetics (as reported earlier for other phosphoramidates $)^{[13,23,24]}$ is also apparent from the exponential decay (Figure 3: Top left) and from the corresponding linear transformed data (Figure 3: Top right). Temperature and $\mathrm{pH}$ dependent kinetics were observed for all aaNPs i.e. faster kinetics at acidic condition (Figure S2) and at higher temperature (Figure S3). 
The acid catalysed hydrolysis demonstrates first-order dependency in hydronium ion concentration ${ }^{[13,23,25]}$ as observed by exponential pD-rate profile (Figure 3: Bottom left) and from the corresponding linear relationship (Figure 3: Bottom right). The overall first-order rate constants for the hydrolysis of aaNPs are presented in Table 1. Hydrolysis of 21 was also performed at $40{ }^{\circ} \mathrm{C}$ and the rate constants are provided in Table $\mathbf{S 1}$.
(A)

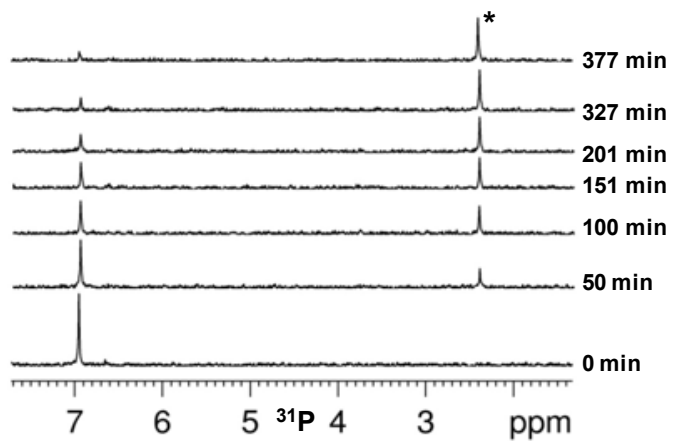

(B)

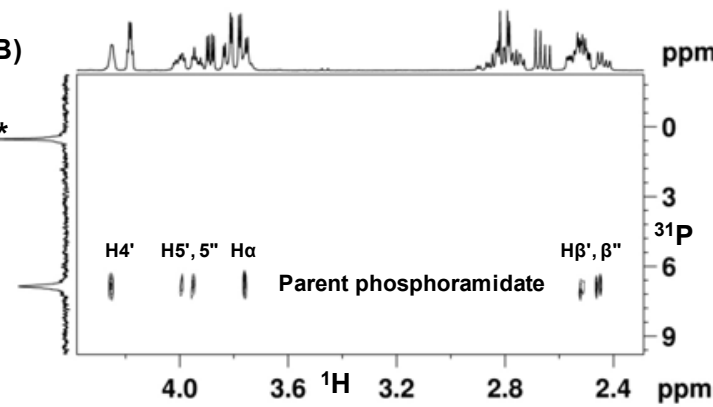

Figure 2: (A) Kinetic profile of the hydrolysis reaction of Asp-1-deaza-dAMP (21) at pD $7.0\left(T=70{ }^{\circ} \mathrm{C}\right)$, depicted by the stack plot of ${ }^{31} \mathrm{P}$ spectra at different time intervals, showing the disappearance of the parent ${ }^{31} \mathrm{P}$ peak $(\sim 7 \mathrm{ppm})$ and gradual increase of one ${ }^{31} \mathrm{P}$ peak $(\sim 2 \mathrm{ppm})$. Asterisk $\left({ }^{*}\right)$ indicates the free phosphate peak; $(\mathbf{B}){ }^{1} \mathrm{H}-{ }^{31} \mathrm{P}$ TOCSY spectrum during hydrolysis of 21 at pD $6.0\left(T=70{ }^{\circ} \mathrm{C}\right)$, depicting the formation of inorganic phosphate by $\mathrm{P}-\mathrm{O}$ bond cleavage. Inorganic phosphate $(*)$ shows no correlation with any protons, whereas, phosphoramidate ${ }^{31} \mathrm{P}$ showing correlation with $\mathrm{H} \alpha$ and $\mathrm{H} \beta$ of aspartyl group along with $\mathrm{H}^{\prime}, \mathrm{H} 5^{\prime}$ and $\mathrm{H} 5^{\prime \prime}$ of sugar moiety.

Influence of amino acid and nucleobase on reactivity: Generally rate constants from Table 1 indicate that aspartyl NPs containing both $\alpha$ and $\beta$ - $\mathrm{COOH}(1,21$ and 4) hydrolysed faster than Gly (with $\alpha$ - $\mathrm{COOH}$ ) and $\beta$-Ala (with $\beta$-COOH) NPs (Figure S4). For example, hydrolysis of Asp-1-deaza-dAMP (21) was 28 and 47-fold faster than Gly-1-deaza-dAMP (22) and $\beta$-Ala-1-deaza-dAMP (23) respectively at $\mathrm{pD}$ 6. Glycinyl NPs showed moderate reactivity whereas $\beta$-Ala NPs were less reactive in the series. The order of reactivity of the amino acids is Asp $>$ Gly $>\beta$-Ala.

The aaNPs hydrolysed either by $\mathrm{P}-\mathrm{N}$ or by $\mathrm{P}-\mathrm{O}$ bond cleavage or both pathways simultaneously (Figure S5). The hydrolysis products as well as reaction pathway were identified by ${ }^{1} \mathrm{H}^{31} \mathrm{P}$ TOCSY (Figure 2B). The $\beta$-Ala phosphoramidates (3, 6 and 23) hydrolysed solely by $\mathrm{P}-\mathrm{N}$ bond cleavage, which was independent of the nature of nucleobase (Figure S6). Hydrolysis of Gly NPs, however, underwent $\mathrm{P}-\mathrm{N}$ and/or $\mathrm{P}-\mathrm{O}$ pathways, depending on nucleobase present. In Gly-1-deaza-dAMP (22), $\mathrm{P}-\mathrm{O}$ bond hydrolysis was dominant over $\mathrm{P}-\mathrm{N}$ bond, while an opposite trend was observed in Gly-dAMP (2). However in the presence of thymine, Gly-TMP (5) hydrolysed only by $\mathrm{P}-\mathrm{N}$ bond cleavage despite the presence of $\alpha-\mathrm{COOH}$ group. In aspartyl NPs, for Asp-
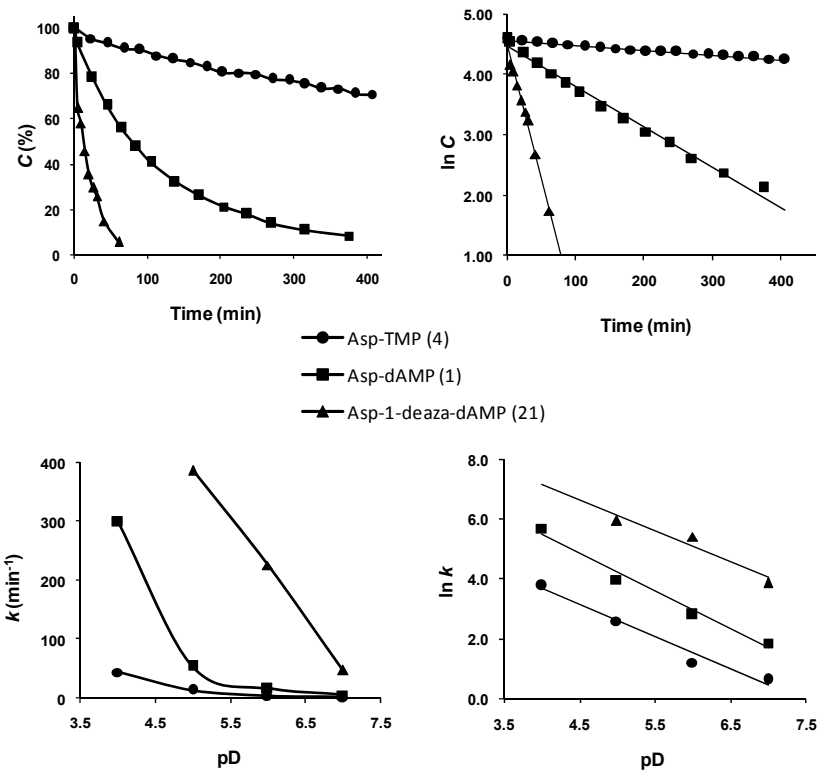

Figure 3: Kinetic plots for the acid catalysed hydrolysis of amino acid nucleoside phosphoramidates at $\mathrm{pD} 5,70{ }^{\circ} \mathrm{C}$. Exponential decay of phosphoramidates with time (Top left) and the corresponding linear relationship (Top right, $\ln C v s$. Time plot) in the hydrolysis reaction, indicating first-order kinetics with respect to phosphoramidate concentration. The exponential (Bottom left, first-order rate constant $v s . \mathrm{pD}$ ) and linear (Bottom right, ln $k$ vs. $\mathrm{pD}$ ) pD-rate profiles for the hydrolysis of nucleoside phosphosphoramidates at $70^{\circ} \mathrm{C}$, showing first-order dependency on the hydronium ion.

TMP (4) and Asp-3-deaza-dAMP (33) cleavage of the P-N bond was dominant over P-O bond, however, for Asp-dAMP (1) and Asp-7-deaza-dAMP (32) predominant cleavage of $\mathrm{P}-\mathrm{O}$ bond was detected over $\mathrm{P}-\mathrm{N}$. The most important characteristic observed for Asp-1-deaza-dAMP (21) was exclusive P-O bond hydrolysis (Figure 2).

During hydrolysis of aspartyl and glycinyl NPs (except 5), corresponding nucleoside was obtained as one of the product and its formation is not due to the hydrolysis of the nucleotide intermediate. The nucleoside was formed directly by the $\mathrm{P}-\mathrm{O}$ bond cleavage from the parent phosphoramidate. This was verified by studying the stability of the respective nucleotide at the same hydrolytic condition, where no nucleoside product was formed.

A pronounced effect of the nucleobase was observed on (stability) kinetics (Figure 3, S4) and mechanism of hydrolysis. For aspartyl NPs, the reactivity of adenine or 1/7-deazaadenine analogues were higher than thymine or 3-deazaadenine analogues. Asp-1-deaza-dAMP (21: $\left.t_{1 / 2}=18 \mathrm{~min}\right)$ hydrolysed 50 -fold faster

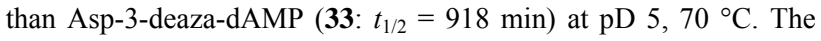
effect of 1-deazaadenine on reactivity was the highest, kinetic acceleration was observed even with Gly and $\beta$-Ala analogues. The general order of reactivity of nucleobases is 1-deazaadenine $>7$ deazaadenine $>$ adenine $>$ thymine $\geq 3$-deazaadenine. From rate constants of Asp adenine and deazaadenine conjugates, it is evident that the N3 atom of adenine base has some catalytic role since 1deaza analogue being the most reactive while 3-deaza being the least.

Accelerated kinetics with preferential $\mathrm{P}-\mathrm{O}$ bond cleavage in some of the aaNPs containing aspartyl group and adenine/deazaadenine seem to have a dual role in the intramolecular catalysis. Previously the higher reactivity of $\mathrm{N}$ diisopropylphosphoryl aspartic acid in comparison with other 
Table 1: First-order rate constants $\left(k \times 10^{-4} \mathrm{~min}^{-1}\right)$ for the hydrolysis of the amino acid nucleoside phosphoramidates at $70{ }^{\circ} \mathrm{C}(\mathrm{pD} 5.0-7.0)$. "slow" indicates the kinetics of hydrolysis are very slow at $70^{\circ} \mathrm{C}$. $\mathrm{P}-\mathrm{O}>\mathrm{P}-\mathrm{N}$ means $\mathrm{P}-\mathrm{O}$ bond cleavage is observed more than $\mathrm{P}-\mathrm{N}$ bond cleavage. Half life $\left(t_{1 / 2}\right)$ and standard error of the mean (SEM) are provided within parentheses and as \pm SEM respectively

\begin{tabular}{|c|c|c|c|c|}
\hline \multirow[b]{2}{*}{ Compound entry } & \multirow[b]{2}{*}{ Mechanism } & \multicolumn{3}{|c|}{$k \times 10^{-4}$} \\
\hline & & pD 5.0 & $\mathrm{pD} 6.0$ & $\mathrm{pD} 7.0$ \\
\hline Asp-dAMP (1) & $\mathrm{P}-\mathrm{O}>\mathrm{P}-\mathrm{N}$ & $\begin{array}{c}\mathbf{5 4 . 1 9} \pm 6.65 \\
\left(t_{1 / 2}=128 \mathrm{~min}\right)\end{array}$ & 16.65 & 6.42 \\
\hline Asp-1-deaza-dAMP (21) & $\mathrm{P}-\mathrm{O}$ & $\begin{array}{c}387.76 \pm 56.39 \\
\left(t_{1 / 2}=18 \mathrm{~min}\right)\end{array}$ & $226.46 \pm 5.50$ & $\mathbf{4 8 . 4 0} \pm 0.45$ \\
\hline Asp-7-deaza-dAMP (32) & $\mathrm{P}-\mathrm{O}>\mathrm{P}-\mathrm{N}$ & $\begin{array}{c}79.59 \pm 3.79 \\
\left(t_{1 / 2}=87 \mathrm{~min}\right)\end{array}$ & $35.80 \pm 2.09$ & 7.58 \\
\hline Asp-3-deaza-dAMP (33) & $\mathrm{P}-\mathrm{O}<\mathrm{P}-\mathrm{N}$ & $\begin{array}{c}7.55 \pm 1.47 \\
\left(t_{1 / 2}=918 \mathrm{~min}\right)\end{array}$ & slow & slow \\
\hline Asp-TMP (4) & $\mathrm{P}-\mathrm{O}<\mathrm{P}-\mathrm{N}$ & $\begin{array}{c}\mathbf{1 3 . 4 3} \pm 0.2 \\
\left(t_{1 / 2}=516 \mathrm{~min}\right)\end{array}$ & 3.33 & 1.89 \\
\hline Gly-dAMP (2) & $\mathrm{P}-\mathrm{O}<\mathrm{P}-\mathrm{N}$ & 13.8 & slow & slow \\
\hline Gly-1-deaza-dAMP (22) & $\mathrm{P}-\mathrm{O}>\mathrm{P}-\mathrm{N}$ & 62.41 & 8.24 & slow \\
\hline Gly-TMP (5) & $\mathrm{P}-\mathrm{N}$ & 4.93 & 1.23 & slow \\
\hline$\beta$-Ala-dAMP (3) & $\mathrm{P}-\mathrm{N}$ & 13.47 & 4.85 & slow \\
\hline$\beta$-Ala-1-deaza-dAMP (23) & $\mathrm{P}-\mathrm{N}$ & 46.00 & 4.85 & slow \\
\hline$\beta$-Ala-TMP (6) & $\mathrm{P}-\mathrm{N}$ & 7.96 & slow & slow \\
\hline
\end{tabular}

(A)

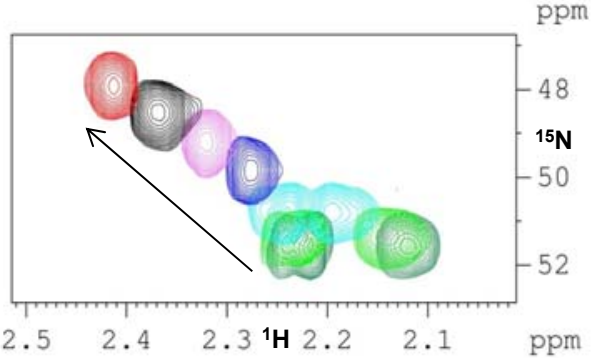

(B)

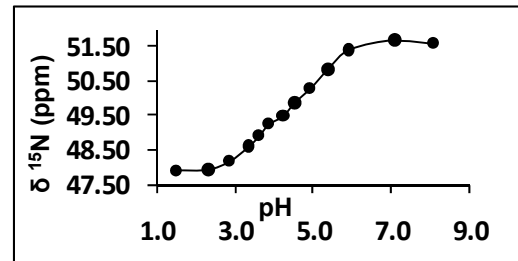

(C)

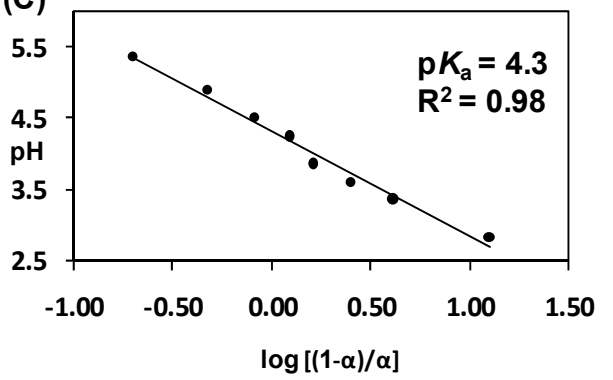

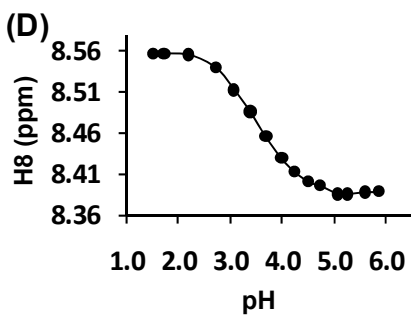

(E)

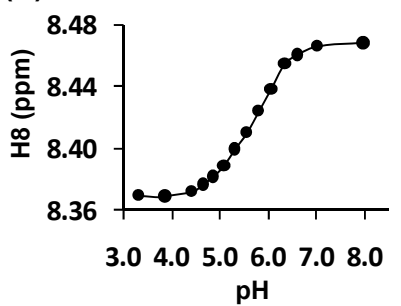
metric titration from pD 9.0 to 2.7 at $25^{\circ} \mathrm{C}$; (B) corresponding sigmoidal response of CSP; (C) Hill plot analysis of the above sigmoidal data is shown as an example; similar analysis was performed for all $\mathrm{p} K_{\mathrm{a}}$ determination; (D) Observed deshielding of the $\mathrm{H} 8$ proton of $\mathbf{1}$ during $\mathrm{pH}$-metric titration, shown by sigmoidal plot; (E) Unusual shielding (wrong way chemical shift) of the H8 proton of Asp-1-deaza-dAMP (21) in the pH-metric titration.

$N$-phosphoryl amino acids containing only $\alpha-\mathrm{COOH}$ or $\beta-\mathrm{COOH}$ group was reported. It was shown that the $\alpha-\mathrm{COOH}$ group is involved in the nucleophilic attack on phosphorus [26, 27] as neighbouring group participation reaction (NGP) during the hydrolysis resulting in the $\mathrm{P}-\mathrm{O}$ bond cleavage. ${ }^{[13]}$ The presence of an additional $\beta$ - $\mathrm{COOH}$ group was suggested to have an extra catalytic role via intramolecular hydrogen bonding. ${ }^{[26,28]}$ These suggest that in aspartyl and glycinyl NPs the $\alpha-\mathrm{COOH}$ group is involved in the $\mathrm{P}-\mathrm{O}$ bond hydrolysis. All aaNPs containing only $\beta$ - 
$\mathrm{COOH}$ group ( $\beta$-Ala) undergo acid-catalysed $\mathrm{P}-\mathrm{N}$ bond hydrolysis without involvement of any intramolecular catalysis due to the absence of $\alpha$-carboxyl group. All these observations are consistent with our kinetic data.

$\mathbf{p} K_{\mathrm{a}}$ and protonation sites: Determination of $\mathrm{p} K_{\mathrm{a}} \mathrm{s}$ and protonation sites of aspartyl adenine and 1/3/7-deazaadenine NPs $(\mathbf{1}, \mathbf{2 1}, \mathbf{3 2}, \mathbf{3 3})$ has the aim to characterise the reactive protonated tautomeric form(s) under study condition, to explain any conformational preference based on electrostatic interaction and for accurate molecular modelling which may find a rationale for the observed reactivity difference.

Nucleobase $\mathrm{p} K_{\mathrm{a}} \mathrm{s}$ were determined from the $\mathrm{pH}$ dependent chemical shift perturbation (CSP) of nucleobase protons. To obtain the $\mathrm{p} K_{\mathrm{a}}$ values of phosphoramidate nitrogen for compounds $\mathbf{1}$ and $\mathbf{2 1}$, corresponding ${ }^{15} \mathrm{~N}$ labelled aspartyl NPs were synthesised. CSP of the ${ }^{15} \mathrm{~N}$ atom (Figure 4A) showed a typical sigmoidal response (Figure 4B). The $\mathrm{p} K_{\mathrm{a}}$ value was determined from the Hill plot analysis (Figure 4C). Table 2 represents the $\mathrm{p} K_{\mathrm{a}} \mathrm{s}$ and protonation sites of aspartyl NPs.

Table 2: Protonation sites and $\mathrm{p} K_{\mathrm{a}} \mathrm{s}$ of aspartyl nucleoside phosphoramidates $(\mathbf{1}, \mathbf{2 1}, 32$ and 33) obtained by NMR pH-metric titration. Protonation site in nucleobase of 21, 32 and 33 was determined using their corresponding nucleoside (18, 29 and 2'-deoxy-3deazaadenosine respectively). $\mathrm{p} K_{\mathrm{a}}$ of the phosphoramidate nitrogen of $\mathbf{1}$ and $\mathbf{2 1}$ was determined using ${ }^{15} \mathrm{~N}$ labelled aspartyl nucleoside phosphoramidates. Marker atoms used for $\mathrm{p} K_{\mathrm{a}}$ determination are indicated within parentheses. $\mathrm{ND}=$ not determined.

\begin{tabular}{lllc}
\hline \multirow{2}{*}{ Compound entry } & Protonation & \multicolumn{2}{c}{$\mathrm{p} K_{\mathrm{a}}$} \\
\cline { 3 - 4 } & site & Nucleobase & $\begin{array}{c}\mathrm{P}-\mathrm{N} \\
\text { nitrogen }\end{array}$ \\
\hline 2'-deoxy-1-deazaadenosine (18) & $\mathrm{N} 3$ & $4.6(\mathrm{C} 2)$ & \\
2'-deoxy-7-deazaadenosine (29) & $\mathrm{N} 1$ & $4.7 \pm 0.1(\mathrm{H} 2 / \mathrm{C} 2)$ & \\
2'-deoxy-3-deazaadenosine & $\mathrm{N} 1$ & $7.5(\mathrm{H} 2)$ & \\
Asp-dAMP (1) & $\mathrm{N} 1$ & $3.6(\mathrm{H} 2)$ & $4.3\left({ }^{15} \mathrm{~N}\right)$ \\
Asp-1-deaza-dAMP (21) & $\mathrm{N} 3$ & $5.5 \pm 0.3(\mathrm{H} 1 / \mathrm{H} 2)$ & $4.1\left({ }^{15} \mathrm{~N}\right)$ \\
Asp-7-deaza-dAMP (32) & $\mathrm{N} 1$ & $4.2(\mathrm{H} 2)$ & $\mathrm{ND}$ \\
Asp-3-deaza-dAMP (33) & $\mathrm{N} 1$ & $7.4 \pm 0.1(\mathrm{H} 2)$ & $\mathrm{ND}$ \\
\hline
\end{tabular}

Determination of the protonation site of nucleobase in deazaadenine analogues $(\mathbf{2 1}, \mathbf{3 2}, \mathbf{3 3})$, was carried out using the corresponding nucleosides $(\mathbf{1 8}, \mathbf{2 9})$. In the titration of $\mathbf{1 8}, \mathrm{C} 2$ carbon in ${ }^{1} \mathrm{H}-{ }^{13} \mathrm{C}$ HSQC spectra showed up-field CSP while $\mathrm{C} 8$ carbon remains unchanged (Figure S7), clearly indicating the protonation site as N3 with $\mathrm{p} K_{\mathrm{a}}$ of 4.6 . Similarly protonation site for 2'-deoxy-3deazaadenosine was found to be $\mathrm{N} 1$ with $\mathrm{p} K_{\mathrm{a}}$ of 7.5. However, in case of $29,{ }^{1} \mathrm{H}-{ }^{13} \mathrm{C}$ HSQC spectra alone cannot provide conclusively the protonation site in the pyrimidine ring, because protonation either at N1 or N3 leads to shielding of $\mathrm{C} 2$ carbon (Figure S8). For this reason, ${ }^{1} \mathrm{H}_{-}{ }^{13} \mathrm{C}$ HMBC spectra were recorded to monitor the CSP of C4 and C6 carbon. Although up-field shifts of both $\mathrm{C} 4$ and C6 carbon were observed (Figure S9), the total change in CSP was $5.6 \mathrm{ppm}$ for $\mathrm{C} 6$, while being much smaller $(\Delta \delta=1.8 \mathrm{ppm})$ for $\mathrm{C} 4$. This suggests that the protonation likely occurs at N1 with $\mathrm{p} K_{\mathrm{a}}$ of 4.7. $\mathrm{N} 1$ atom is the protonation site for $2^{\prime}$-deoxyadenosine $\left(\mathrm{p} K_{\mathrm{a}}=\right.$ 3.8 ) as reported previously. ${ }^{[29]}$

The $\mathrm{p} K_{a}$ of 3-deazaadenine moiety in $33\left(\mathrm{ca} . \mathrm{p} K_{\mathrm{a}}=7.4\right)$ and 1deazaadenine in $21\left(c a . \mathrm{p} K_{\mathrm{a}}=5.5\right)$ is much higher than the $\mathrm{p} K_{\mathrm{a}}$ of 7deazaadenine in $32\left(\mathrm{p} K_{\mathrm{a}}=4.2\right)$ and even higher than the adenine in $1\left(\mathrm{p} K_{\mathrm{a}}=3.6\right)$. Therefore, it is clear that the population of the protonated species of $\mathbf{3 3}$ and $\mathbf{2 1}$ is higher than $\mathbf{3 2}$ and $\mathbf{1}$ in acidic solution (pD 5-7). Although the protonated forms of 33 are higher than 21 based on their $\mathrm{p} K_{\mathrm{a}} \mathrm{s}, \mathbf{3 3}$ was much more stable, whereas 21 decomposed rapidly. Therefore it is evident that $\mathrm{p} K_{\mathrm{a}}$ data alone cannot explain their reactivity. However, the base protonation site for Asp-1-deaza-dAMP (21) is N3 atom whereas N1 for others, this may have a role for the exceptional reactivity of 21. During $\mathrm{pH}-$ metric titration of aspartyl adenine and deazaadenine NPs and their corresponding nucleosides, a significant difference was observed for the CSP of $\mathrm{H} 8$ proton of 21. A shielding effect on $\mathrm{H} 8$ proton (wrong way chemical shift, Figure 4E, S10) was observed during base protonation of 21, while usual deshielding effect on the H8 proton (Figure 4D, S11) occurred in all other aspartyl adenine and deazaadenine NPs and nucleosides (even for 2'-deoxy-1deazaadenosine). This suggests that due to protonation the environment of the purine ring of $\mathbf{2 1}$ differs from that of aspartyl adenine and 3/7-deazaadenine NPs, possibly indicating a conformational change of the nucleobase, positioning the H8 of 21 away from the deshielding zone of phosphate group.

Possible mechanism of acid-catalysed $\mathrm{P}-\mathrm{N}$ and $\mathrm{P}-\mathrm{O}$ bond hydrolysis: In the acid catalysed hydrolysis of aaNPs, only $\mathrm{P}-\mathrm{N}$ bond hydrolysis for $\beta$-Ala NPs, simultaneous $\mathrm{P}-\mathrm{N}$ and $\mathrm{P}-\mathrm{O}$ cleavage for Asp and Gly NPs (except 5), and for Asp-1-deaza-dAMP only $\mathrm{P}-\mathrm{O}$ bond hydrolysis was observed. This suggests the involvement of at least two independent reaction mechanisms for $\mathrm{P}-\mathrm{N}$ and $\mathrm{P}-\mathrm{O}$ bond hydrolysis which are operating together or independently depending on the molecular nature of aaNPs. In order to explain the hydrolysis pathways we propose reaction mechanism for $\mathrm{P}-\mathrm{N}$ and $\mathrm{P}-\mathrm{O}$ bond hydrolysis based on the reported literatures.

The possible protonated forms of aaNP and their tautomeric equilibrium at different solution $\mathrm{pH}$ are shown in Scheme 2A. The phosphoramidate monoanion (IV) in principle can be protonated either at the amide nitrogen or at the phosphoryl oxygen. Experimental evidence in the favour of $\mathrm{N}$-protonation ( $v s . \mathrm{O}$ protonation) in solution is reported ${ }^{[25,30]}$, however, some authors provided theoretical arguments ${ }^{[23,31]}$ for partial $O$-protonation and for the existence of an equilibrium between $N$ and $O$-protonated forms.

The acid catalysed $\mathrm{P}-\mathrm{N}$ bond hydrolysis of various nonnucleosidic phosphoramidates has been documented previously ${ }^{[15,23}$, 32] and recently it has been discussed in the perspective of nucleoside phosphoramidates. ${ }^{[13,31,33,34]} \mathrm{P}-\mathrm{N}$ bond hydrolysis most probably proceeds through the $N$-protonated zwitterionic form (III), since water attack will be favoured in the zwitterionic phosphate than the monoanionic form, and the leaving group can depart as a neutral amine. The mechanism of $\mathrm{P}-\mathrm{N}$ bond hydrolysis (Scheme 2B) possibly involves a "loose (or hazy)" $\mathrm{S}_{\mathrm{N}}$ 2-like transition state (TS) in which the $\mathrm{P}-\mathrm{N}$ bond cleavage is far more advanced than $\mathrm{O}-$ $\mathrm{P}$ bond formation i.e. both the entering and the leaving groups are present in the transition state ${ }^{[25,32,35]}$, representing a borderline case between an associative and dissociative mechanism.

The Asp and Gly NPs are also (partly or fully) hydrolysed by $\mathrm{P}-\mathrm{O}$ bond cleavage, triggered by the intramolecular attack of $\alpha$ carboxyl group to phosphate centre. A plausible $\mathrm{P}-\mathrm{O}$ bond hydrolysis mechanism is depicted in Scheme 2C. The mechanism possibly involves the $O$-protonated tautomer (I) since attack of neutral phosphate by $\alpha$-carboxyl oxyanion will be more favourable. 
(A)

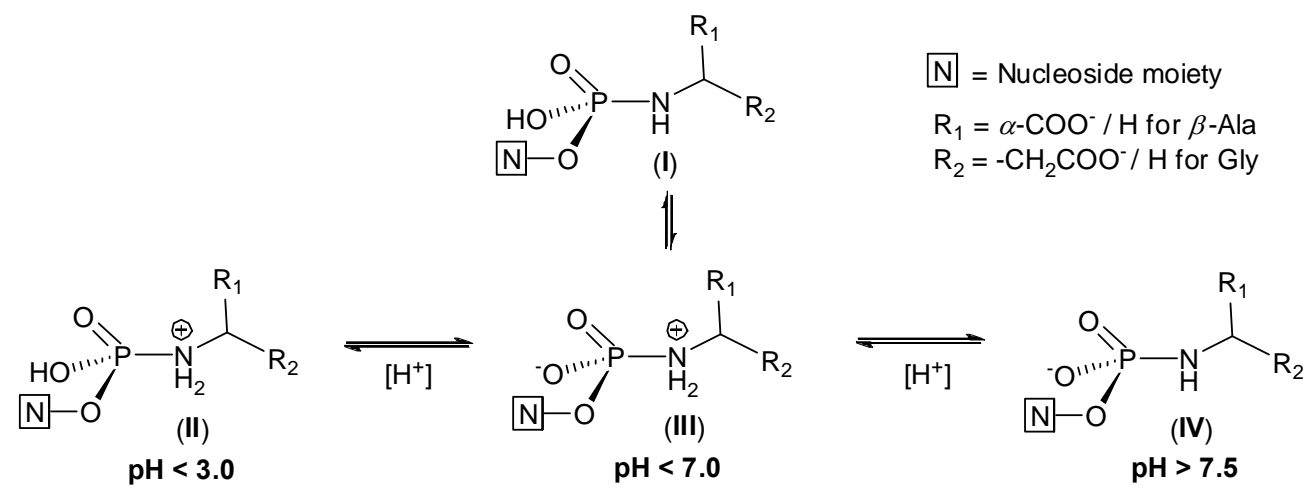

(B)<smiles>[R]C([R])NP(=O)([O-])O[Na]</smiles>

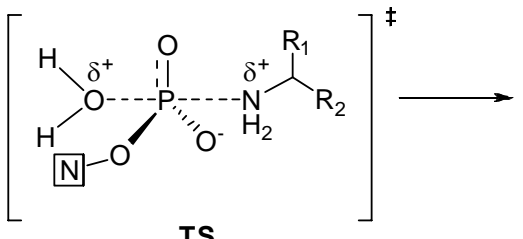<smiles>[R]C([NH3+])[18OH]</smiles>

(C)<smiles>[R2]C1NP(=O)(O)CC1(O)OC(=O)[O-]</smiles>

(I)<smiles>[R2]C(C(=O)O)[R](N)(=O)OP(=O)([O-])OC1CC1</smiles>

$\mathrm{pH}<7.0$<smiles>[R2]C(NP(=O)([O-])OC1CC1)C(=O)OC1CC1</smiles>

$\mathrm{pH}>7.5$

$\downarrow\left[\mathrm{H}^{+}\right]$<smiles>[R2]C1N[P+](C)(O)(O)(OC2CC2)OC(=O)[C@H]1O</smiles><smiles>[R2][C@H]1NP(=O)(O)OC1=O</smiles><smiles>[R2]C([18OH])C(=O)O[Na]</smiles>

Phosphorane Intermediate

Scheme 2: (A) Possible protonated forms of nucleoside phosphoramidates and their tautomers based on experimental $\mathrm{p} K_{\mathrm{a}}$ and solution $\mathrm{pH}$. Possible mechanism for the acid-catalysed hydrolysis of amino acid nucleoside phosphoramidates, (B) Mechanism for $\mathrm{P}-\mathrm{N}$ bond hydrolysis, (C) Mechanism for $\mathrm{P}-\mathrm{O}$ bond hydrolysis.

However, recently it has been shown that neighbouring carboxylate anion can also attack monoanionic phosphate group by NMR of ${ }^{18} \mathrm{O}$ labelled compound. ${ }^{[36]}$ Initial attack of the $\alpha$-carboxyl oxyanion on phosphorus takes place along with concomitant transfer of proton from the bulk hydronium ion to the phosphoryl oxyanion. This gives rise to a penta-coordinated five-membered cyclic trigonal bipyramidal (tbp) phosphorane intermediate where the carboxy oxygen as the entering nucleophile takes an apical position, ${ }^{[13]}$ and hence, the nitrogen atom as a member of the five membered ring is forced to remain in equatorial position ${ }^{[37]}$. The $5^{\prime}-O$ linked nucleoside moiety occupies the remaining apical position and hence departs with a proton transfer to the $5^{\prime}$-oxygen. In contrast to a protonated amine leaving group ( $\mathrm{P}-\mathrm{N}$ hydrolysis), a nucleoside is expected to be a rather bad leaving group ( $\mathrm{P}-\mathrm{O}$ hydrolysis) since it is difficult to protonate $5^{\prime}$-oxygen in study condition (pD 5-7). For the removal of the neutral nucleoside leaving group a proton transfer is necessary. Departure of the nucleoside yields a cyclic phosphoramidate which is anticipated to be hydrolytically much 
unstable at $70{ }^{\circ} \mathrm{C}$ and hydrolysed subsequently to amino acid and inorganic phosphate.

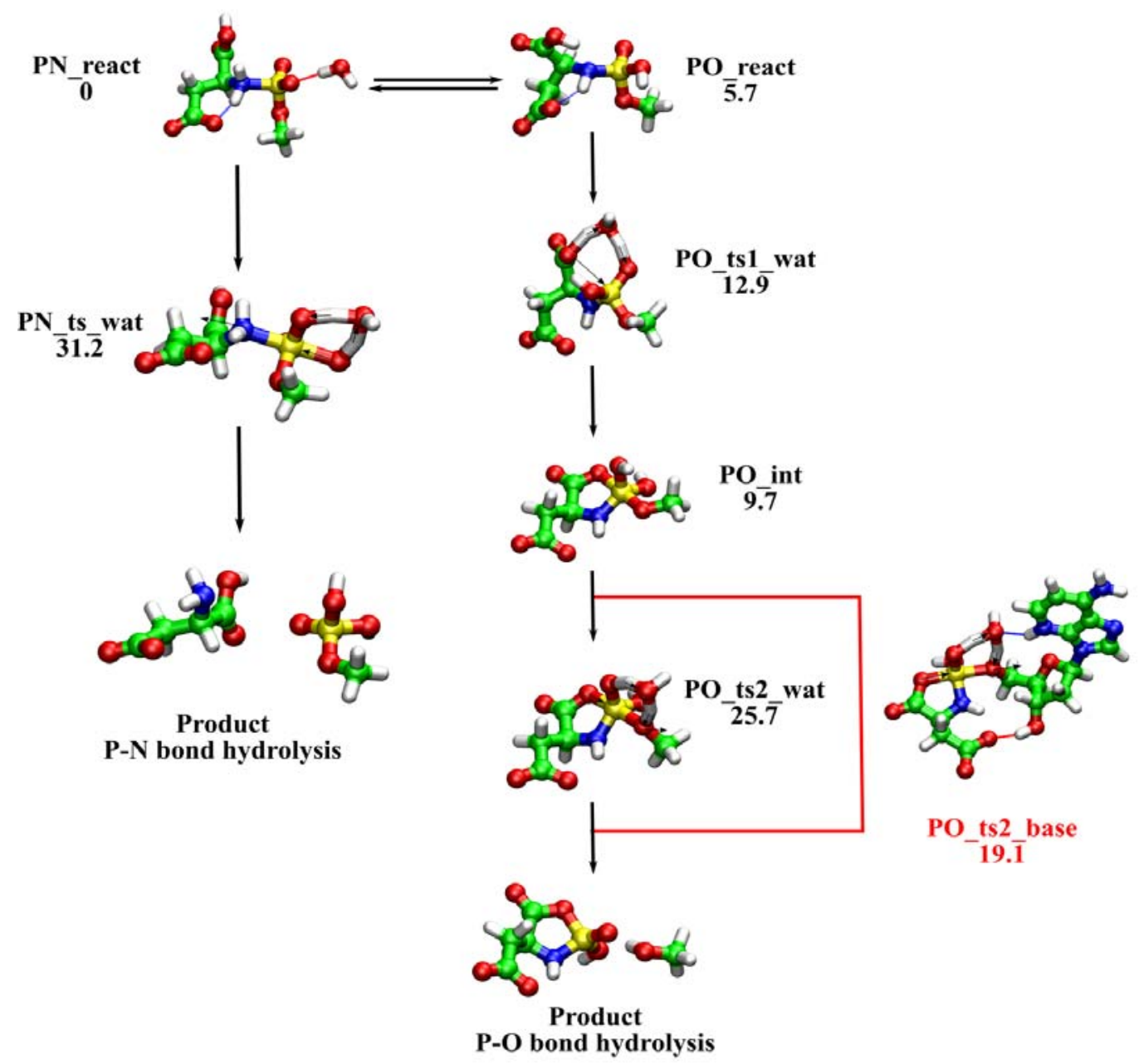

Figure 5: Overview of the mechanisms with the lowest energy barrier for $\mathrm{P}-\mathrm{O}$ and $\mathrm{P}-\mathrm{N}$ bond hydrolysis. The red line indicates the role of the 1-deazaadenine base. All energy values are in $\mathrm{kcal} / \mathrm{mol}$.

\section{Influence of amino acid and nucleobase from theoretical perspective:}

(A) Amino acid: The influence of the amino acid was studied using the model compound, asp-mono-methyl-phosphate shown in Figure 5. Here the nucleoside part is replaced by a methyl group and only the effect of the carboxyl groups is investigated. Earlier work ${ }^{[34]}$ on mono-methyl phosphate pointed out that the barrier for hydrolysis of the $\mathrm{P}-\mathrm{O}$ bond was about $40 \mathrm{kcal} / \mathrm{mol}$. In asp-mono-methylphosphate the $\alpha$ - and $\beta$-carboxyl groups offer the possibility for intramolecular catalysis. As shown in Figure 5, the barrier is reduced to $25.7 \mathrm{kcal} / \mathrm{mol}$ when a 5 -membered ring is formed by the attack of $\alpha$-carboxyl group on phosphorus (Scheme 2C). Formation of a 6-membered ring by the attack of $\beta$-carboxyl group is 5 $\mathrm{kcal} / \mathrm{mol}$ higher in energy. Catalytic water molecules are of major importance here (Figure 5), the highest barrier is $25.7 \mathrm{kcal} / \mathrm{mol}$ for PO_ts2_wat, when the proton transfer doesn't occur via a water molecule the barrier of this step is $35.9 \mathrm{kcal} / \mathrm{mol}$. The most stable reactant is the zwitterionic form with the nitrogen protonated and the phosphate deprotonated, but since the cyclic intermediate (having pentavalent phosphorus with protonated nitrogen) for $\mathrm{P}-\mathrm{O}$ bond hydrolysis is not stable with this tautomer the reaction must occur via the tautomer I (Scheme 2C) with the proton on the phosphate group. There is an energy penalty of $5.7 \mathrm{kcal} / \mathrm{mol}$ for this tautomerisation. The $\beta$-carboxyl group might have an enhancing entropic effect via structural role, as can be seen in PO_ts2_base, where a hydrogen bridge between the 3'-hydroxyl group of the sugar moiety and/or N-H group of Asp and $\beta$-carboxyl group places the $\alpha$ carboxyl in the correct position for attack on phosphorus.

The cleavage of the $\mathrm{P}-\mathrm{N}$ bond occurs via the most stable tautomer III (Scheme 2B) and is not influenced by the amino acid since it is geometrically impossible to form a cyclic 5 -membered intermediate with nitrogen and the carboxyl group of the amino acid at the apical positions. The $\mathrm{P}-\mathrm{N}$ bond hydrolysis occurs via a concerted mechanism where $\mathrm{P}-\mathrm{N}$ bond cleavage and $\mathrm{O}-\mathrm{P}$ bond formation occur simultaneously. First the $N$-protonation prolongs the $\mathrm{P}-\mathrm{N}$ bond from $1.6 \AA$ to $1.81 \AA$ before the formation of the $\mathrm{O}-\mathrm{P}$ 
bond starts. In the transition state ( $\mathrm{PN}$ ts wat) the $\mathrm{P}-\mathrm{N}$ bond is further extended to $2.0 \AA$ with a simultaneous partial formation of the $\mathrm{O}-\mathrm{P}$ bond $(1.99 \AA)$. Finally moving from the transition state to the product state the O-P bond is fully formed $(1.75 \AA)$ and the $\mathrm{P}-\mathrm{N}$ bond is cleaved. This is different from the mechanism predicted for $N$-methyl phosphoramidate, ${ }^{[34]}$ where a more dissociative mechanism is preferred. This can be explained by the presence of an extra methyl group on phosphate here, this disfavours the formation of a metaphosphate intermediate.

(B) Nucleobase: Effect of the nucleobase is most pronounced for the 1-deaza analogues. To catalyse the hydrolysis reaction even further the base must reduce the highest barrier which is 25.7 $\mathrm{kcal} / \mathrm{mol}$ for PO_ts2_wat. Calculations for Asp-1-deaza-dAMP (21) show that when the base is protonated at N3 (expected for 1deazaadenine), the syn and anti conformations of the base are equal in free energy. This can be favoured by the possibility of the base to form a hydrogen bond between $\mathrm{N} 3-\mathrm{H}$ and the phosphate group. Hydrogen bonding between the base and the catalytic water molecule as shown in PO_ts2 base (Figure 5) reduces the barrier for $\mathrm{P}-\mathrm{O}$ cleavage by $6 . \overline{6} \mathrm{kcal} / \mathrm{mol}$. Although, there is also an alternative possibility with slightly higher in energy where protonated N3 can directly be involved in hydrogen bonding with the $5^{\prime}-O$ of nucleoside part thereby effectively delivering a proton to the nucleoside leaving group. These together may explain the increased rate of $\mathrm{P}-\mathrm{O}$ bond hydrolysis for Asp-1-deaza-dAMP compared to Asp-dAMP, Asp-7-deaza-dAMP and Asp-3-deazadAMP.

Conformational study by NMR: To investigate the conformational role in the kinetics and mechanism of $\mathrm{P}-\mathrm{O}$ bond hydrolysis as suggested by molecular modelling, a comparative solution conformational study for Asp NPs containing adenine and deazaadenines was performed in acidic and basic solution (pD 5 and $8)$.

The deoxyribose sugar ring of all the conjugates adopts typical S-type (South, 2'-endo) puckering in $\mathrm{D}_{2} \mathrm{O}$ irrespective of solution $\mathrm{pD}$ as indicated by the appearance of a triplet $\mathrm{H} 1^{\prime}$ peak (Figure S12A, ${ }^{3} J_{\mathrm{H}^{\prime}-\mathrm{H} 2^{\prime} / \mathrm{H} 2^{\prime \prime}}=7 \mathrm{~Hz}$ ). In all Asp NPs, the nucleotide part adopts an orientation (in both $\mathrm{pD}$ ) as observed in the nucleotide residue of regular DNA duplex. The ${ }^{3} J_{\mathrm{C} 4^{\prime}-\mathrm{P}}(9.3 \mathrm{~Hz})$ coupling was determined from ${ }^{1} \mathrm{H}$ decoupled carbon spectrum indicating the $\beta$ (C4'-C5'-O5'P) torsion angle within the trans region. ${ }^{[38]}$ Moreover, a small ${ }^{4} J_{\mathrm{H} 4^{\prime}-\mathrm{P}}$ coupling $(\sim 1-2 \mathrm{~Hz})$ was detected by comparing ${ }^{31} \mathrm{P}$ coupled and decoupled H4' proton peak (Figure S12B). This was further confirmed by the appearance of a small cross-peak in the ${ }^{1} \mathrm{H}^{31} \mathrm{P}$ HETCOR spectra (Figure S12C). Observation of this long range coupling $\left({ }^{4} J_{\mathrm{H}^{\prime}-\mathrm{P}}\right)$ indicated a planar $\mathrm{W}$-shaped conformation of the molecular fragment $\mathrm{H} 4^{\prime}-\mathrm{C} 4{ }^{\prime}-\mathrm{C} 5{ }^{\prime}-\mathrm{O} 5{ }^{\prime}-\mathrm{P}$ with $\beta$ torsion in anti region and $\gamma\left(\mathrm{C}^{\prime}-\mathrm{C} 4^{\prime}-\mathrm{C} 5^{\prime}-\mathrm{O} 5^{\prime}\right)$ in gauche + region. ${ }^{[38]}$ Aspartyl moiety in all these analogues adopts similar conformation in both $\mathrm{pD}$ as no significant change in ${ }^{3} J$ homo and hetero nuclear couplings was observed (Table S2). Aspartyl moiety was found to have proximity to sugar residue irrespective of the solution $\mathrm{pD}$ since $\mathrm{NOE}$ correlation between $\mathrm{H}^{\prime}$ and $\mathrm{H} \alpha / \mathrm{H} \beta$ of Asp was observed in the ROESY spectra (Figure S13). This is somewhat in agreement with the proposed molecular model, where $\mathrm{H}$-bonding between $\beta-\mathrm{COOH}$ and $3^{\prime}-\mathrm{OH}$ was shown.

In order to characterise the existence of any syn conformation of nucleobase as suggested by molecular modelling study, ${ }^{1} \mathrm{H}$ coupled ${ }^{13} \mathrm{C},{ }^{1} \mathrm{H}-{ }^{1} \mathrm{H}$ ROESY and ${ }^{1} \mathrm{H}-{ }^{31} \mathrm{P}$ HOESY experiments were performed. The glycosyl torsion angle $\chi$ was defined by ${ }^{3} J_{\mathrm{H}^{\prime}-\mathrm{C} 4}$ (and $\left.{ }^{3} J_{\mathrm{H} 1^{\prime}-\mathrm{C} 8}\right)$ coupling and based on ${ }^{1} \mathrm{H}-{ }^{1} \mathrm{H}$ and ${ }^{1} \mathrm{H}-{ }^{31} \mathrm{P}$ NOE interactions in order to discriminate between syn and anti conformation of nucleobase. The ${ }^{3} J_{\mathrm{H} 1^{\prime}-\mathrm{C} 4}$ coupling of $c a .2 \mathrm{~Hz}$ for Asp-dAMP (1) was observed in both $\mathrm{pD}$, indicating predominant anti orientation (Figure S14B). ${ }^{[38]}$ The anti conformation of nucleobase was further supported by the observed ${ }^{1} \mathrm{H}-{ }^{1} \mathrm{H}$ NOE cross-peaks (Figure S14C).

However, in case of Asp-1-deaza-dAMP (21), a significant conformational difference in nucleobase orientation was observed in acidic and basic solution. In basic solution ( $\mathrm{pD} 8$ ), the ${ }^{3} J_{\mathrm{H}^{\prime}-\mathrm{C} 4}$ coupling was $c a .2 .0 \mathrm{~Hz}$, indicating predominant anti conformation of the nucleobase (Figure 6A), further supported by the observed NOE cross-peaks. The H8 proton showed cross-peaks with sugar and aspartyl protons, whereas $\mathrm{H} 2$ proton does not show any correlation (Figure 6B: Left). Moreover, in the HOESY spectrum, $\mathrm{H} 8$ proton shows correlation with phosphorus, while $\mathrm{H} 2$ does not (Figure 6C: Left). These data clearly indicate that the nucleobase orientation of $\mathbf{2 1}$ in the basic solution is in the anti domain. However, in acidic condition ( $\mathrm{pD} 5$ ), the ${ }^{3} J_{\mathrm{H} 1^{\prime}-\mathrm{C} 4}$ coupling was not possible to determine as the $\mathrm{C} 4$ carbon peak became too broad (Figure 6A), possibly indicating conformational dynamics across glycosyl bond. But from the ROESY and HOESY spectra, the existence of some population of syn conformers were identified as $\mathrm{H} 2$ proton shows cross-peaks in addition to that of $\mathrm{H} 8$ (Figure 6B, C: Right). Nucleobase orientation in $\mathbf{3 2}$ and $\mathbf{3 3}$ was akin to 21, i.e. some population of syn conformers were present in the acidic solution (Figure S15, 16). The change in nucleobase conformation from anti to syn in acidic solution can be rationalised on the basis of possible electrostatic interaction between positively charged pyrimidine ring and negatively charged phosphate and/or carboxylic acid groups.

In acidic solution for deazaadenine containing analogues the syn conformers are detected while not so for adenine analogue. This could be explained on the basis of higher nucleobase $\mathrm{p} K_{\mathrm{a}}$ of deazaadenines compared to adenine, where existence of more protonated forms is expected in the acidic solution. As discussed earlier, both the kinetic data and molecular modelling suggest the involvement of protonated $\mathrm{N} 3$ atom in catalysing $\mathrm{P}-\mathrm{O}$ bond hydrolysis. The protonated $\mathrm{N} 3$ atom of adenine and 1/7deazaadenine might be involved in the H-bonding directly or via water molecule with 5 '-O of aaNPs, where it can act in stabilising the TS of $\mathrm{P}-\mathrm{O}$ bond hydrolysis or by effectively delivering a proton to the nucleoside leaving group via rare syn conformation. Based on protonation site of nucleobase, the N3 protonated form of Asp-1deaza-dAMP is expected to be more abundant, while for Asp-7deaza-dAMP and Asp-dAMP the N3 protonated form is rare as N1 is found to be the predominant protonation site whereas for Asp-3deaza-dAMP there is no possibility for N3 protonation. This may explain in general the order of reactivity of nucleobase in catalysing $\mathrm{P}-\mathrm{O}$ bond hydrolysis of Asp and Gly NPs. 

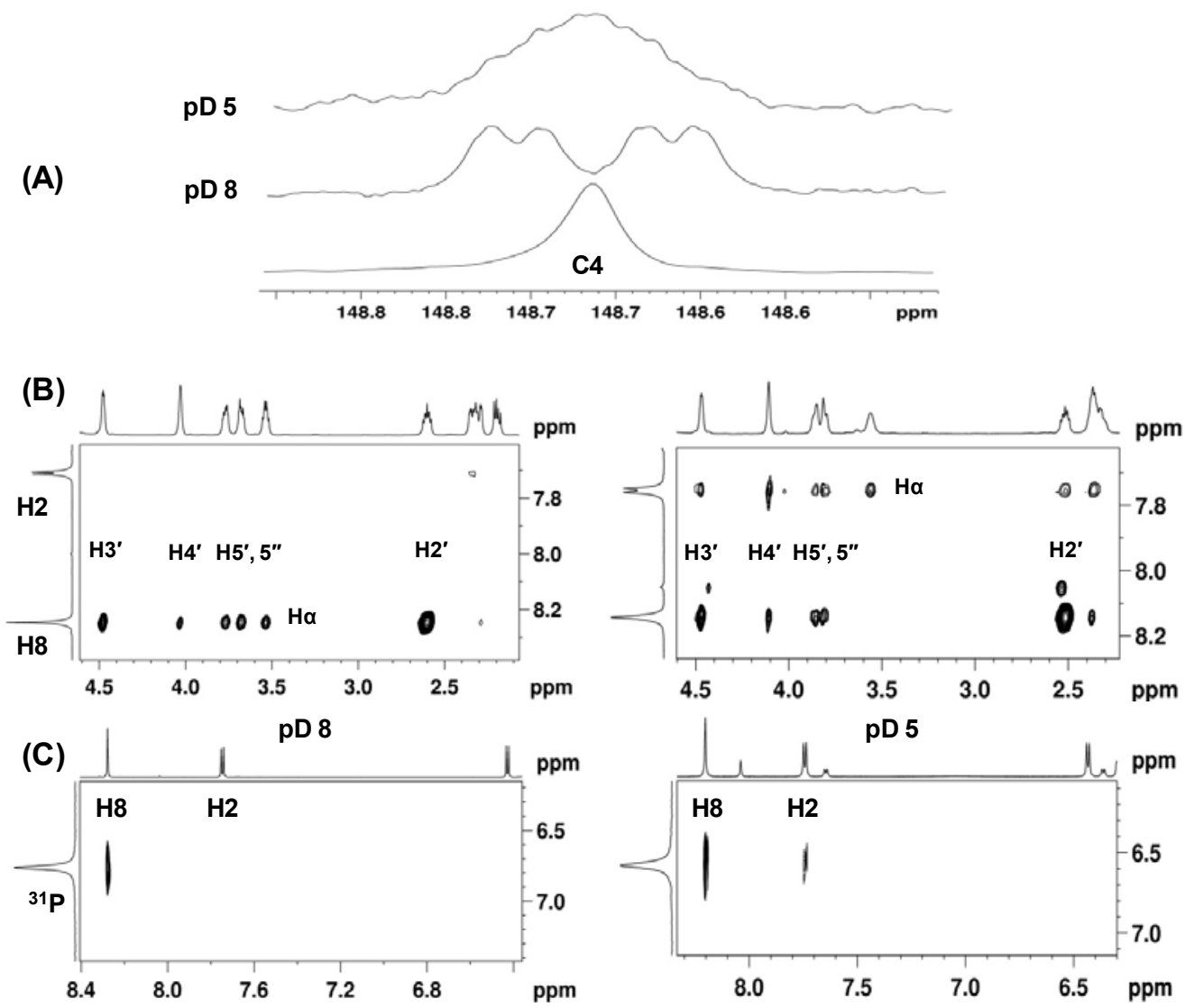

Figure 6: (A) ${ }^{1} \mathrm{H}$ coupled ${ }^{13} \mathrm{C}$ spectra of Asp-1-deaza-dAMP (21), showing the splitting pattern of $\mathrm{C} 4$ carbon peak at pD 5 and 8 ; indicating the change of ${ }^{3} J_{\mathrm{H} 1^{\prime}-\mathrm{C} 4}$ coupling due to conformational change of nucleobase in basic and acidic solution. (B) Expansion of ROESY spectrum of 21 (Left: at pD 8), showing NOE cross-peaks between H8 and sugar protons and $\mathrm{H} \alpha$ of aspartyl group, whereas, $\mathrm{H} 2$ shows no NOE cross-peaks with any protons, indicating predominant 'anti-like' conformation of the nucleobase moiety in basic solution, while at pD 5 (Right), $\mathrm{H} 2$ proton shows NOE cross-peaks with sugar and aspartyl protons in addition to that of $\mathrm{H} 8$ proton, indicating the existence of some population of 'syn' conformers in acidic condition. (C) Expansion of ${ }^{1} \mathrm{H}^{-31} \mathrm{P}$ HOESY spectrum of 21 (Left: at pD 8), depicting NOE cross-peak between H8 and ${ }^{31} \mathrm{P}$ where no cross-peak appeared between $\mathrm{H} 2$ and ${ }^{31} \mathrm{P}$, while at $\mathrm{pD} 5$ (Right), a small cross-peak appeared between $\mathrm{H} 2$ and ${ }^{31} \mathrm{P}$ along with $\mathrm{H} 8$ proton, indicating a proximity between $\mathrm{H} 2$ proton and phosphorus in acidic condition. All spectra were recorded at $10{ }^{\circ} \mathrm{C}$ in $\mathrm{D}_{2} \mathrm{O}$.

\section{Conclusion}

Amino acid nucleoside phosphoramidates can be used in the antiviral prodrug strategy as well as direct substrates for viral polymerases. The 'prodrug' approach relies on the successful delivery of the nucleotide moiety in the cell either by chemical or by enzymatic hydrolysis of the nucleoside phosphoramidate by selective $\mathrm{P}-\mathrm{N}$ bond cleavage. When functioning as direct substrate for polymerase, the phosphoramidate should be stable enough and survive from the unwanted $\mathrm{P}-\mathrm{N}$ and $\mathrm{P}-\mathrm{O}$ bond cleavage before it reaches the enzyme's pocket. In both of these approaches an unnecessary release of nucleoside by means of $\mathrm{P}-\mathrm{O}$ bond cleavage should be avoided. To establish the aforementioned criteria, it is essential to identify the determinants that govern selectivity for $\mathrm{P}$ $\mathrm{N} / \mathrm{P}-\mathrm{O}$ bond hydrolysis.

In the present study, we attempted to identify the structural factors that modulate the molecule's physico-chemical properties and influence the hydrolysis kinetics and mechanism. The experimental and theoretical studies showed a significant reactivity difference based on the nature of amino acid and nucleobase. The presence of only $\beta$-carboxyl group triggered selective $\mathrm{P}-\mathrm{N}$ bond cleavage whereas the presence of $\alpha$-carboxyl group made $\mathrm{P}-\mathrm{O}$ bond more labile and the lability was enhanced in the presence of an additional $\beta$-carboxyl group. The rate of hydrolysis reaction was further accelerated by adenine or 1/7-deazaadenine base for $\mathrm{P}-\mathrm{O}$ bond hydrolysis. The 1-deazaadenine nucleobase in combination with $\alpha$ - and $\beta$-carboxylic acid groups made the molecule exceptionally prone to $\mathrm{P}-\mathrm{O}$ bond hydrolysis. Kinetic data, molecular modelling and conformational studies suggest the possibility for involvement of protonated $\mathrm{N} 3$ atom of adenine and 1/7deazaadenine in the intramolecular catalysis of $\mathrm{P}-\mathrm{O}$ bond hydrolysis via syn conformation.

Based on the preference $(\mathrm{P}-\mathrm{N} v s . \mathrm{P}-\mathrm{O})$ of hydrolysis it could, for example, be expected that 3-deaza $(\mathrm{P}-\mathrm{N}>\mathrm{P}-\mathrm{O})$ phosphoramidates might favourably deliver nucleoside monophosphates compared to 1/7-deaza's which preferentially deliver nucleosides via chemical degradation. Recently it was shown that 2'-deoxyadenosine-5'-iminodiacetyl phosphoramidate (IDAdAMP, Figure S17A) is an efficient substrate compare to AspdAMP (1) for the HIV-1 RT. ${ }^{[12]}$ Notably its hydrolysis study (Figure S17B) revealed that despite the presence of the two $\alpha$ carboxyl groups it hydrolysed by exclusive $\mathrm{P}-\mathrm{N}$ bond cleavage (Figure S17C, D). This could be due to the increased basicity of the phosphoramidate nitrogen, leading to favourable protonation and release of iminodiacetate by the attack of water molecule. This example and other data from the present study show that property of nucleobase as well as amino acid leaving group have to be considered for explaining $\mathrm{P}-\mathrm{N} / \mathrm{P}-\mathrm{O}$ bond hydrolysis of nucleoside phosphoramidates. 


\section{Experimental Section}

Synthesis and characterization: All detailed synthetic schemes, procedures and molecular characterisation data are provided in the supporting information.

Kinetic study of hydrolytic reaction: Approximately $20 \mathrm{mM}$ sample was prepared in $\mathrm{D}_{2} \mathrm{O}$ and $\mathrm{pD}$ of the sample was adjusted by addition of small volume (few $\mu \mathrm{L}$ ) of $\mathrm{HCl}$ or $\mathrm{NaOH}$ solutions in $\mathrm{D}_{2} \mathrm{O}(0.1 \mathrm{M} / 0.5 \mathrm{M})$. The progress of the reaction was monitored using Bruker Avance II $500 \mathrm{MHz}$ NMR spectrometer and the kinetic cycle was recorded using Bruker Icon NMR automation program. The cycle began with by recording ${ }^{1} \mathrm{H}$ $(\mathrm{NS}=16)$ and ${ }^{31} \mathrm{P}(\mathrm{NS}=128) \mathrm{NMR}$ spectra at $25^{\circ} \mathrm{C}$. Each round of kinetic cycle consisted of a heating step at 40 or $70{ }^{\circ} \mathrm{C}$ for $25 \mathrm{~min}$ inside the NMR instrument, the sample was then cooled down to $25^{\circ} \mathrm{C}$ and ${ }^{1} \mathrm{H}$ and ${ }^{31} \mathrm{P}$ spectra were recorded. The peaks appeared in ${ }^{1} \mathrm{H}$ and ${ }^{31} \mathrm{P}$ NMR spectra were integrated and the extent of reaction (\%) was calculated from the peak integral. Rate constants were determined by plotting concentration (\%) vs. time (min) and fitting the data points to an exponential decay. Reproducibility of the kinetic experiments was verified by repeating the hydrolysis study for compound $\mathbf{1}$ and $\mathbf{2 1}$ twice. No significant discrepancy in the rate constants was observed. Average rate constant and SEM were calculated by considering both disappearances of the ${ }^{1} \mathrm{H}$ and ${ }^{31} \mathrm{P}$ peaks of parent aaNP and the appearances of the products peaks in the ${ }^{1} \mathrm{H}$ and ${ }^{31} \mathrm{P}$ spectra wherever feasible. The products formed after hydrolysis were identified by ${ }^{1} \mathrm{H}_{-}{ }^{31} \mathrm{P}$ TOCSY ${ }^{[39]}$, acquired with 64 scans, 2048 data points in the proton dimension $\left(t_{2}\right)$ and 128 increments in the phosphorus dimension $\left(t_{1}\right)$ over sweep width of 10 and $40 \mathrm{ppm}$ respectively. The residual HOD peak was suppressed by low power on resonance presaturation.

$\mathbf{p} K_{\mathrm{a}}$ determination by NMR titration: Samples were dissolved in $0.5 \mathrm{~mL}$ of $\mathrm{D}_{2} \mathrm{O}$ and the sample's $\mathrm{pD}$ was adjusted directly inside the NMR tube. $\mathrm{pD}$ was measured at room temperature by using Hamilton SPINTRODE electrode. ${ }^{1} \mathrm{H}$ and ${ }^{31} \mathrm{P}$ NMR spectra were recorded at $25{ }^{\circ} \mathrm{C}$ in each $\mathrm{pH}$ point using 32 and 64 scans respectively. The $\mathrm{p} K_{\mathrm{a}}$ of phosphoramidate $\left({ }^{15} \mathrm{~N}\right.$ labelled 1 and 21) nitrogen was determined by monitoring ${ }^{15} \mathrm{~N}$ chemical shift using ${ }^{1} \mathrm{H}_{-}{ }^{15} \mathrm{~N}$ HSQC (long range) experiments on Bruker Avance II 600 $\mathrm{MHz}$ spectrometer. All ${ }^{1} \mathrm{H}^{-15} \mathrm{~N}$ HSQC spectra in the $\mathrm{pH}$-metric titration were recorded with sensitivity enhancement and gradient coherence selection for 8 scans, 128/2048 complex data points, $100 / 10 \mathrm{ppm}$ spectral width in $t_{1}$ and $t_{2}$ respectively. The $\mathrm{pH}$ titration studies were done over a $\mathrm{pD}$ range of $(1.5<\mathrm{pD}<12)$. The $\mathrm{pH}$ values were obtained using equation: $\mathrm{pH}=\mathrm{pD}-0.4{ }^{[40]}$ The $\mathrm{p} K_{\mathrm{a}}$ determination is based on the linear regression analysis of the Hill plot ${ }^{[41]}$ using the equation: $\mathrm{pH}=\log [(1-\alpha) / \alpha]+\mathrm{p} K_{\mathrm{a}}$, where $\alpha$ represents fraction of the protonated species. The value of $\alpha$ is calculated from the change of chemical shift relative to the neutral state at a given $\mathrm{pH}$ divided by the total change in chemical shift between neutral and fully protonated state.

Determination of protonation sites: To determine the protonation site of the nucleobase, $\mathrm{pH}$ dependent ${ }^{13} \mathrm{C}$ chemical shifts were monitored using ${ }^{1} \mathrm{H}-{ }^{13} \mathrm{C}$ HSQC and ${ }^{1} \mathrm{H}-{ }^{13} \mathrm{C}$ HMBC NMR. ${ }^{1} \mathrm{H}-{ }^{13} \mathrm{C}$ HSQC spectra were recorded with sensitivity enhancement and gradient coherence selection. To measure ${ }^{1} \mathrm{H}-{ }^{13} \mathrm{C}$ correlations of only the nucleobase part, ${ }^{1} J_{\mathrm{CH}}$ was set to $180 \mathrm{~Hz}$ and 4 scans, $128 / 2048$ complex data points and $80 / 10 \mathrm{ppm}$ spectral width in $t_{1}$ and $t_{2}$ were used respectively. ${ }^{1} \mathrm{H}-{ }^{13} \mathrm{C}$ HMBC were measured with 4 scans and 128/ 2048 complex data points and 100/10 ppm spectral widths in $t_{1}$ and $t_{2}$ respectively. Delays were optimized for transfer in nucleobases using ${ }^{1} J_{\mathrm{CH}}=145 \mathrm{~Hz}$ in the low pass filter and ${ }^{3} J_{\mathrm{CH}}=8 \mathrm{~Hz}$ for long range correlations.

Theoretical calculations: All calculations were performed using the Gaussian 09 package ${ }^{[42]}$ Visualization was done with VMD ${ }^{[43]}$ The structures were optimized with the B3LYP method ${ }^{[44]}$ with DGDZVP ${ }^{[45]}$ basis set. Solvation corrections using continuum solvent were performed during the optimization process using PCM. ${ }^{[46]}$ Every stationary point was checked by frequency analysis. ZPE corrections using B3LYP were scaled ${ }^{[47]}$ with a factor of 0.9877 .

Conformational studies by NMR: $1 \mathrm{D}^{31} \mathrm{P}$ coupled/decoupled ${ }^{1} \mathrm{H}$ spectra were recorded with 32 scans and $66 \mathrm{k}$ FIDs at $25{ }^{\circ} \mathrm{C}$. Proton coupled $1 \mathrm{D}{ }^{13} \mathrm{C}$ spectra with gated ${ }^{1} \mathrm{H}$ decoupling were acquired using 1024 scans with spectral width of $70 \mathrm{ppm}$ and $100 \mathrm{k}$ FIDs. The ${ }^{1} \mathrm{H}_{-}{ }^{31} \mathrm{P}$ HETCOR ${ }^{[48]}$ spectrum was acquired at $25{ }^{\circ} \mathrm{C}$ with 128 scans, 2048 data points in the ${ }^{1} \mathrm{H}$ dimension $\left(t_{2}\right)$ and 512 increments in the ${ }^{31} \mathrm{P}$ dimension $\left(t_{1}\right)$ over spectral width of 3500 and $4050 \mathrm{~Hz}$ respectively. The ROESY ${ }^{[49]}$ experiments in $\mathrm{D}_{2} \mathrm{O}$ (ROESY-spin lock pulse $=300 \mathrm{~ms}$ ) were performed at $10{ }^{\circ} \mathrm{C}$ with a sweep width of 10 ppm in both dimensions, 64 scans, 2048 data points in $t_{2}$ and 512 FIDs in $t_{1}$. All above experiments were repeated in both acidic $(\mathrm{pD}=5.0)$ and basic solution $(\mathrm{pD}=8.0) .{ }^{1} \mathrm{H}-$ ${ }^{31} \mathrm{P} 2 \mathrm{D}$ hetero-nuclear NOE (HOESY) experiments ${ }^{[50]}$ were performed using Bruker pulse program hoesyph. The WALTZ-65 composite pulse sequence for phosphorus decoupling $\left({ }^{1} \mathrm{H}\right.$ as observed nuclei) during acquisition was used. Spectra were recorded in the phase-sensitive mode using States-TPPI method, with $512\left(t_{1}\right)$ increments and $2 \mathrm{~K}$ $\left(t_{2}\right)$ data points, 64 scans, 16 dummy scans, and $D 1=1.5 \mathrm{~s}$. The mixing time was set to $0.8 \mathrm{~s}$. Sweep widths were 10 and $40 \mathrm{ppm}$ respectively in the ${ }^{1} \mathrm{H}$ and ${ }^{31} \mathrm{P}$ dimension. The data sets were Fourier transformed using shifted sine-bell window function in both dimensions and processed into a $2 \mathrm{~K} \times 0.5 \mathrm{~K}$ matrix without prior zero-filling.

\section{Acknowledgements}

This work was financed by KU Leuven grants GOA, IDO. We are indebted to Prof. Jef Rozenski for providing MS and HRMS data and Prof. Roger Busson for helpful discussion. We thank Luc Baudemprez for NMR technical assistance, Dr. Elisabetta Groaz and Jolien Claessens for technical support and Chantal Biernaux for editorial help.

[1] a) C. Meier, Synlett. 1998, 233-242; b) C. R. Wagner, V. V. Iyer, E. J. McIntee, Med. Res. Rev. 2000, 20, 417-451; c) E. De Clercq, Nat. Rev. Drug Discov. 2002, 1, 13-25; d) E. De Clercq, J. Clin. Virol. 2004, 30, 115-133; e) Y. Mehellou, J. Balzarini, C. McGuigan, ChemMedChem 2009, 4, 1779-1791.

[2] C. L. Freel Meyers, R. F. Borch, J. Med. Chem. 2000, 43, 4319-4327.

[3] C. R. Wagner, S. L. Chang, G. W. Griesgraber, H. Song, E. J. McIntee, C. L. Zimmerman, Nucleosides \& Nucleotides 1999, 18, 913-919.

[4] a) R. N. Hunston, M. Jehangir, A. S. Jones, R. T. Walker, Tetrahedron 1980, 36, 2337-2340; b) A. S. Jones, C. McGuigan, R. T. Walker, J. Balzarini, E. de Clercq, J. Chem. Soc. Perkin Trans. I 1984, 1471-1474; c) A. S. Jones, C. McGuigan, R. T. Walker, J. Chem. Soc. Perkin Trans. I 1985, 199-202.

[5] a) K. G. Devine, C. McGuigan, T. J. O'Connor, S. R. Nicholls, D. Kinchington, AIDS 1990, 4, 371-373; b) D. Cahard, C. McGuigan, J. Balzarini, Mini Rev. Med. Chem. 2004, 4, 371-381.

[6] a) T. W. Abraham, C. R. Wagner, Nucleosides \& Nucleotides 1994, 13, 1891-1903; b) E. J. McIntee, R. P. Remmel, R. F. Schinazi, T. W. Abraham, C. R. Wagner, J. Med. Chem. 1997, 40, 3323-3331.

[7] T. W. Abraham, T. I. Kalman, E. J. McIntee, C. R. Wagner, J. Med. Chem. 1996, 39, 4569-4575.

[8] a) D. Saboulard, L. Naesens, D. Cahard, A. Salgado, R. Pathirana, S. Velazquez, C. McGuigan, E. De Clercq, J. Balzarini, Mol. Pharmacol. 1999, 56, 693-704; b) T. F. Chou, J. Baraniak, R. Kaczmarek, X. Zhou, J. Cheng, B. Ghosh, C. R. Wagner, Mol. Pharm. 2007, 4, 208-217.

[9] a) S. Chang, G. W. Griesgraber, P. J. Southern, C. R. Wagner, J. Med. Chem. 2001, 44, 223-231; b) J. Balzarini, Pharm. World Sci. 1994, 16, 113-126.

[10] O. Adelfinskaya, P. Herdewijn, Angew. Chem. Int. Ed. 2007, 46, 43564358.

[11] a) O. Adelfinskaya, M. Terrazas, M. Froeyen, P. Marliere, K. Nauwelaerts, P. Herdewijn, Nucleic Acids Res. 2007, 35, 5060-5072; b) A. Giraut, N. Dyubankova, X. P. Song, P. Herdewijn, Chembiochem 2009, 10, 22462252 .

[12] A. Giraut, X. P. Song, M. Froeyen, P. Marliere, P. Herdewijn, Nucleic Acids Res. 2010, 38, 2541-2550.

[13] M. Ora, J. Ojanpera, H. Lohnberg, Chem. Eur. J. 2007, 13, 8591-8599.

[14] A. Leisvuori, Y. Aiba, T. Lonnberg, P. Poijarvi-Virta, L. Blatt, L. Beigelman, H. Lonnberg, Org. Biomol. Chem. 2010, 8, 2131-2141.

[15] T. Lonnberg, M. Ora, H. Lonnberg, Mini-Rev. Org. Chem. 2010, 7, 33-43.

[16] T. W. Abraham, T. I. Kalman, E. J. McIntee, C. R. Wagner, J. Med. Chem. 1996, 39, 4569-4575.

[17] I. Dhimitruka, J. SantaLucia, Synlett. 2004, 335-337.

[18] D. D. Boehr, A. R. Farley, F. J. LaRonde, T. R. Murdock, G. D. Wright, J. R. Cox, Biochemistry 2005, 44, 12445-12453.

[19] Yoshikaw.M, T. Kato, Takenish.T, Bull. Chem. Soc. Jpn. 1969, 42, 35053508 .

[20] N. Minakawa, Y. Kawano, S. Murata, N. Inoue, A. Matsuda, Chembiochem 2008, 9, 464-470.

[21] F. Seela, B. Westermann, U. Bindig, J. Chem. Soc. Perkin Trans. I 1988, 697-702.

[22] F. Seela, H. Rosemeyer, S. Fischer, Helv. Chim. Acta. 1990, 73, 1602-1611.

[23] A. W. Garrison, C. E. Boozer, J. Am. Chem. Soc. 1968, 90, 3486-3494. 

Zhao, Chin. J. Chem. 2007, 25, 1559-1562.

$[25]$ J. Rahil, P. Haake, J. Am. Chem. Soc. 1981, 103, 1723-1734.

Z. Z. Chen, B. Tan, Y. M. Li, Y. F. Zhao, Y. F. Tong, J. F. Wang, J. Org. Chem. 2003, 68, 4052-4058.

[27] B. Tan, M. C. Lee, M. Cui, T. Liu, Z. Z. Chen, Y. M. Li, Y. Ju, Y. F. Zhao, K. X. Chen, H. L. Jiang, J. Mol. Struct. (Theochem) 2004, 672, 51-60.

[28] Y.-M. Li, D.-q. Zhang, H.-w. Zhang, G.-J. Ji, Y.-f. Zhao, Bioorg. Chem. 1992, 20, 285-295.

[29] Z. Kazimierczuk, J. A. Vilpo, F. Seela, Helv. Chim. Acta 1992, 75, 22892297.

a) P. Haake, T. Koizumi, Tetrahedron Lett. 1970, 4849-4850; b) K. E. Debruin, A. G. Padilla, D. M. Johnson, Tetrahedron Lett. 1971, 42794280; c) T. Koizumi, P. Haake, J. Am. Chem. Soc. 1973, 95, 8073-8079; d) M. P. Gamcsik, S. M. Ludeman, E. M. Shulmanroskes, I. J. Mclennan, M. E. Colvin, O. M. Colvin, J. Med. Chem. 1993, 36, 3636-3645.

[31] M. Ora, K. Mattila, T. Lonnberg, M. Oivanen, H. Lonnberg, J. Am. Chem. Soc. 2002, 124, 14364-14372.

[32] S. J. Benkovic, E. J. Sampson, J. Am. Chem. Soc. 1971, 93, 4009-4016.

[33] M. Ora, M. Murtola, S. Aho, M. Oivanen, Org. Biomol. Chem. 2004, 2, 593-600.

[34] S. Michielssens, N. Tien Trung, M. Froeyen, P. Herdewijn, M. Tho Nguyen, A. Ceulemans, Phys. Chem. Chem. Phys. 2009, 11, 7274-7285.

[35] W. P. Jencks, M. Gilchrist, J. Am. Chem. Soc. 1964, 86, 1410-1417.

[36] Y. Kajihara, S. Nishigaki, D. Hanzawa, G. Nakanishi, R. Okamoto, N. Yamamoto, Chem. Eur. J. 2011, 17, 7645-7655.

[37] Westheim.Fh, Accounts Chem. Res. 1968, 1, 70-78.
S. S. Wijmenga, B. N. M. van Buuren, Prog. Nucl. Magn. Reson. Spectrosc. 1998, 32, 287-387.

G. W. Kellogg, J. Magn. Reson. 1992, 98, 176-182.

P. K. Glasoe, F. A. Long, J. Phys. Chem. 1960, 64, 188-190.

S. Chatterjee, W. Pathmasiri, O. Plashkevych, D. Honcharenko, O. P. Varghese, M. Maiti, J. Chattopadhyaya, Org. Biomol. Chem. 2006, 4, 1675-1686.

M. J. Frisch, D. J. Fox et al., Gaussian 09, Revision A.1, Gaussian Inc., Wallingford CT, 2009

W. Humphrey, A. Dalke, K. Schulten, J. Mol. Graph. 1996, 14, 33-38. A. D. Becke, J. Chem. Phys. 1993, 98, 5648-5652.

N. Godbout, D. R. Salahub, J. Andzelm, E. Wimmer, Can. J. Chem. 1992, 70, 560-571.

a) B. Mennucci, J. Tomasi, J. Chem. Phys. 1997, 106, 5151-5158; b) S. Miertus, E. Scrocco, J. Tomasi, Chem. Phys. 1981, 55, 117-129. M. P. Andersson, P. Uvdal, J. Phys. Chem. A 2005, 109, 2937-2941. V. Sklenar, H. Miyashiro, G. Zon, H. T. Miles, A. Bax, Febs Lett. 1986, 208, 94-98.

A. Bax, D. G. Davis, J. Magn. Reson. 1985, 63, 207-213.

C. Yu, G. C. Levy, J. Am. Chem. Soc. 1984, 106, 6533-6537. 
Nucleobase in catalysis

Munmun Maiti, Servaas Michielssens, Natalia Dyubankova, Mohitosh Maiti, Eveline Lescrinier, Arnout Ceulemans, Piet Herdewijn*

Influence of Nucleobase and Anchimeric Assistance of Carboxyl Acid Groups in the Hydrolysis of Amino Acid Nucleoside Phosphoramidates

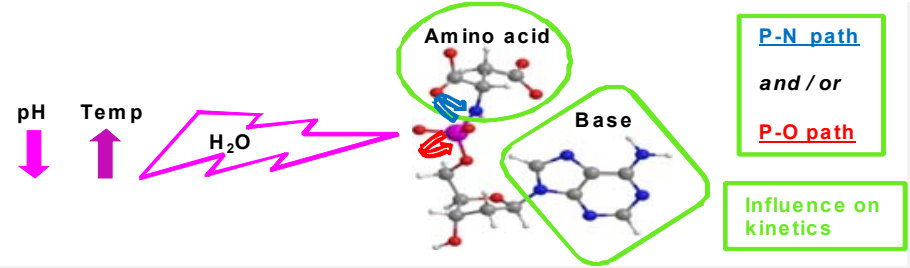

Nucleobase in catalysis: A dual $\mathrm{N} 1 / \mathrm{N} 7$ atom is shown to have a intramolecular catalytic influence is conformational role via protonated demonstrated by the nucleobase and N3 in crucially regulating kinetics carboxyl groups in the chemical and mechanism of nucleotide $(\mathrm{P}-\mathrm{N}$ hydrolysis of amino acid nucleoside path) vs. nucleoside ( $\mathrm{P}-\mathrm{O}$ path) phosphoramidate prodrugs. formation.

Replacement of adenine N3 vs. 


\section{Supporting Information}

\section{Influence of Nucleobase and Anchimeric Assistance of Carboxyl Acid Groups in the Hydrolysis of Amino Acid Nucleoside Phosphoramidates}

Munmun Maiti, ${ }^{[a]}$ Servaas Michielssens, ${ }^{[b]}$ Natalia Dyubankova,${ }^{[a]}$ Mohitosh Maiti, ${ }^{[a]}$ Eveline Lescrinier, ${ }^{[\mathrm{a}]}$ Arnout Ceulemans, ${ }^{[\mathrm{b}]}$ Piet Herdewijn*,[a]

${ }^{[a]}$ Laboratory for Medicinal Chemistry, Rega Institute for Medical Research, Katholieke Universiteit Leuven, Minderbroedersstraat 10, 3000 Leuven, Belgium; ${ }^{[b]}$ Laboratory of Quantum Chemistry, Department of Chemistry and INPAC Institute for Nanoscale Physics and Chemistry, Katholieke Universiteit Leuven, Belgium

*E-mail: Piet.Herdewijn@rega.kuleuven.be, Fax: (+) 3216337340

\section{Contents:}

Figures S1-S17

Page No.

Tables S1 \& S2

Schemes S1-S3

S14

Synthesis and characterisation data

General synthetic procedure for DCC assisted coupling

General protocol for methyl ester deprotection

S18

General synthesis for direct 5'-phosphorylation of deaza-nucleosides

S18

Characterisation data for compounds 1-6 and their intermediates (1a-6a)

S19

Synthesis of 2-deoxy-3,5-di- $O$ - $p$-toluoyl- $\alpha$-D-ribofuranosyl chloride (10)

S20-S23

Synthesis of 1-deazaadenine analogues (21-23)

S23-S24

Synthesis of 7-deazaadenine analogue (32)

S25-S30

Characterisation data for compound (33) 


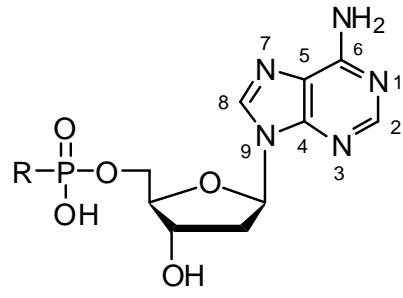

purine numbering

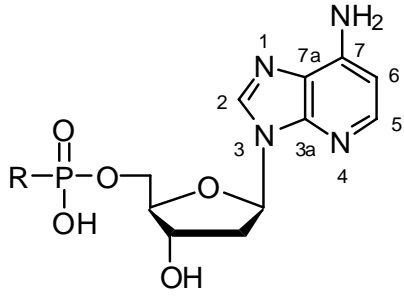

systematic numbering

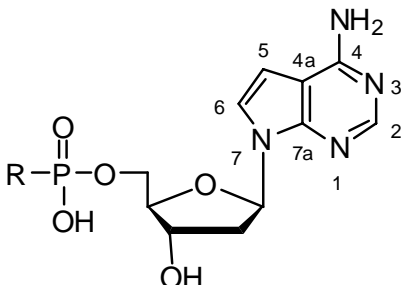

systematic numbering

Figure S1: Purine and systematic numbering of the nucleobase atoms mentioned in the text.

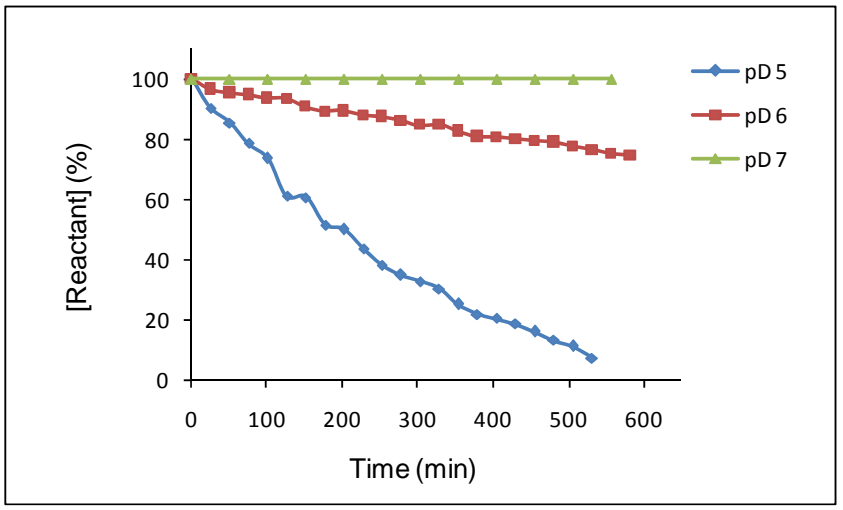

Figure S2: The $\mathrm{pH}$ dependent kinetics of hydrolytic reaction for $\beta$-ala-1-deaza-dAMP (23) at $70{ }^{\circ} \mathrm{C}$. Kinetics at $\mathrm{pD}$ 5 is faster than at $\mathrm{pD} 6$, and at $\mathrm{pD} 7$ compound $\mathbf{2 3}$ is stable within the experimental time. 


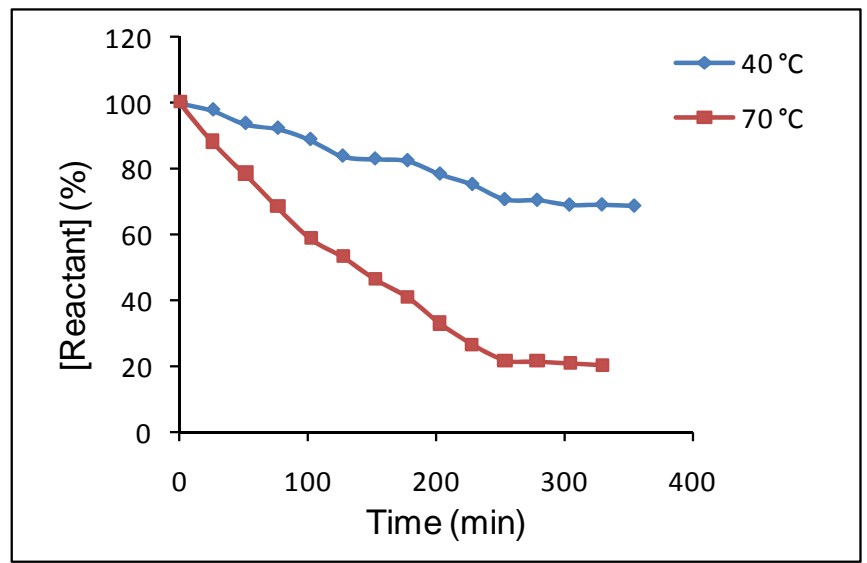

Figure S3: Temperature dependent kinetic profile of the hydrolytic reaction of Asp-1-deaza-dAMP (21) at $40{ }^{\circ} \mathrm{C}$ and $70{ }^{\circ} \mathrm{C}(\mathrm{pD} 7)$.

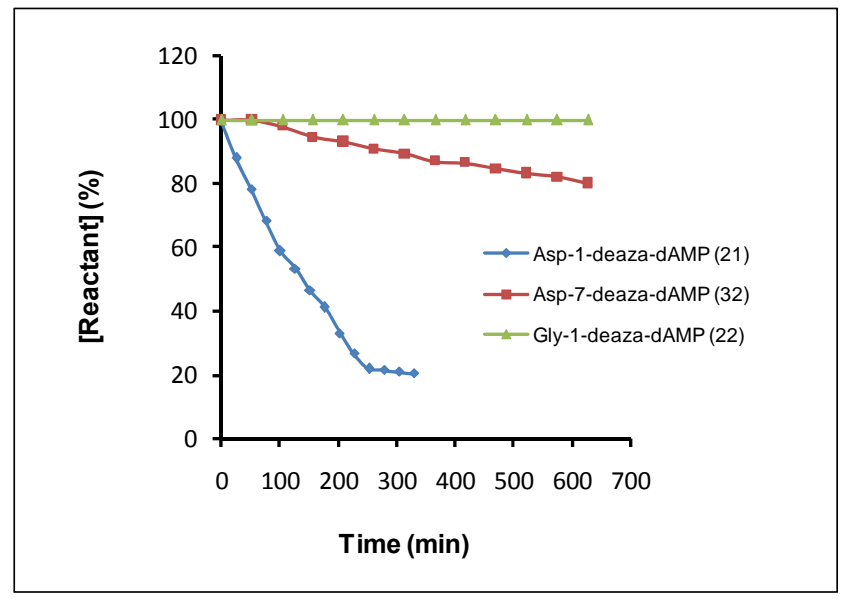

Figure S4: Influence of the amino acid moiety and the nucleobase on the kinetics of hydrolytic reaction. Comparison of $\mathbf{2 1}$ and $\mathbf{2 2}$ indicates the influence of amino acids on hydrolysis rate. Comparison of $\mathbf{2 1}$ and $\mathbf{3 2}$ shows the influence of nucleobase on the rate of hydrolysis. Data are presented for $\mathrm{pD} 7.0\left(70{ }^{\circ} \mathrm{C}\right)$ for these compounds. 
(A)

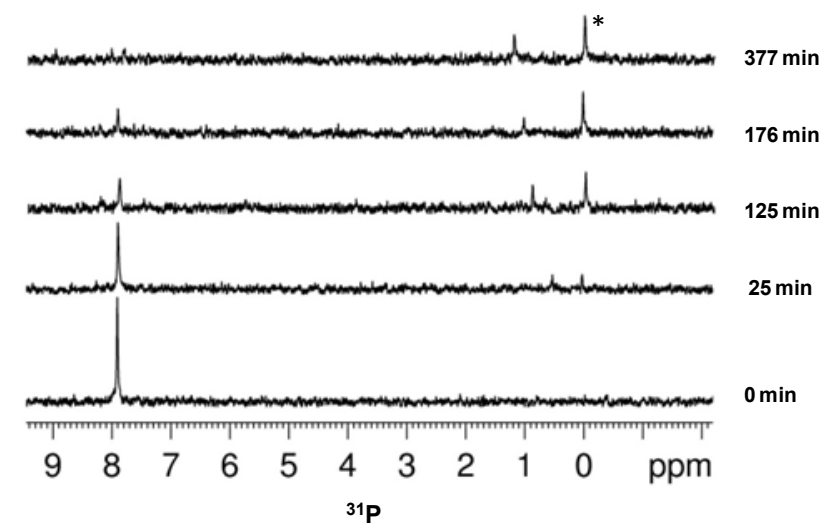

(B)

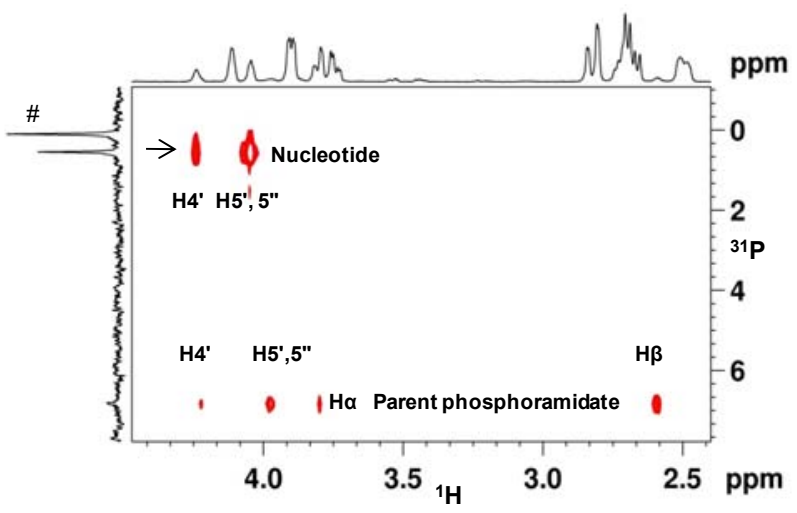

(C)

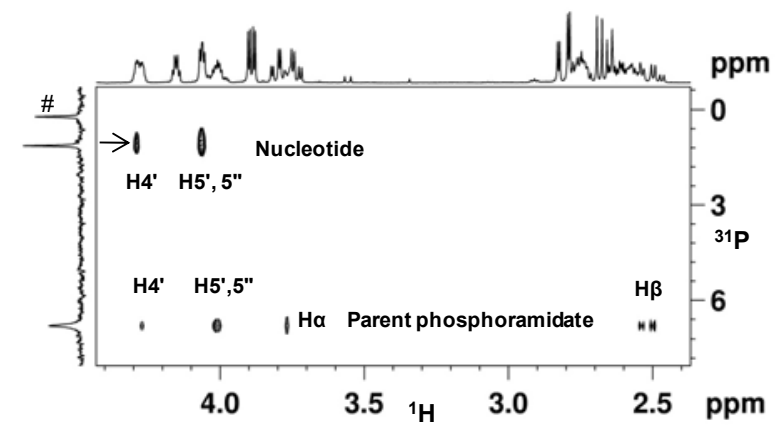

Figure S5: (A) Kinetic profile of the hydrolytic reaction of Gly-1-deaza-dAMP (22) at pD $5.0\left(T=70^{\circ} \mathrm{C}\right)$, depicted by the stack plot of ${ }^{31} \mathrm{P}$ spectra at different time intervals, showing the disappearance of the parent ${ }^{31} \mathrm{P}$ peak $(\sim 8 \mathrm{ppm})$ and gradual increase of two ${ }^{31} \mathrm{P}$ peaks near $0 \mathrm{ppm}$. Asterisk $\left(^{*}\right)$ indicates the free phosphate peak; $(\mathbf{B}){ }^{1} \mathrm{H}-{ }^{31} \mathrm{P}$ TOCSY spectrum of Asp-7-deaza-dAMP (B, Compound 32) and Asp-3-deaza-dAMP (C, Compound 33) after hydrolytic reaction at $\mathrm{pD} 5.0\left(T=70{ }^{\circ} \mathrm{C}\right)$, depicting the formation of inorganic phosphate and the corresponding nucleotide by $\mathrm{P}-\mathrm{O}$ and $\mathrm{P}-\mathrm{N}$ bond cleavage. Nucleotide phosphorus (peak with arrow) showing correlation with $\mathrm{H} 4{ }^{\prime}, \mathrm{H} 5^{\prime}$ and $\mathrm{H} 5{ }^{\prime \prime}$ of sugar moiety, whereas, inorganic phosphate (\#) shows no correlation with any protons. Parent phosphoramidate ${ }^{31} \mathrm{P}$ showing correlation with $\mathrm{H} \alpha$ and $\mathrm{H} \beta$ of aspartyl group along with $\mathrm{H} 4$ ' and $\mathrm{H} 5$ ', 5" of sugar moiety. 


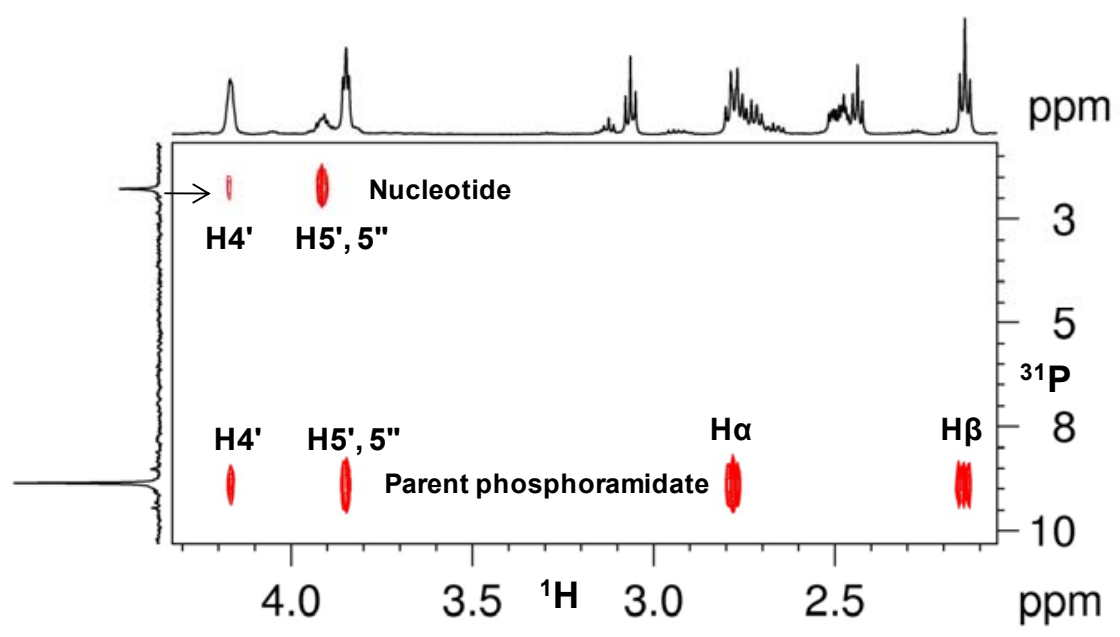

Figure S6: ${ }^{1} \mathrm{H}^{31} \mathrm{P}$ TOCSY spectrum of $\beta$-ala-1-deaza-dAMP (23) after the hydrolysis reaction at pD $6.0\left(70{ }^{\circ} \mathrm{C}\right)$, depicting the formation of corresponding nucleotide by P-N bond cleavage. Nucleotide phosphorus (peak with arrow) shows correlation with $\mathrm{H}^{\prime}$ and $\mathrm{H}^{\prime}$ ', 5" of sugar moiety, whereas, the parent phosphoramidate ${ }^{31} \mathrm{P}$ showing correlation with $\mathrm{H} \alpha$ and $\mathrm{H} \beta$ of alaninyl group along with $\mathrm{H} 4^{\prime}$ and $\mathrm{H} 5^{\prime}, 5^{\prime \prime}$ of the sugar moiety. 


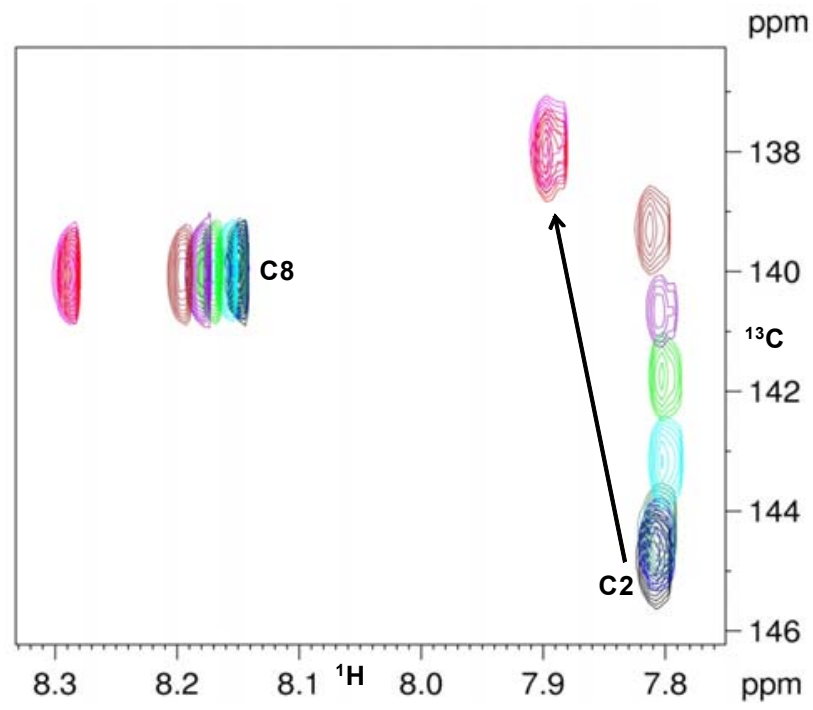

Figure S7: Overlay of ${ }^{1} \mathrm{H}-{ }^{13} \mathrm{C}$ HSQC spectra of $2^{\prime}$-deoxy-1-deazaadenosine (18), depicting chemical shift perturbation (CSP) of $\mathrm{C} 2$ carbon towards up-field in the NMR pH-metric titration from $\mathrm{pD} 7.0$ to 4.5. The chemical shift of C8 carbon remains unperturbed.

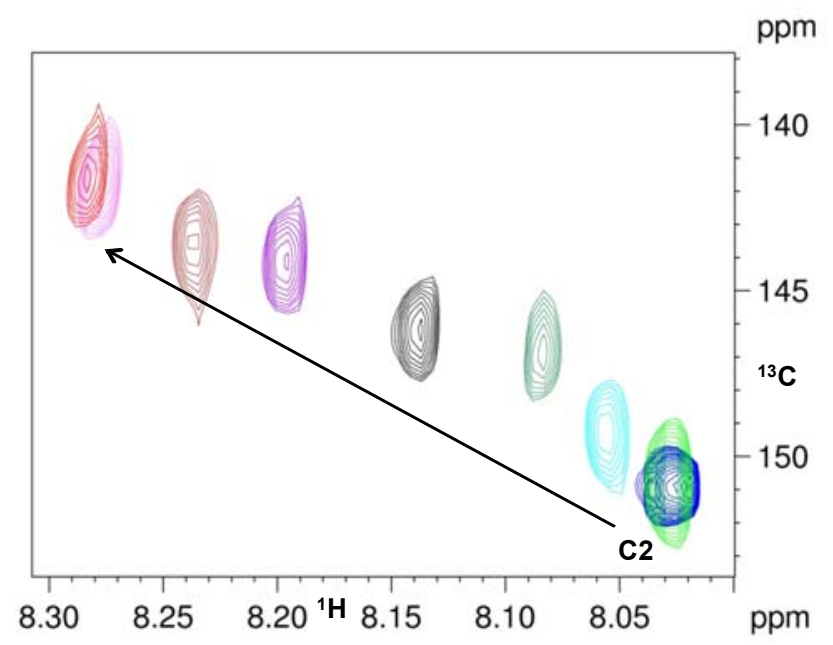

Figure S8: Overlay of ${ }^{1} \mathrm{H}^{13} \mathrm{C}$ HSQC of $2^{\prime}$-deoxy-7-deazaadenosine (29), depicting chemical shift perturbation of $\mathrm{C} 2$ carbon to up-field region in the NMR pH-metric titration from $\mathrm{pD} 7.4$ to 2.7. 


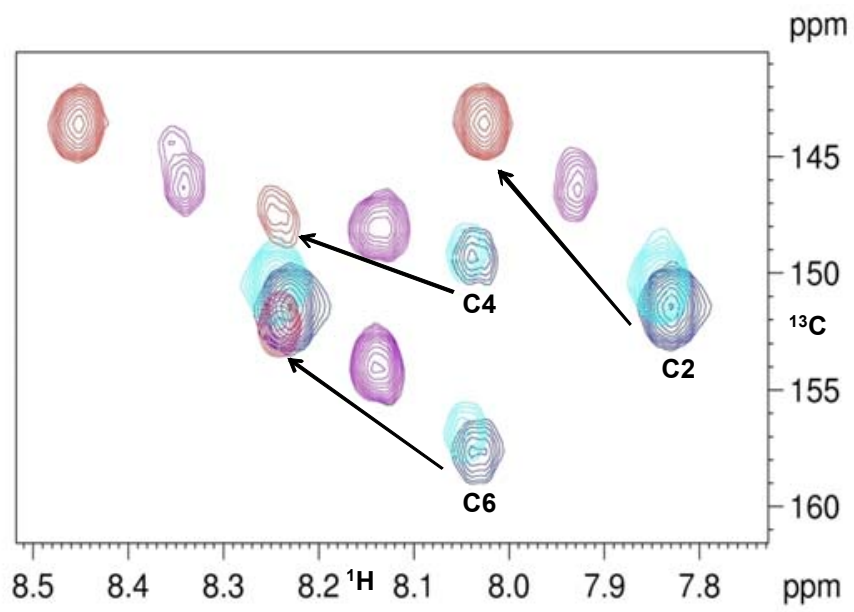

Figure S9: Overlay of ${ }^{1} \mathrm{H}-{ }^{13} \mathrm{C}$ HMBC spectra of $2^{\prime}$-deoxy-7-deazaadenosine (29), depicting the chemical shift perturbation (CSP) of $\mathrm{C} 4$ and $\mathrm{C} 6$ carbon towards up-field in the NMR pH-metric titration from $\mathrm{pD} 7.4$ to 4.4. CSP of $\mathrm{C} 2$ carbon towards up-field is also visible by the de-focussed ${ }^{1} J_{\mathrm{C} 2-\mathrm{H}}$ cross-peak.

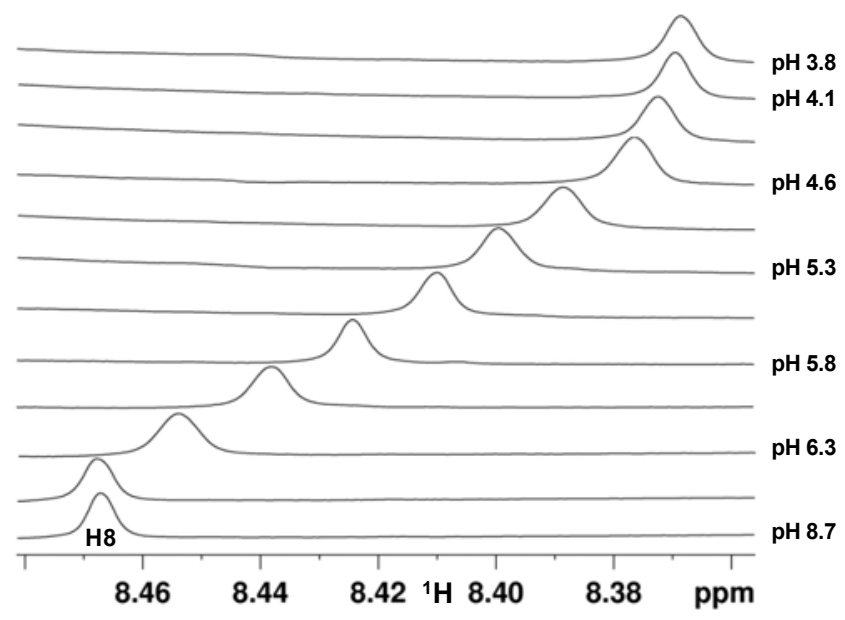

Figure S10: Chemical shift perturbation of the H8 proton of Asp-1-deaza-dAMP (21), depicting the up-field chemical shift (shielding effect, the 'wrong way chemical shift') during NMR pH-metric titration. 


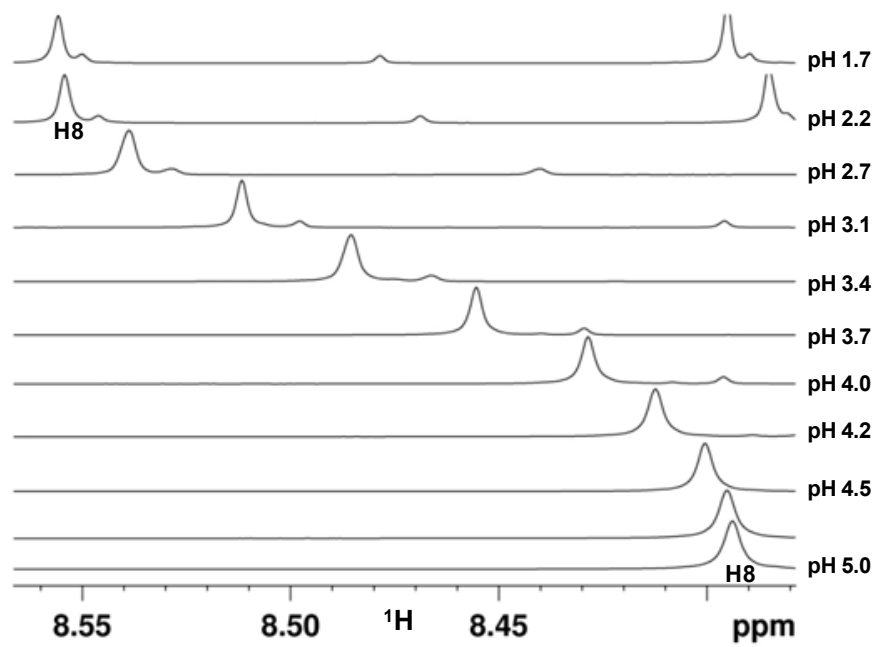

Figure S11: Chemical shift perturbation of the H8 proton of Asp-dAMP (1), depicting the down-field chemical shift (deshielding effect) during NMR pH-metric titration.

(A)

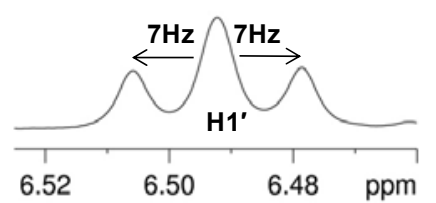

(B)
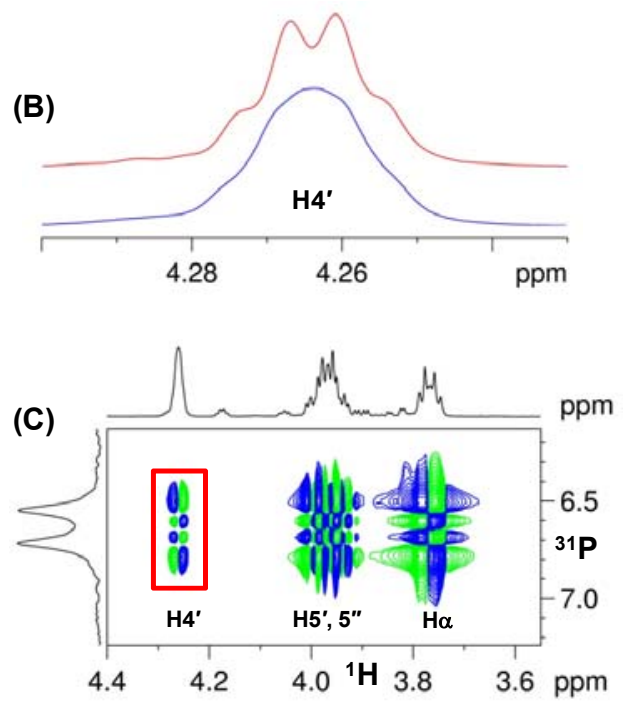

Figure S12: (A) H1' proton (triplet) peak of Asp-dAMP (1) indicating S-type sugar puckering; (B) ${ }^{31} \mathrm{P}$ coupled (blue) and decoupled (red) $\mathrm{H} 4$ ' proton peak of $\mathbf{1}$; (C) ${ }^{1} \mathrm{H}-{ }^{31} \mathrm{P}$ HETCOR spectrum of $\left({ }^{15} \mathrm{~N}\right)$ Asp-dAMP (1), recorded at $25^{\circ} \mathrm{C}$ (pD 5), cross-peak for ${ }^{4} J_{\mathrm{H} 4^{\prime}-\mathrm{P}}$ coupling shown within red box. 

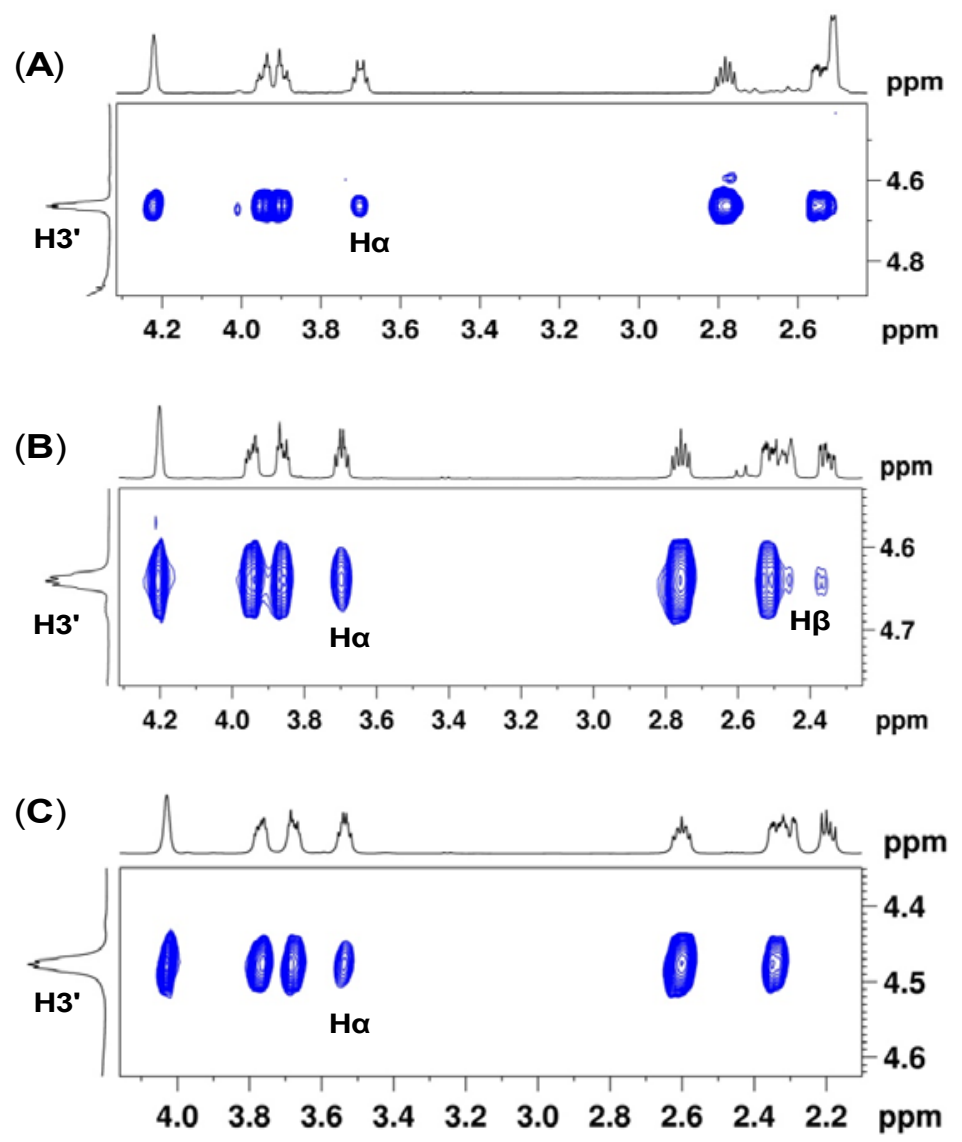

Figure S13: (A) Expansion of ROESY spectrum of Asp-dAMP (1 at pD 5.0, $10{ }^{\circ} \mathrm{C}$ ), showing NOE correlation between H3' sugar proton and Ha proton of aspartyl group; (B) Expansion of ROESY spectrum of 1 (at pD 8.0, 10 ${ }^{\circ} \mathrm{C}$ ), showing NOE correlation between $\mathrm{H}^{\prime}$ ' proton and $\mathrm{H} \alpha, \mathrm{H} \beta$ protons of aspartyl group; (C) Expansion of ROESY spectrum of Asp-1-deaza-dAMP $\left(21\right.$ at $\left.\mathrm{pD} 8.0,10{ }^{\circ} \mathrm{C}\right)$, showing NOE correlation between $\mathrm{H} 3{ }^{\prime}$ sugar proton and $\mathrm{H} \alpha$ proton. 
(A)

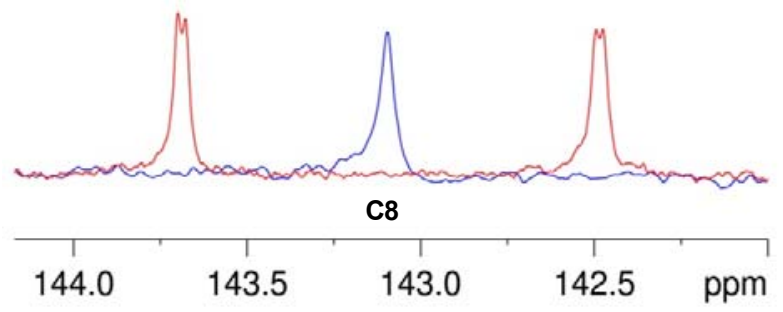

(B)
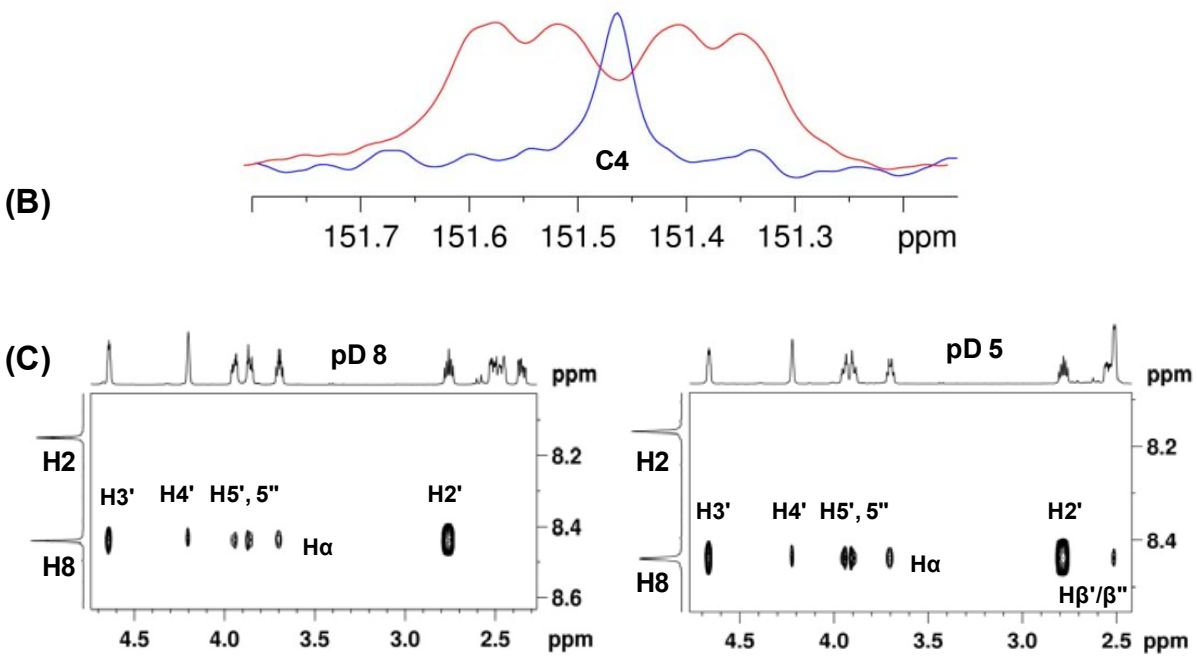

Figure S14: (A) ${ }^{1} \mathrm{H}$ coupled (red) and decoupled (blue) ${ }^{13} \mathrm{C}$ spectra of Asp-dAMP (1, recorded at $25{ }^{\circ} \mathrm{C}$ ), showing the splitting pattern of $\mathrm{C} 8$ carbon peak; (B) ${ }^{1} \mathrm{H}$ coupled (red) and decoupled (blue) $\mathrm{C} 4$ carbon peak of $\mathbf{1}$, showing the effect of $J_{\mathrm{CH}}$ couplings in the ${ }^{1} \mathrm{H}$ coupled ${ }^{13} \mathrm{C}$ spectrum; (C) Expansion of ROESY spectrum of 1 recorded at $10{ }^{\circ} \mathrm{C}$ (at pD 5 and 8), showing NOE correlation of $\mathrm{H} 8$ proton with sugar protons and aspartyl protons ( $\mathrm{H} \alpha$ and $\left.\mathrm{H} \beta^{\prime} / \beta^{\prime \prime}\right)$, whereas, $\mathrm{H} 2$ proton shows no NOE correlation. 

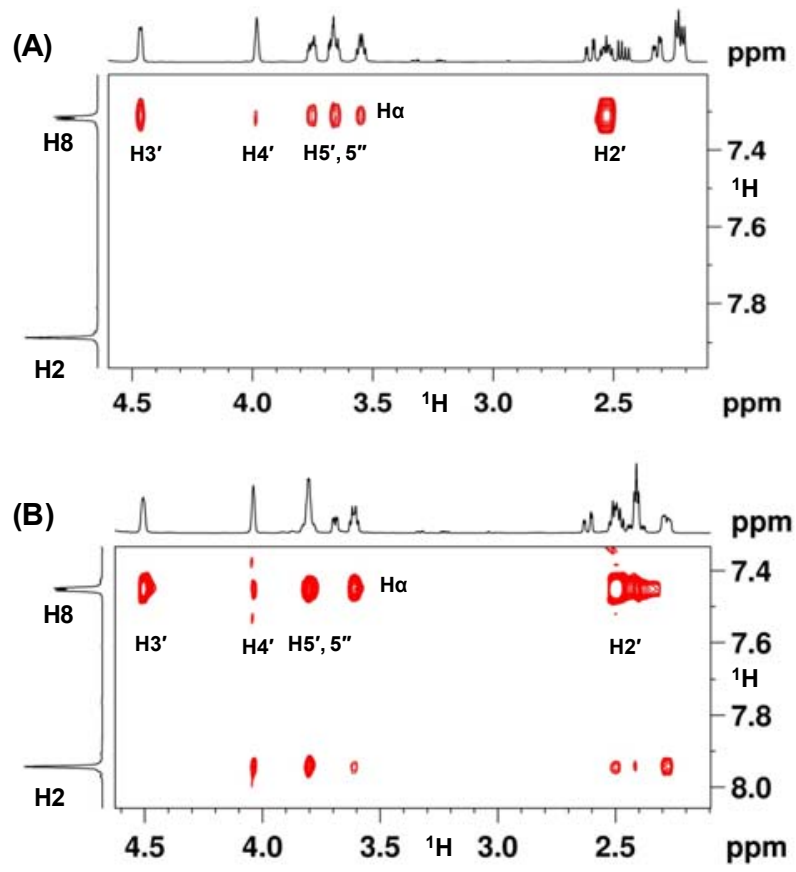

Figure S15: (A) Expansion of ROESY spectrum of Asp-7-deaza-dAMP (32, recorded at pD 8.0, $10{ }^{\circ} \mathrm{C}$ ), showing NOE correlation of $\mathrm{H} 8$ proton with sugar protons and aspartyl proton $(\mathrm{H} \alpha)$, whereas, $\mathrm{H} 2$ proton shows no NOE cross-peaks with any other protons, indicating predominant 'anti-like' conformation of the nucleobase moiety in the basic solution. (B) Expansion of ROESY spectrum of 32 (recorded at pD 5.0, $10{ }^{\circ} \mathrm{C}$ ), showing NOE correlations between $\mathrm{H} 2$ proton and the sugar protons and aspartyl proton $(\mathrm{H} \alpha)$ in addition to the NOE cross-peaks from $\mathrm{H} 8$ proton, indicating some population of 'syn' conformers in acidic solution. 
(A)
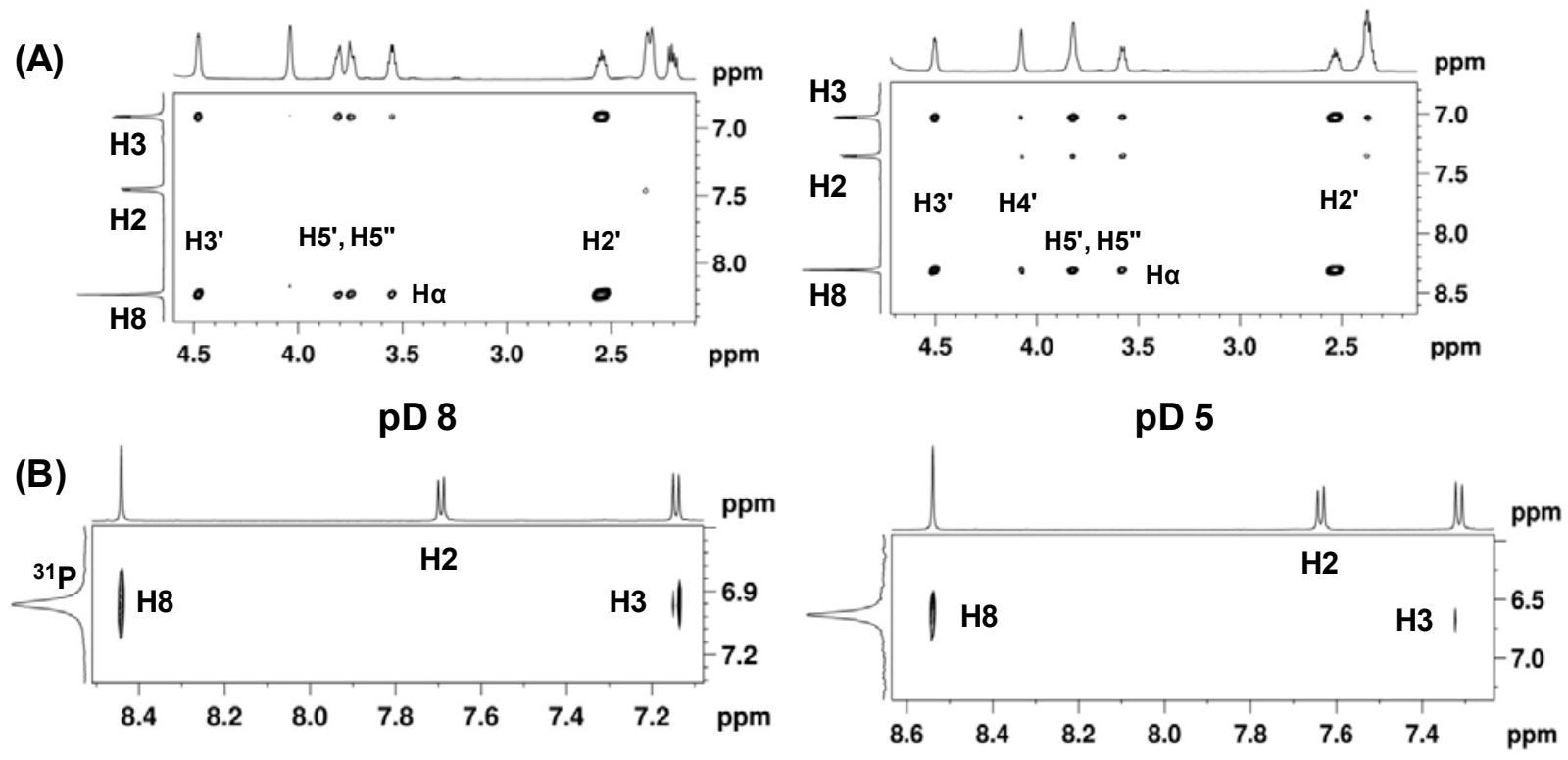

Figure S16: (A) Expansion of ROESY spectrum of Asp-3-deaza-dAMP (Left: at pD 8), showing NOE cross peaks between $\mathrm{H} 8, \mathrm{H} 3$ protons and sugar protons and $\mathrm{H} \alpha$ proton of aspartyl group, whereas, H2 proton shows no NOE cross-peaks with any protons, indicating predominant 'anti-like' conformation of the nucleobase moiety in basic solution, while at pD 5 (Right), H2 proton also shows NOE cross-peaks with sugar and aspartyl protons in addition to that of NOE cross-peaks from H8, H3 protons, indicating some population of 'syn' conformers in acidic condition. (B) Expansion of ${ }^{1} \mathrm{H}_{-}{ }^{31} \mathrm{P}$ HOESY spectrum of Asp-3-deaza-dAMP (33), recorded at pD 5 and 8, depicting NOE cross peak between $\mathrm{H} 8, \mathrm{H} 3$ protons and ${ }^{31} \mathrm{P}$, where, no cross-peak appeared between $\mathrm{H} 2$ proton and ${ }^{31} \mathrm{P}$, indicating close proximity of $\mathrm{H} 8$ and $\mathrm{H} 3$ proton to phosphorus under experimental conditions (pD 5 and 8). All spectra were recorded at $25^{\circ} \mathrm{C}$ in $\mathrm{D}_{2} \mathrm{O}$. 
(a)

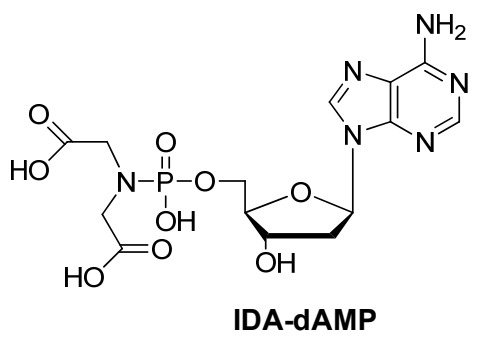

(b)

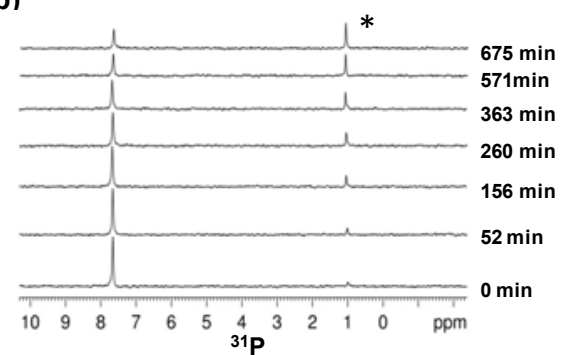

(c)

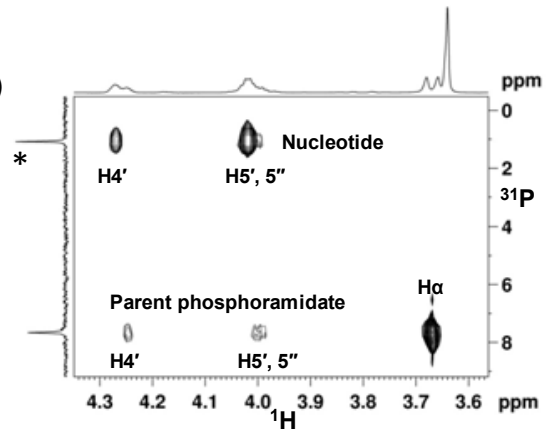

(d)

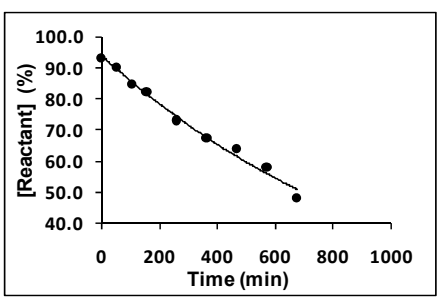

Figure S17: (a) Chemical structure of 2'-deoxyadenosine-5'-iminodiacetyl phosphoramidate (IDA-dAMP). (b) Progress of the hydrolytic reaction of IDA-dAMP at pD $6.0\left(T=70{ }^{\circ} \mathrm{C}\right)$, depicted by stack plot of ${ }^{31} \mathrm{P}$ spectra at different time intervals, showing the disappearance of the parent ${ }^{31} \mathrm{P}$ peak $(\sim 7.5 \mathrm{ppm})$ and gradual increase of only one ${ }^{31} \mathrm{P}$ peak $(\sim 1 \mathrm{ppm})$ indicated in asterisk $(*)$. (c) ${ }^{1} \mathrm{H}^{-}{ }^{31} \mathrm{P}$ TOCSY spectrum of IDA-dAMP after the hydrolysis reaction at $\mathrm{pD} 6.0\left(70{ }^{\circ} \mathrm{C}\right)$, depicting the formation of corresponding nucleotide by only P-N bond cleavage. Nucleotide (phosphorus peak in asterisk) showed correlation with $\mathrm{H}^{\prime}, \mathrm{H} 5^{\prime}$ and $\mathrm{H} 5{ }^{\prime \prime}$ of sugar moiety, whereas, the parent phosphoramidate showing correlation with $\mathrm{H} \alpha$ of iminodiacetyl moiety along with $\mathrm{H} 4{ }^{\prime}$ and $\mathrm{H} 5^{\prime}, 5^{\prime \prime}$ of sugar moiety. (d) Concentation decay (\%) of the parent phosphoramidate with respect to time is plotted. 
Table S1: Rate constants $\left(k \times 10^{-4} \mathrm{~min}^{-1}\right)$ for the hydrolytic reactions of Asp-1-deaza-dAMP (21) at $40{ }^{\circ} \mathrm{C}(\mathrm{pD} 5.0$ 7.0).

\begin{tabular}{lccc}
\hline & \multicolumn{3}{c}{$k \times 10^{-4}$} \\
\cline { 2 - 4 } Compound entry & pD 5.0 & pD 6.0 & pD 7.0 \\
\hline Asp-1-deaza-dAMP (21) & 110.26 & 52.15 & 11.65 \\
\hline
\end{tabular}

Table S2: Homo-nuclear $\left({ }^{1} \mathrm{H}-{ }^{1} \mathrm{H}\right)$ and hetero-nuclear $\left({ }^{31} \mathrm{P}-{ }^{1} \mathrm{H},{ }^{31} \mathrm{P}-{ }^{13} \mathrm{C},{ }^{1} \mathrm{H}-{ }^{13} \mathrm{C},{ }^{15} \mathrm{~N}-{ }^{1} \mathrm{H}\right)$ coupling constants of AspdAMP (1) and ${ }^{15} \mathrm{~N}(\mathrm{NH})$-Asp-dAMP in $\mathrm{D}_{2} \mathrm{O}\left(25^{\circ} \mathrm{C}, \mathrm{pD} 5.0,8.0\right)$. ${ }^{*}$ No hetero-nuclear ${ }^{3} \mathrm{~J}^{4} J_{15 \mathrm{~N}-13 \mathrm{C}}$ couplings were observed.

\begin{tabular}{|c|c|c|}
\hline Couplings & $\begin{array}{c}\mathrm{pD} 5.0 \\
(\mathrm{~Hz})\end{array}$ & $\begin{array}{l}\text { pD } 8.0 \\
(\mathrm{~Hz})\end{array}$ \\
\hline${ }^{3} J_{\mathrm{H} 1^{\prime}-\mathrm{H} 2^{\prime} / \mathrm{H} 2^{\prime \prime}}$ & 7 & 7 \\
\hline${ }^{3} J_{\mathrm{H} 1^{\prime}-\mathrm{C} 8}$ & 4.5 & 4.5 \\
\hline${ }^{3} J_{\mathrm{H} 1^{\prime}-\mathrm{C} 4}$ & -1.8 & -1.8 \\
\hline${ }^{3} J_{\mathrm{H}^{\prime}-\mathrm{H} 5^{\prime} / \mathrm{H} 5^{\prime \prime}}$ & 3.5 & 3.8 \\
\hline${ }^{3} J_{\mathrm{H} 5^{\prime} / \mathrm{H} 5^{\prime \prime}-\mathrm{P}}$ & $4.5-5.0$ & $4.5-5.0$ \\
\hline${ }^{3} J_{\mathrm{C} 4^{\prime}-\mathrm{P}}$ & 9.3 & 9.3 \\
\hline${ }^{4} J_{\mathrm{H}^{4^{\prime}}-\mathrm{P}}$ & $-1-2$ & $-1-2$ \\
\hline${ }^{3} J_{\mathrm{H} \alpha-\mathrm{H} \beta^{\prime} / \mathrm{H} \beta^{\prime \prime}}$ & 6.0 & $7.7 / 5.3$ \\
\hline${ }^{3} J_{\mathrm{H} \alpha-\mathrm{P}}$ & 8.9 & 8.3 \\
\hline${ }^{4} J_{\mathrm{H} \beta^{\prime} / \mathrm{H} \beta^{\prime \prime}-\mathrm{P}}$ & $\sim 0$ & 1.7 \\
\hline${ }^{3} J_{\mathrm{P}-\mathrm{C} \beta}$ & $4.5-5.0$ & 6.7 \\
\hline${ }^{3} J_{15 \mathrm{~N}-\mathrm{H} \beta^{\prime} / \beta^{\prime \prime}} *$ & $4-1.5$ & $2.5 / 3.4$ \\
\hline
\end{tabular}




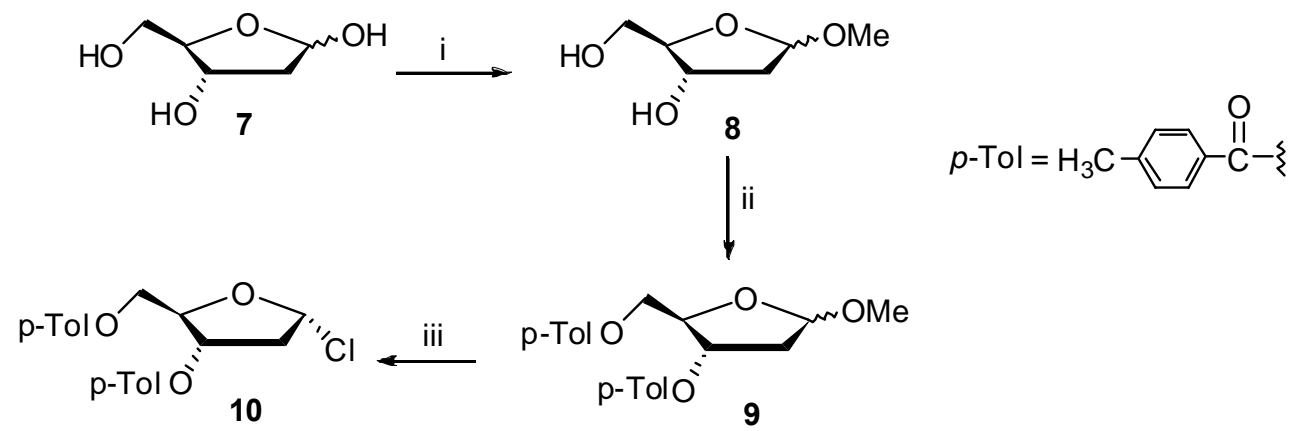

Scheme S1: (i) $1.25 \mathrm{M} \mathrm{HCl}$ in methanol, $\mathrm{MgCO}_{3}, \mathrm{rt}, 10 \mathrm{~min}, 88 \%$; (ii) $p$-toluoyl chloride (2 eq), $\mathrm{Et}_{3} \mathrm{~N}$ (2.2 eq), dry acetone, rt, overnight, $67 \%$; (iii) dry $\mathrm{HCl}, \mathrm{Et}_{2} \mathrm{O}, 0{ }^{\circ} \mathrm{C}, 75 \%$.

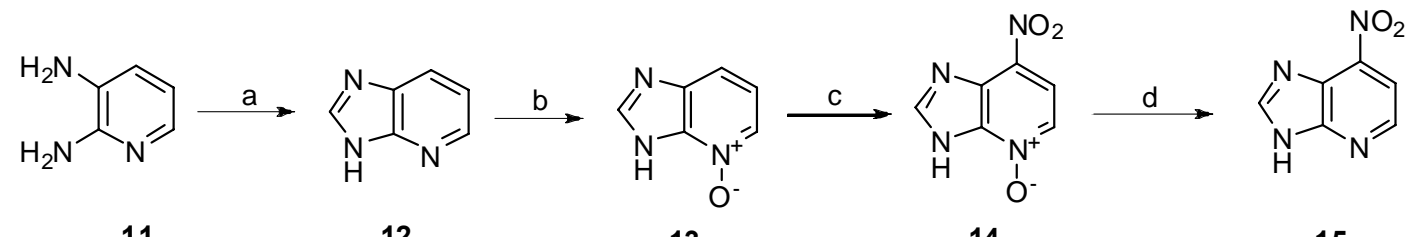

13

14

15

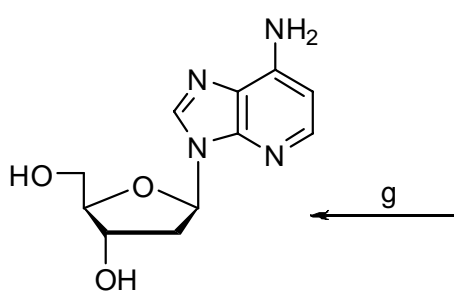

18

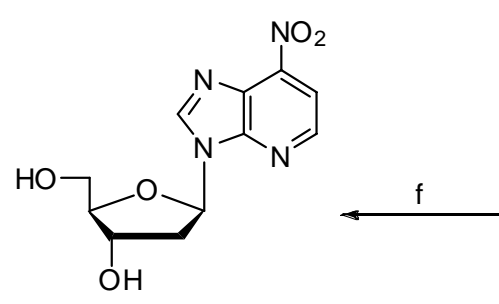

17

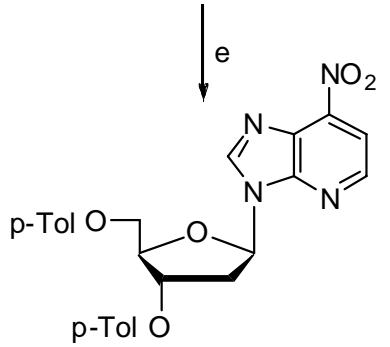

16<smiles>Nc1ccnc2c1ncn2[C@@H]1C[C@H](O)[C@@H](COP(=O)(O)O)O1</smiles>

19
$\mathrm{MeOOC}$

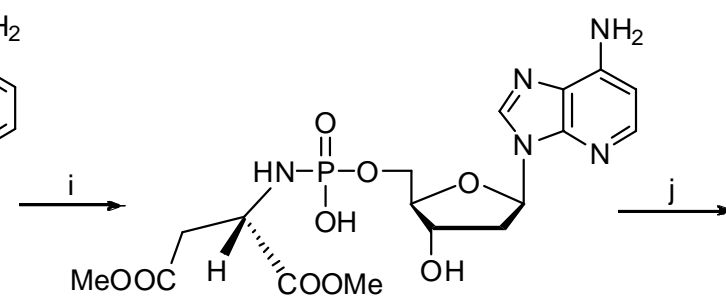

20

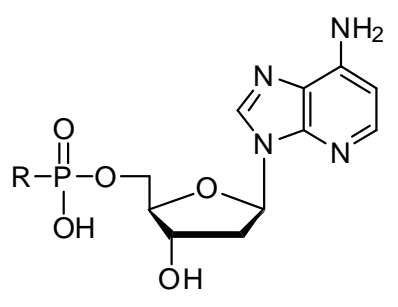

21

$21 \mathrm{R}=\mathrm{L}-\mathrm{Asp}$

$22 \mathrm{R}=\mathrm{Gly}$

$23 \mathrm{R}=\beta$-Ala

Scheme S2: (a) Triethylorthoformate (13 eq), formic acid (57 eq), reflux, 99\%; (b) meta-chloroperbenzoic acid (1.5 eq), acetic acid, rt, over night, 60\%; (c) $90 \%$ fuming nitric acid (18 eq), trifluoroacetic acid, $90{ }^{\circ} \mathrm{C}, 4 \mathrm{~h}, 63 \%$; (d) phosphorus trichloride ( $8 \mathrm{eq}$ ), dry $\mathrm{ACN}, 0{ }^{\circ} \mathrm{C}, 1.5 \mathrm{~h}, 87 \%$; (e) 2-deoxy-3,5-di-O-p-toluoyl- $\alpha$-D-ribofuranosyl 
chloride (10) (1.1 eq), $\mathrm{NaH}$ (1.1 eq), dry $\mathrm{ACN}, 0{ }^{\circ} \mathrm{C}, 6 \mathrm{~h}, 73 \%$; (f) saturated ammonia in methanol, rt, overnight, 91\%; (g) ammonium formate (50 eq), Pd/C, methanol, $75{ }^{\circ} \mathrm{C}, 3 \mathrm{~h}, 83 \%$; (h) phosphorus oxychloride (1 eq), dry triethylphosphate, TEAB, $0{ }^{\circ} \mathrm{C}, 1 \mathrm{~h}, 95 \%$; (i) L-aspartic acid dimethyl ester hydrochloride (7 eq), Et $3 \mathrm{~N}$ (14 eq), DCC (10 eq), tert-BuOH: $\mathrm{H}_{2} \mathrm{O}(5: 1), 95{ }^{\circ} \mathrm{C}, 2-3 \mathrm{~h}, 95 \%$; (j) $0.4 \mathrm{M} \mathrm{NaOH}$ in $\mathrm{MeOH}: \mathrm{H}_{2} \mathrm{O}$ (4:1), TEAA, rt, 2-3h, $91 \%$.<smiles>CCCc1ncnc2[nH]ccc12</smiles><smiles>CC(C)C</smiles>

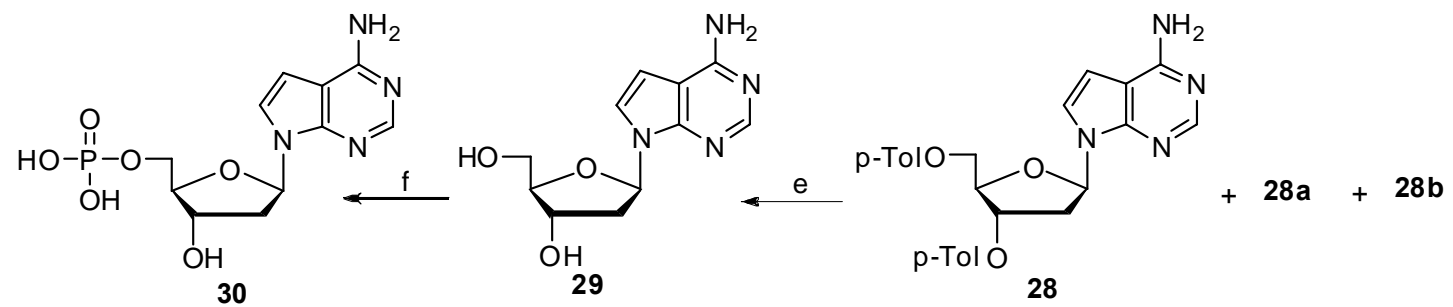

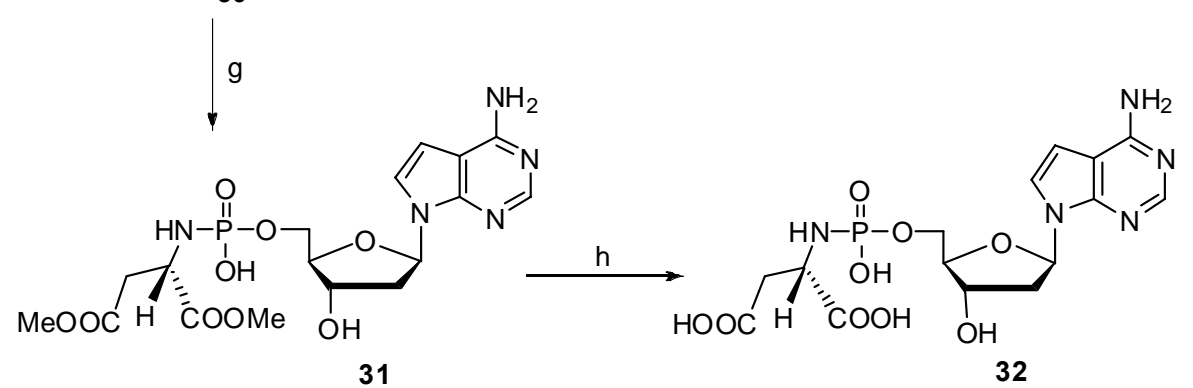

Scheme S3: (a) $\mathrm{I}_{2}$ (1.1 eq), $\mathrm{K}_{2} \mathrm{CO}_{3}\left(1.5\right.$ eq), $\mathrm{H}_{2} \mathrm{O} / \mathrm{DMF}, 40{ }^{\circ} \mathrm{C}, 20 \mathrm{~h}, 81 \%$; (b) trimethylsilylacetylene (2 eq), bis(triphenylphosphine)-palladium(II)chloride, $\mathrm{Et}_{3} \mathrm{~N}$ (1.2 eq), CuI, DMF, $60{ }^{\circ} \mathrm{C}, 2 \mathrm{~h}, 70 \%$; (c) potassium tert-butoxide (1.3 eq), NMP, $90{ }^{\circ} \mathrm{C}, 5$ h, 81\%; (d) 2-deoxy-3,5-di-O- $p$-toluoyl- $\alpha$-D-ribofuranosyl chloride (10), TDA-1, KOH, dry $\mathrm{ACN}, \mathrm{rt}, 57 \%$; (e) saturated ammonia in methanol, rt, $48 \mathrm{~h}, 95 \%$; (f) phosphorus oxychloride (1 eq), dry triethylphosphate, TEAB, $0{ }^{\circ} \mathrm{C}, 1 \mathrm{~h}, 81 \%$; (g) L-aspartic acid dimethyl ester hydrochloride (7 eq), $\mathrm{Et}_{3} \mathrm{~N}$ (14 eq), DCC (10 eq), tert-BuOH: $\mathrm{H}_{2} \mathrm{O}(5: 1), 95^{\circ} \mathrm{C}, 2-3 \mathrm{~h}, 70 \%$; (h) $0.4 \mathrm{M} \mathrm{NaOH}$ in $\mathrm{MeOH}: \mathrm{H}_{2} \mathrm{O}(4: 1)$, TEAA, rt, $2-3 \mathrm{~h}, 80 \%$. 
Note: Intermediates (12-18 and 27-29) are assigned according to the systematic numbering (Figure S1) and for the rest of the compounds; purine numbering system (Figure S1) is followed for the atom assignments.

\section{Synthesis:}

General: NMR spectra were recorded on Bruker Avance II $300 \mathrm{MHz}$ with $5 \mathrm{~mm}$ broad band probe, $500 \mathrm{MHz}$ spectrometer equipped with a TXI-HCP Z gradient probe or on Bruker Avance II $600 \mathrm{MHz}$ spectrometer with a $5 \mathrm{~mm}$ TCI-HCN Z gradient cryo-probe (Biomacs). The spectra were processed with Bruker Topspin 2.1 software. Chemical shifts $(\delta)$ were expressed in parts per million (ppm). ${ }^{1} \mathrm{H}$ and ${ }^{13} \mathrm{C}$ NMR chemical shifts were referenced relative to TMS peak $(\delta=$ $0.00 \mathrm{ppm}$ ). ${ }^{31} \mathrm{P}$ NMR chemical shifts were referenced to an external $85 \% \mathrm{H}_{3} \mathrm{PO}_{4}$ standard $(\delta=$ $0.00 \mathrm{ppm}$ ). All signals in Proton and carbon 1D NMR spectra were assigned by $2 \mathrm{D}$ COSY, ${ }^{1} \mathrm{H}-$ ${ }^{13} \mathrm{C}$ (natural abundance) HSQC and ${ }^{1} \mathrm{H}-{ }^{13} \mathrm{C}$ HMBC NMR spectra. Standard mass spectra were recorded on an ion trap mass spectrometer (LCQ DuO, Thermo Finnigan, San Jose, CA) using electron spray ionization (ESI); data were acquired with the $\mathrm{LAC} / \mathrm{E}^{32}$ system (Waters). High resolution mass spectra (HRMS) were obtained with a Q-Tof 2TM (Micromass Ltd.) coupled to a CapLC system (Waters). Chemicals of analytical and synthetic grade were obtained from commercial sources and were used as such. 2,3-diaminopyridine, tris(3,6-dioxaheptyl)amine (TDA-1): Alfa Aesar; triehtylorthoformate, meta-chloroperbenzoic acid, trifluoroacetic acid, dry acetone, tert-butanol, 2-deoxy- $\alpha / \beta$-D-ribose, $p$-toluoyl chloride, ammonium formate, (trimethylsilyl) acetylene, 4,6-diaminopyrimidine hemisulfate monohydrate: Acros Organics; fuming nitric acid (90\%), 1.25 M HCl in methanol, DCC: Fluka; phosphorus trichloride: Merck; $\mathrm{Pd} / \mathrm{C}$, phosphorus oxychloride, triethyl phosphate, L-aspartic acid dimethyl ester hydrochloride: Aldrich. Technical solvents were obtained from Brenntag (Deerlijk, Belgium). Flash silica column chromatography was performed on Davisil silica gel 60, 0.040-0.063 mm (Grace Davison).Thin-layer chromatography (TLC) was performed on Alugram silica gel UV254 mesh 60, $0.20 \mathrm{~mm}$ (Macherey-Nagel). Celite 545 was purchased from VWR International. 
General synthetic procedure for DCC assisted coupling: The example described is for 2'deoxy-1-deazaadenosine-5'-dimethoxyaspartyl phosphoramidate (20): In a two neck flask 2'deoxy-1-deazaadenosine-5'- monophosphate (19) $(0.06 \mathrm{~g}, 0.18 \mathrm{mmol})$ and L-aspartic acid dimethyl ester hydrochloride $(0.25 \mathrm{~g}, 1.27 \mathrm{mmol})$ were dissolved in a mixture of tert-butanol and water $(5: 1,6.0 \mathrm{~mL})$. Triethylamine $(0.35 \mathrm{~mL})$ was added. $0.37 \mathrm{~mL}$ of freshly prepared solution of $\mathrm{N}, \mathrm{N}^{\prime}$-dicyclohexylcarbodiimide (DCC) in tert-butanol $(0.5 \mathrm{~g} / \mathrm{mL})$ was added dropwise to have 5 equivalents of DCC in the reaction mixture. The reaction mixture was heated for $2-3 \mathrm{~h}$ at $95{ }^{\circ} \mathrm{C}$ while stirring under argon. The progress of the reaction was monitored by TLC (iPrOH: $\mathrm{H}_{2} \mathrm{O}: \mathrm{NH}_{3}, 6: 2: 2$ ) every hour. After $1 \mathrm{~h}$, another 5 equivalents of DCC was added to the reaction mixture. Upon completion the reaction mixture was cooled down to room temperature and the solvent was removed by rotary evaporation keeping the temperature of water bath below $30^{\circ} \mathrm{C}$. The dry residue was suspended in water and washed 3 times with diethyl ether until the water was clear. The aqueous layer was lyophilized and the residue was purified by silica column chromatography by eluting with gradient of $\mathrm{MeOH}$ in $\mathrm{CHCl}_{3}(20 \%$ to $40 \%)$ to obtain 2'-deoxy-1deazaadenosine-5'-dimethoxyaspartyl phosphoramidate (20) as white solid (95\%). TLC $\left(\mathrm{iPrOH} / \mathrm{H}_{2} \mathrm{O} / \mathrm{NH}_{3}, 6: 2: 2\right): \mathrm{R}_{f}=0.73 .{ }^{1} \mathrm{H}$ NMR $(500 \mathrm{MHz}, \mathrm{MeOD}) \delta: 8.41(\mathrm{~s}, 1 \mathrm{H}, \mathrm{H}-8), 7.99(\mathrm{~d}$, $\left.1 \mathrm{H}, J_{2,1}=5.9 \mathrm{~Hz}, \mathrm{H}-2\right), 6.85\left(\mathrm{~d}, 1 \mathrm{H}, J_{1,2}=5.9 \mathrm{~Hz}, \mathrm{H}-1\right), 6.48$ (apparent t, $1 \mathrm{H}, J_{1^{\prime}, 2^{\prime} \mathrm{a}}=J_{1^{\prime}, 2^{\prime} \mathrm{b}}=6.4$ Hz, H-1'), 4.65-4.58 (m, 1H, H-3'), 4.14-3.96 (m, 4H, H-4', H-5', H5" \& H- $\alpha$ ), 3.67 (s, 3H, $\mathrm{CH}_{3}$ ), 3.57 (s, 3H, $\left.\mathrm{CH}_{3}\right) 2.77$ (d, $\left.2 \mathrm{H}, J_{\mathrm{H}-\alpha, \mathrm{H}-\beta}=4.75, \mathrm{H}-\beta\right), 2.70-2.65$ (m, 1H, H-2'a), 2.46-2.42 (m, 1H, H-2'b). ${ }^{13} \mathrm{C}$ NMR (125 MHz, MeOD) $\delta: 175.1 \& 173.1$ ( $\alpha \& \beta \mathrm{CO}$ ), 151.5 (C-6), 143.5 (C-4), 142.0 (C-2), 140.7 (C-8), 124.5 (C-5), 104.2 (C-1), 88.2 (C-4'), 86.7 (C-1'), 73.0 (C-3'), $65.7\left(\mathrm{C}-5^{\prime}\right), 52.9(\mathrm{C}-\alpha), 52.8\left(\mathrm{COOCH}_{3}\right), 52.2\left(\mathrm{COO}^{-} \mathrm{H}_{3}\right), 41.6\left(\mathrm{C}-2^{\prime}\right), 39.9(\mathrm{C}-\beta) .{ }^{31} \mathrm{P}$ NMR (121MHz, MeOD) $\delta$ : 5.28. ES-MS calculated for $\mathrm{C}_{17} \mathrm{H}_{24} \mathrm{~N}_{5} \mathrm{O}_{9} \mathrm{P}, 473.13$; found (negative mode) $471.7[\mathrm{M}-\mathrm{H}]^{-}$.

General protocol for methyl ester deprotection: The example described is for the synthesis of 2'-Deoxy-1-deazaadenosine-5'-aspartyl phosphoramidate (21): A solution $(5.9 \mathrm{~mL})$ of $0.4 \mathrm{M}$ $\mathrm{NaOH}$ (in $\mathrm{MeOH} / \mathrm{H}_{2} \mathrm{O}, 4: 1$ ) to 2'-deoxy-1-deazaadenosine-5'-dimethoxyaspartyl phosphoramidate (20) (0.08 g, $0.17 \mathrm{mmol})$ was added. The reaction mixture was stirred at room temperature under argon for 2-3 $\mathrm{h}$. The course of the reaction was monitored by TLC (iPrOH/ $\left./ \mathrm{H}_{2} \mathrm{O} / \mathrm{NH}_{3}, 6: 2: 2\right)$ until the disappearance of the starting material. The reaction mixture was neutralized by addition of TEAA $(1 \mathrm{M}, \mathrm{pH} \sim 7.5)$. The solvent was removed under reduced 
pressure and the resulting residue was dried by lyophilization. The desired product was purified by silica column chromatography eluting with the following gradient [iPrOH, $\mathrm{iPrOH}: \mathrm{H}_{2} \mathrm{O}: \mathrm{NH}_{3}$ (20:1:1), iPrOH: $\mathrm{H}_{2} \mathrm{O}: \mathrm{NH}_{3} \quad(10: 1: 1), \quad \mathrm{PrOH}: \mathrm{H}_{2} \mathrm{O}: \mathrm{NH}_{3} \quad$ (7:1:1)] to obtain 2'-deoxy-1deazaadenosine-5'-aspartyl phosphoramidate (21, 91\%). TLC (iPrOH/ $\left.\mathrm{H}_{2} \mathrm{O} / \mathrm{NH}_{3}, 6: 2: 2\right): \mathrm{R}_{f}=0.4$. ${ }^{1} \mathrm{H}$ NMR (600 MHz, $\left.\mathrm{D}_{2} \mathrm{O}\right)$ ) 8.35 (s, 1H, H-8), 7.83 (d, 1H, $\left.J_{2,1}=5.9 \mathrm{~Hz}, \mathrm{H}-2\right), 6.52$ (d, 1H, $J_{1,2}$ $=5.9 \mathrm{~Hz}, \mathrm{H}-1), 6.41\left(\mathrm{dd}, 1 \mathrm{H}, J_{1^{\prime}, 2^{\prime} \mathrm{a}}=7.75 \mathrm{~Hz}, J_{1^{\prime}} 2^{\prime} \mathrm{b}=6.30 \mathrm{~Hz}, \mathrm{H}-1^{\prime}\right), 4.61-4.58\left(\mathrm{~m}, 1 \mathrm{H}, \mathrm{H}-3^{\prime}\right)$, 4.18-4.14 (m, 1H, H-4'), 3.92-3.80 (m, 2H, H-5'), 3.67-3.64 (m, 1H, H- $\alpha$ ), 2.73-2.29 (m, 4H, $\mathrm{H}-2^{\prime}, \mathrm{H} 2 "$ \& $\left.\mathrm{H}-\beta\right) .{ }^{13} \mathrm{C}$ NMR (150 MHz, $\left.\mathrm{D}_{2} \mathrm{O}\right) \delta: 181.2 \& 181.1$ ( $\alpha$ \& $\left.\beta \mathrm{CO}\right), 147.4$ (C-6), 144.5 (C-4), 143.6 (C-2), 139.1 (C-8), 122.4 (C-5), 103.8 (C-1), 85.8 (C-4'), 83.4 (C-1'), 71.2 (C-3'), $63.8\left(\mathrm{C}-5^{\prime}\right), 54.7(\mathrm{C}-\alpha), 42.9$ ( C- $\beta$ ), $38.6\left(\mathrm{C}-2^{\prime}\right) .{ }^{31} \mathrm{P}$ NMR (121 MHz, $\left.\mathrm{D}_{2} \mathrm{O}\right)$ ) $:$ 6.50. HRMS (ESI) calculated for $\mathrm{C}_{15} \mathrm{H}_{20} \mathrm{~N}_{5} \mathrm{O}_{9} \mathrm{P}, 445.0998$; found (negative mode) $444.0904[\mathrm{M}-\mathrm{H}]^{-}$.

General synthesis for direct 5'-phosphorylation of deaza-nucleoside: Compounds 19 and $\mathbf{3 0}$ were synthesised by selectively phosphorylating at $5^{\prime}-\mathrm{OH}$ in the unprotected nucleoside. As an example, synthetic procedure for synthesis of 2'-deoxy-1-deazaadenosine-5'-monophosphate (19) is described here: To a solution of 7-amino-3-(2'-deoxy- $\beta$-D-ribofuranosyl)-imidazo[4,5b]pyridine $(18)(0.1 \mathrm{~g}, 0.4 \mathrm{mmol})$ in dry triethylphosphate $(5.5 \mathrm{~mL})$ at $0^{\circ} \mathrm{C}$, phosphorus oxychloride $(37.0 \mu \mathrm{l}, 0.4 \mathrm{mmol})$ was added. The mixture was stirred at $0^{\circ} \mathrm{C}$ for $1 \mathrm{~h}$. Excess of phosphorus oxychloride was hydrolysed by slow addition of aqueous triethylammonium bicarbonate buffer solution (TEAB, $1 \mathrm{M}, \mathrm{pH} \sim 7.5$ ). The crude product was purified on silica column eluting with the following gradient to obtain 2'-deoxy-1-deazaadenosine-5'monophosphate (19) as white solid (75\%): a) iPrOH, b) iPrOH: $\mathrm{H}_{2} \mathrm{O}: \mathrm{NH}_{3}$ (20:1:1), c) iPrOH: $\mathrm{H}_{2} \mathrm{O}: \mathrm{NH}_{3}$ (10:1:1), d) iPrOH: $\mathrm{H}_{2} \mathrm{O}: \mathrm{NH}_{3}$ (7:1:1). TLC (iPrOH/ $\left.\mathrm{H}_{2} \mathrm{O} / \mathrm{NH}_{3}, 6: 2: 2\right): \mathrm{R}_{f}=0.45$. ${ }^{1} \mathrm{H}$ NMR (500 MHz, $\left.\mathrm{D}_{2} \mathrm{O}\right) \delta: 8.36$ (s, 1H, H-8), 7.91 (d, 1H, $\left.J_{2,1}=6.0 \mathrm{~Hz}, \mathrm{H}-2\right), 6.57$ (d, 1H, $J_{1,2}$ $=6.0 \mathrm{~Hz}, \mathrm{H}-1), 6.46$ (apparent t, $\left.1 \mathrm{H}, J_{1^{\prime}, 2^{\prime} \mathrm{a}}=J_{1^{\prime}, 2^{\prime} \mathrm{b}}=6.5 \mathrm{~Hz}, \mathrm{H}-1^{\prime}\right), 4.71-4.68\left(\mathrm{~m}, 1 \mathrm{H}, \mathrm{H}-3^{\prime}\right), 4.28-$ 4.23 (m, 1H, H-4'), 4.05-3.97 (m, 2H, H-5', H5"), 2.77-2.71 (m, 1H, H-2'a), 2.57-2.52 (m, 1H, H-2'b). ${ }^{13} \mathrm{C}$ NMR (125MHz, D 2 ) $\delta: 147.6$ (C-6), 143.5 (C-4), 142.8 (C-2), 139.1 (C-8), 122.3 (C-5), 103.5 (C-1), 85.7 (C-4'), 83.7 (C-1'), 71.1 (C-3'), 64.1 (C-5'), 38.8 (C-2'). ${ }^{31} \mathrm{P}$ NMR $\left(121 \mathrm{MHz}, \mathrm{D}_{2} \mathrm{O}\right) \delta: 1.83$. HRMS (ESI) calculated for $\mathrm{C}_{11} \mathrm{H}_{15} \mathrm{~N}_{4} \mathrm{O}_{6} \mathrm{P}, 330.0729$; found (negative mode) $329.0594[\mathrm{M}-\mathrm{H}]^{-}$. 


\section{Characterisation data for compounds 1-6 and their intermediates (1a-6a)}

2'-Deoxyadenosine-5'-dimethoxyaspartyl phosphoramidate (1a): TLC ( $\mathrm{iPrOH} / \mathrm{H}_{2} \mathrm{O} / \mathrm{NH}_{3}$, 7:1:2): $\mathrm{R}_{f}=0.59 .{ }^{1} \mathrm{H}$ NMR (300 MHz, MeOD) $\delta: 8.53$ (s, 1H, H-8), 8.23 (s, 1H, H-2), 6.51 (apparent t, 1H, $\left.J_{1^{\prime}, 2^{\prime} \mathrm{a}}=J_{1^{\prime}, 2^{\prime} \mathrm{b}}=6 \mathrm{~Hz}, \mathrm{H}-1^{\prime}\right), 4.69-4.61\left(\mathrm{~m}, 1 \mathrm{H}, \mathrm{H}-3^{\prime}\right), 4.15-4.02\left(\mathrm{~m}, 4 \mathrm{H}, \mathrm{H}-4^{\prime}, \mathrm{H}-\right.$ 5', H-5" \& H- $\alpha$ ), 3.69 (s, 3H, $\mathrm{CH}_{3}$ ), 3.60 (s, 3H, CH $\mathrm{CH}_{3}$ ), 2.89-2.71 (m, 2H, H-2'a \& H- $\beta$ ), 2.532.34 (m, 1H, H-2'b). ${ }^{13} \mathrm{C}$ NMR (75 MHz, MeOD) $\delta: 175.9 \& 173.9(\alpha \& \beta \mathrm{CO}), 158.2$ (C-6), 154.7 (C-2), 151.4 (C-4), 141.9 (C-8), 121.1 (C-5), 88.9 (C-4'), 86.2 (C-1'), 74.0 (C-3'), 66.6 (C$\left.5^{\prime}\right), 53.7(\mathrm{C}-\alpha), 53.6\left(\mathrm{COOCH}_{3}\right), 53.0\left(\mathrm{COOCH}_{3}\right), 42.3\left(\mathrm{C}-2^{\prime}\right), 40.8(\mathrm{C}-\beta) \cdot{ }^{31} \mathrm{P}$ NMR $(121 \mathrm{MHz}$, MeOD) $\delta$ : 5.66. ES-MS calculated for $\mathrm{C}_{16} \mathrm{H}_{23} \mathrm{~N}_{6} \mathrm{O}_{9} \mathrm{P}, 474.36$; found (negative mode) 473.3 [M$\mathrm{H}]^{-}$.

2'-Deoxyadenosine-5'-aspartyl phosphoramidate (1): TLC (iPrOH/ $\left.\mathrm{H}_{2} \mathrm{O} / \mathrm{NH}_{3}, 7: 1: 2\right): \mathrm{R}_{f}=$ 0.22. ${ }^{1} \mathrm{H}$ NMR (500 MHz, $\mathrm{D}_{2} \mathrm{O}$ ) $\delta: 8.44$ (s, $\left.1 \mathrm{H}, \mathrm{H}-8\right), 8.15$ (s, $\left.1 \mathrm{H}, \mathrm{H}-2\right), 6.41$ (apparent t, $1 \mathrm{H}, J_{1^{\prime}, 2^{\prime} \mathrm{a}}$ $\left.=J_{1^{\prime}, 2^{\prime} \mathrm{b}}=7 \mathrm{~Hz}, \mathrm{H}-1^{\prime}\right), 4.64-4.60$ (m, 1H, H-3'), 4.22-4.17 (m, 1H, H-4'), 3.94-3.83 (m, 2H, H-5', $\mathrm{H}-5 "$ ), 3.70-3.61 (m, 1H, H- $\alpha$ ), 2.77-2.70 (m, 1H, H-2'a), 2.52-2.32 (m, 3H, H-2'b \& H- $\beta$ ). ${ }^{13} \mathrm{C}$ NMR (125 MHz, $\left.\mathrm{D}_{2} \mathrm{O}\right) \delta: 181.9 \& 180.1$ ( $\alpha \& \beta$ CO), 156.1 (C-6), 153.1(C-2), 149.2 (C-4), 140.4 (C-8), 119.1 (C-5), 86.6 (C-4'), 84.0 (C-1'), 71.8 (C-3'), 64.4 (C-5'), 55.5 (C- $\alpha), 43.8$ (C- $\beta$ ), 39.5 (C-2') ${ }^{31} \mathrm{P}$ NMR $\left(202 \mathrm{MHz}, \mathrm{D}_{2} \mathrm{O}\right) \delta$ : 6.96. ES-MS calculated for $\mathrm{C}_{14} \mathrm{H}_{19} \mathrm{~N}_{6} \mathrm{O}_{9} \mathrm{P}, 446.31$; found (negative mode) $445.2[\mathrm{M}-\mathrm{H}]^{-}$.

2'-Deoxyadenosine-5'-methylglycinyl phosphoramidate (2a): $\mathrm{TLC}\left(\mathrm{iPrOH} / \mathrm{H}_{2} \mathrm{O} / \mathrm{NH}_{3}, 7: 1: 2\right)$ : $\mathrm{R}_{f}=0.49 .{ }^{1} \mathrm{H}$ NMR (500 MHz, MeOD) $\delta: 8.53(\mathrm{~s}, 1 \mathrm{H}, \mathrm{H}-8), 8.22$ (s, 1H, H-2), 6.53-6.50 (m, 1H, H-1'), 4.67-4.64 (m, 1H, H-3'), 4.16-4.14 (m, 1H, H-4'), 4.07-4.02 (m, 2H, H-5', H-5"), 3.64 (s, 3H, $\left.\mathrm{CH}_{3}\right), 3.58$ (d, 2H, $\left.J_{\mathrm{H \alpha}-\mathrm{P}}=10 \mathrm{~Hz}, \mathrm{H}-\alpha\right), 2.85-2.79$ (m, 1H, H-2'a), 2.49-2.44 (m, 1H, H-2'b). ${ }^{13} \mathrm{C}$ NMR (125 MHz, MeOD) $\delta: 175.5$ (CO), 158.1 (C-6), 154.6 (C-2), 151.3 (C-4), 141.9 (C-8), 121.0 (C-5), 88.9 (C-4'), 86.3 (C-1'), 74.0 (C-3'), 66.4 (C-5'), 53.1 (-COOCH$\left.{ }_{3}\right), 45.2$ $(\mathrm{C}-\alpha), 42.2\left(\mathrm{C}-2^{\prime}\right) .{ }^{31} \mathrm{P}$ NMR (202 MHz, MeOD) $\delta$ : 6.63. ES-MS calculated for $\mathrm{C}_{13} \mathrm{H}_{19} \mathrm{~N}_{6} \mathrm{O}_{7} \mathrm{P}$, 402.30; found (negative mode) $401.3[\mathrm{M}-\mathrm{H}]^{-}$. 
2'-Deoxyadenosine-5'-glycinyl phosphoramidate (2): $\mathrm{TLC}\left(\mathrm{iPrOH} / \mathrm{H}_{2} \mathrm{O} / \mathrm{NH}_{3}, 7: 1: 2\right): \mathrm{R}_{f}=$ $0.31 .{ }^{1} \mathrm{H}$ NMR $\left(500 \mathrm{MHz}, \mathrm{D}_{2} \mathrm{O}\right) \delta: 8.36$ (s, $\left.1 \mathrm{H}, \mathrm{H}-8\right), 8.10$ (s, $\left.1 \mathrm{H}, \mathrm{H}-2\right), 6.39$ (apparent t, $1 \mathrm{H}, J_{1^{\prime}, 2^{\prime} \mathrm{a}}$ $\left.=J_{1^{\prime}, 2^{\prime} \mathrm{b}}=5 \mathrm{~Hz}, \mathrm{H}-1^{\prime}\right), 4.62-4.61\left(\mathrm{~m}, 1 \mathrm{H}, \mathrm{H}-3^{\prime}\right), 4.22-4.16\left(\mathrm{~m}, 1 \mathrm{H}, \mathrm{H}-4^{\prime}\right), 3.95-3.89$ (m, 2H, H-5', $\left.\mathrm{H}-5^{\prime \prime}\right), 3.29\left(\mathrm{~d}, 2 \mathrm{H}, J_{\mathrm{H}-\mathrm{P}}=8.7 \mathrm{~Hz}, \mathrm{H}-\alpha\right), 2.77-2.72\left(\mathrm{~m}, 1 \mathrm{H}, \mathrm{H}-2^{\prime} \mathrm{a}\right), 2.55-2.50\left(\mathrm{~m}, 1 \mathrm{H}, \mathrm{H}-2^{\prime} \mathrm{b}\right) .{ }^{13} \mathrm{C}$

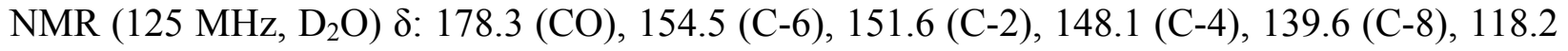
(C-5), 85.7 (C-4'), 83.4 (C-1'), 71.0 (C-3'), 63.7 (C-5'), 44.4 (C- $\alpha), 38.7$ (C-2'). ${ }^{31}$ P NMR (202 $\left.\mathrm{MHz}, \mathrm{D}_{2} \mathrm{O}\right) \delta: 8.13$. ES-MS calculated for $\mathrm{C}_{12} \mathrm{H}_{17} \mathrm{~N}_{6} \mathrm{O}_{7} \mathrm{P}, 388.27$; found (negative mode) 387.3 $[\mathrm{M}-\mathrm{H}]^{-}$.

2'-Deoxyadenosine-5'-methyl- $\boldsymbol{\beta}$-alaninyl phosphoramidate (3a): TLC (iPrOH/ $\mathrm{H}_{2} \mathrm{O} / \mathrm{NH}_{3}$, 7:1:2): $\mathrm{R}_{f}=0.55 .{ }^{1} \mathrm{H}$ NMR (500 MHz, MeOD) $\delta: 8.54$ (s, 1H, H-8), 8.23 (s, 1H, H-2), 6.52 (apparent t, $\left.1 \mathrm{H}, J_{1^{\prime}, 2^{\prime} \mathrm{a}}=J_{1^{\prime}, 2^{\prime} \mathrm{b}}=7 \mathrm{~Hz}, \mathrm{H}-1^{\prime}\right), 4.68-4.66\left(\mathrm{~m}, 1 \mathrm{H}, \mathrm{H}-3^{\prime}\right), 4.18-4.13\left(\mathrm{~m}, 1 \mathrm{H}, \mathrm{H}-4^{\prime}\right)$, 4.02-3.96 (m, 2H, H-5' \& H-5"), 3.63 (s, 3H, CH CH$_{3}, 3.14-3.10$ (m, 2H, H- $\alpha$ ), 2.84-2.80 (m, 1H,

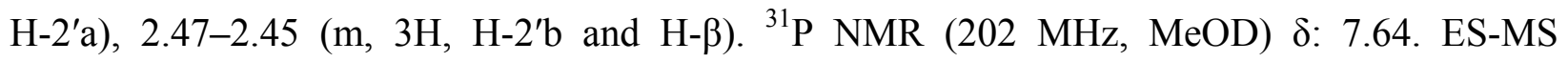
calculated for $\mathrm{C}_{14} \mathrm{H}_{21} \mathrm{~N}_{6} \mathrm{O}_{7} \mathrm{P}, 416.33$, found (negative mode) $415.3[\mathrm{M}-\mathrm{H}]^{-}$.

2'-Deoxyadenosine-5'- $\boldsymbol{\beta}$-alaninyl phosphoramidate (3): $\mathrm{TLC}\left(\mathrm{iPrOH} / \mathrm{H}_{2} \mathrm{O} / \mathrm{NH}_{3}, 7: 1: 2\right): \mathrm{R}_{f}=$ 0.33. ${ }^{1} \mathrm{H}$ NMR (500 MHz, $\left.\mathrm{D}_{2} \mathrm{O}\right) \delta: 8.41(\mathrm{~s}, 1 \mathrm{H}, \mathrm{H}-8), 8.21(\mathrm{~s}, 1 \mathrm{H}, \mathrm{H}-2), 6.45$ (apparent t, $1 \mathrm{H}$, $\left.J_{1^{\prime}, 2^{\prime} \mathrm{a}}=J_{1^{\prime}, 2^{\prime} \mathrm{b}}=6.7 \mathrm{~Hz}, \mathrm{H}-1^{\prime}\right), 4.68-4.66\left(\mathrm{~m}, 1 \mathrm{H}, \mathrm{H}-3^{\prime}\right), 4.23-4.19\left(\mathrm{~m}, 1 \mathrm{H}, \mathrm{H}-4^{\prime}\right), 3.90-3.88(\mathrm{~m}$, 2H, H-5' \& H-5"), 2.85-2.80 (m, 3H, H- $\alpha$ \& H-2'a), 2.58-2.53 (m, 1H, H-2'b), 2.27-2.24 (m, 2H, H- $\beta$ ). ${ }^{13} \mathrm{C}$ NMR (125 MHz, $\mathrm{D}_{2} \mathrm{O}$ ) $\delta: 177.9$ (CO), 154.3 (C-6), 151.0 (C-2), 148.4 (C-4), 139.9 (C-8), 118.5 (C-5), 85.7 (C-4'), 83.5 (C-1'), 70.9 (C-3'), 63.6 (C-5'), 38.5 (C-2'), 37.1 \& 36.9 (C$\alpha \& C-\beta) .{ }^{31} \mathrm{P}$ NMR $\left(121 \mathrm{MHz}, \mathrm{D}_{2} \mathrm{O}\right) \delta: 8.60$. ES-MS calculated for $\mathrm{C}_{13} \mathrm{H}_{19} \mathrm{~N}_{6} \mathrm{O}_{7} \mathrm{P}, 402.30$; found (negative mode) $401.3[\mathrm{M}-\mathrm{H}]^{-}$.

Thymidine-5'-dimethoxyaspartyl phosphoramidate (4a): $\mathrm{TLC}\left(\mathrm{iPrOH} / \mathrm{H}_{2} \mathrm{O} / \mathrm{NH}_{3}, 7: 1: 2\right): \mathrm{R}_{f}=$ 0.50. ${ }^{1} \mathrm{H}$ NMR (500 MHz, MeOD) $\delta: 7.84(\mathrm{~s}, 1 \mathrm{H}, \mathrm{H}-6), 6.36\left(\mathrm{dd}, 1 \mathrm{H}, J_{1^{\prime}, 2^{\prime} \mathrm{a}}=8.01 \mathrm{~Hz}, J_{1^{\prime}, 2^{\prime} \mathrm{b}}=\right.$ $\left.6.05 \mathrm{~Hz}, \mathrm{H}-1^{\prime}\right), 4.50-4.49$ (m, 1H, H-3'), 4.17-4.11 (m, 1H, H- 2 )), 4.05-3.99 (m, 3H, H-4' \& H5', H-5"), 3.72 (s, 3H, $\mathrm{CH}_{3}$ ), 3.65 (s, 3H, $\mathrm{CH}_{3}$ ), 2.90-2.80 (m, 2H, H- $\beta$ ), 2.35-2.19 (m, 2H, H-2', $\left.\mathrm{H}-2^{\prime \prime}\right), 1.95$ (s, 3H, $\left.\mathrm{CH}_{3}-5\right) .{ }^{13} \mathrm{C} \mathrm{NMR}(125 \mathrm{MHz}, \mathrm{MeOD}) \delta: 176.0 \& 173.9$ ( $\left.\alpha \& \beta \mathrm{CO}\right), 167.4(\mathrm{C}-$ 4), 153.4 (C-2), 139.1 (C-6), 112.8 (C-5), 88.6 (C-4'), 87.0 (C-1'), 73.8 (C-3'), 66.3 (C-5'), 53.7 
$(\mathrm{C}-\alpha), 53.6\left(\mathrm{COOC}_{3}\right), 53.0\left(\mathrm{COOCH}_{3}\right), 41.7\left(\mathrm{C}-2^{\prime}\right), 40.8(\mathrm{C}-\beta), 13.4\left(\mathrm{CH}_{3}-5\right) \cdot{ }^{31} \mathrm{P}$ NMR $(121$ $\mathrm{MHz}, \mathrm{MeOD}) \delta$ : 4.81. ES-MS calculated for $\mathrm{C}_{16} \mathrm{H}_{24} \mathrm{~N}_{3} \mathrm{O}_{11} \mathrm{P}, 465.35$; found (negative mode) $464.4[\mathrm{M}-\mathrm{H}]^{-}$.

Thymidine-5'-aspartyl phosphoramidate (4): $\mathrm{TLC}\left(\mathrm{iPrOH} / \mathrm{H}_{2} \mathrm{O} / \mathrm{NH}_{3}, 7: 1: 2\right): \mathrm{R}_{f}=0.30 .{ }^{1} \mathrm{H}$ NMR (500 MHz, $\left.\mathrm{D}_{2} \mathrm{O}\right) \delta: 7.73$ (s, 1H, H-6), 6.27 (apparent t, 1H, $\left.J_{1^{\prime}, 2^{\prime} \mathrm{a}}=J_{1^{\prime}, 2^{\prime} \mathrm{b}}=6.6 \mathrm{~Hz}, \mathrm{H}-1^{\prime}\right)$, 4.50-4.48 (m, 1H, H-3'), 4.08-4.08 (m, 1H, H-4'), 3.92-3.89 (m, 2H, H-5', H-5'), 3.73-3.69 (m, $1 \mathrm{H}, \mathrm{H}-\alpha), 2.53-2.41$ (m, 2H, H- $\beta$ ), 2.33-2.23 (m, 2H, H-2', H-2"), 1.86 (s, 3H, $\left.\mathrm{CH}_{3}-5\right) .{ }^{13} \mathrm{C}$ NMR $\left(125 \mathrm{MHz}, \mathrm{D}_{2} \mathrm{O}\right) \delta: 180.6 \& 178.7$ ( $\alpha \& \beta \mathrm{CO}$ ), 166.2 (C-4), 151.4 (C-2), 137.1 (C-6), 111.4 (C5), 85.4 (C-4'), 84.6 (C-1'), 70.9 (C-3'), 63.7 (C-5'), 54.3 (C- $\alpha), 42.5$ (C- $\beta$ ), 38.2 (C-2'), 11.3 $\left(\mathrm{CH}_{3}-5\right) .{ }^{31} \mathrm{P}$ NMR $\left(202 \mathrm{MHz}, \mathrm{D}_{2} \mathrm{O}\right)$ 8: 6.49. ES-MS calculated for $\mathrm{C}_{14} \mathrm{H}_{20} \mathrm{~N}_{3} \mathrm{O}_{11} \mathrm{P}, 437.30$; found negative mode) $436.2[\mathrm{M}-\mathrm{H}]^{-}$.

Thymidine-5'-methylglycinyl phosphoramidate (5a): $\mathrm{TLC}\left(\mathrm{iPrOH} / \mathrm{H}_{2} \mathrm{O} / \mathrm{NH}_{3}, 7: 1: 2\right): \mathrm{R}_{f}=$ 0.58. ${ }^{1} \mathrm{H}$ NMR (300 MHz, MeOD) $\delta: 7.80(\mathrm{~s}, 1 \mathrm{H}, \mathrm{H}-6), 6.35$ (apparent t, $1 \mathrm{H}, J_{1^{\prime}, 2^{\prime} \mathrm{a}}=J_{1^{\prime}, 2^{\prime} \mathrm{b}}=6.5$ $\left.\mathrm{Hz}, 1 \mathrm{H}, \mathrm{H}-1^{\prime}\right), 4.48-4.47$ (m, 1H, H-3'), 4.04-4.03 (m, 3H, H-4', H-5' \& H-5"), 3.70 (s, 3H, $\mathrm{CH}_{3}$ ), 3.33 (s, 2H, H- $\alpha$ ), 2.36-2.17 (m, 2H, H-2' \& H-2"), 1.95 (s, 3H, $\left.\mathrm{CH}_{3}-5\right) .{ }^{31} \mathrm{P}$ NMR (121 $\mathrm{MHz}, \mathrm{MeOD}$ ) $\delta$ : 5.66. ES-MS calculated for $\mathrm{C}_{13} \mathrm{H}_{20} \mathrm{~N}_{3} \mathrm{O}_{9} \mathrm{P}, 393.29$; found (negative mode) 392.2 $[\mathrm{M}-\mathrm{H}]^{-}$.

Thymidine-5'-glycinyl phosphoramidate (5): $\mathrm{TLC}\left(\mathrm{iPrOH} / \mathrm{H}_{2} \mathrm{O} / \mathrm{NH}_{3}, 7: 1: 2\right): \mathrm{R}_{f}=0.33 .{ }^{1} \mathrm{H}$ NMR (500 MHz, $\left.\mathrm{D}_{2} \mathrm{O}\right) \delta: 7.69$ (s, 1H, H-6), 6.28 (apparent t, $\left.1 \mathrm{H}, J_{1^{\prime}, 2^{\prime} \mathrm{a}}=J_{1^{\prime}, 2^{\prime} \mathrm{b}}=6.9 \mathrm{~Hz}, \mathrm{H}-1^{\prime}\right)$, 4.49-4.47 (m, 1H, H-3'), 4.11-4.08 (m, 1H, H-4'), 3.94-3.93 (m, 2H, H-5' and H-5"), 3.37 (d, $\left.J_{\mathrm{H \alpha}-\mathrm{P}}=8.6 \mathrm{~Hz}, 2 \mathrm{H}, \mathrm{H}-\alpha\right), 2.31-2.28\left(\mathrm{~m}, 2 \mathrm{H}, \mathrm{H}-2^{\prime} \& \mathrm{H}-2^{\prime \prime}\right), 1.87$ (s, 3H, $\left.\mathrm{CH}_{3}-5\right) .{ }^{31} \mathrm{P}$ NMR (202 $\mathrm{MHz}, \mathrm{D}_{2} \mathrm{O}$ ) $\delta$ : 7.99. ES-MS calculated for $\mathrm{C}_{12} \mathrm{H}_{18} \mathrm{~N}_{3} \mathrm{O}_{9} \mathrm{P}, 379.26$; found (negative mode) 378.2 $[\mathrm{M}-\mathrm{H}]^{-}$.

Thymidine-5'-methyl- $\boldsymbol{\beta}$-alaninyl phosphoramidate (6a): $\mathrm{TLC}\left(\mathrm{iPrOH} / \mathrm{H}_{2} \mathrm{O} / \mathrm{NH}_{3}, 7: 1: 2\right): \mathrm{R}_{f}=$ 0.60. ${ }^{1} \mathrm{H}$ NMR (300 MHz, MeOD) $\delta: 7.83$ (s, $1 \mathrm{H}, \mathrm{H}-6$ ), 6.37 (apparent t, $1 \mathrm{H}, J_{1^{\prime}, 2^{\prime} \mathrm{a}}=J_{1^{\prime}, 2^{\prime} \mathrm{b}}=6.4$ Hz, H-1'), 4.51-4.49 (m, 1H, H-3'), 4.04-3.99 (m, 3H, H-4', H-5' \& H-5"), 3.66 (s, 3H, $\mathrm{CH}_{3}$ ), 3.19-3.11 (m, 2H, H- $\alpha), 2.54$ (t, $\left.J_{\mathrm{H} \beta-\mathrm{H} \alpha}=6.7 \mathrm{~Hz}, 2 \mathrm{H}, \mathrm{H}-\beta\right), 2.38-2.30$ (m, 2H, H-2' \& H-2"), 1.95 
(s, 3H, $\left.\mathrm{CH}_{3}-5\right) .{ }^{31} \mathrm{P}$ NMR (121 MHz, MeOD) $\delta:$ 6.92. ES-MS calculated for $\mathrm{C}_{14} \mathrm{H}_{22} \mathrm{~N}_{3} \mathrm{O}_{9} \mathrm{P}$, 407.31; found (negative mode) $406.6[\mathrm{M}-\mathrm{H}]^{-}$.

Thymidine-5'- $\boldsymbol{\beta}$-alaninyl phosphoramidate (6): $\mathrm{TLC}\left(\mathrm{iPrOH} / \mathrm{H}_{2} \mathrm{O} / \mathrm{NH}_{3}, 7: 1: 2\right): \mathrm{R}_{f}=0.30 .{ }^{1} \mathrm{H}$ NMR (500 MHz, D $2 \mathrm{O}) \delta: 7.67$ (s, 1H, H-6), 6.25 (apparent t, $1 \mathrm{H}, J_{1^{\prime}, 2^{\prime} \mathrm{a}}=J_{1^{\prime}, 2^{\prime} \mathrm{b}}=6.9 \mathrm{~Hz}, 1 \mathrm{H}, \mathrm{H}-$ 1'), 4.48-4.43 (m, 1H, H-3'), 4.07-4.02 (m, 1H, H-4'), 3.91-3.82 (m, 2H, H-5' \& H-5"), 2.932.89 (m, 2H, H- $\alpha$ ), 2.29-2.24 (m, 4H, H-2', H-2" \& H- $\beta$ ), 1.81 (s, 3H, $\left.\mathrm{CH}_{3}-5\right) .{ }^{31} \mathrm{P}$ NMR (202 $\mathrm{MHz}, \mathrm{D}_{2} \mathrm{O}$ ) $\delta:$ 8.65. ES-MS calculated for $\mathrm{C}_{13} \mathrm{H}_{20} \mathrm{~N}_{3} \mathrm{O}_{9} \mathrm{P}, 393.29$; found (negative mode) 392.3 $[\mathrm{M}-\mathrm{H}]^{-}$.

\section{$\underline{\text { Synthesis of 2-deoxy-3,5-di- } O \text {-p-toluoyl- } \alpha \text {-D-ribofuranosyl chloride, } 10 \text { (Scheme S1) }}$}

1- $\boldsymbol{O}$-methyl-2-deoxy- $\boldsymbol{\alpha} / \boldsymbol{\beta}$-D-ribofuranose (8): To a solution of 2-deoxy- $\alpha / \beta$-D-ribose, 7 (10.0 $\mathrm{g}, 74.6 \mathrm{mmol}$ ) in $180.0 \mathrm{~mL}$ of anhydrous methanol, $6.4 \mathrm{~mL}$ of $1.25 \mathrm{M} \mathrm{HCl}$ in $\mathrm{MeOH}$ was added to get $8.00 \mathrm{mmol}$ of hydrochloric acid in the reaction mixture. The reaction mixture was kept for 10 minutes at room temperature. After addition of $9.4 \mathrm{~g}$ of $\mathrm{MgCO}_{3}$, the suspension was filtered, and the filtrate was evaporated with silica gel and purified on a silica gel column eluted with $\mathrm{CH}_{2} \mathrm{Cl}_{2} / \mathrm{MeOH}$ (98:2 to $\left.96: 4\right)$ to give 1-O-methyl-2-deoxy- $\alpha / \beta$-D-ribofuranose (8) as a syrup (88\%).TLC (DCM/MeOH, 9:1): $\mathrm{R}_{f}=0.35 .{ }^{1} \mathrm{H}$ NMR $\left(600 \mathrm{MHz}, \mathrm{CDCl}_{3}\right) \delta: 5.06-5.02(\mathrm{~m}, 2 \mathrm{H}, \mathrm{H}-$ 1 (a \& b)), 4.48-4.35 (m, 1H, H-3 (a or b)), 4.13-4.11 (m, 1H, H-3 (a or b)), 4.03-4.01 (m, 1H, H-4 (a or b)), 3.96-3.93 (m, 1H, H-4 (a or b)), 3.70-3.58 (m, 4H, H-5, ((a \& b)), 3.34 (s,3H, $\mathrm{OCH}_{3}$ (a or b)), 3.32 (s, 3H, $\mathrm{OCH}_{3}$ (a or b)), 2.20-2.03 (m, 4H, H-2 (a or b)). ${ }^{13} \mathrm{C}$ NMR (150 $\left.\mathrm{MHz}, \mathrm{CDCl}_{3}\right) \delta: 105.4 \& 105.3$ (C-1 (a \& b)), $86.9 \& 86.5$ (C-4 (a \& b)), $72.2 \& 71.7$ (C-3 (a \& b)), $63.6 \& 62.5$ (C-5 (a \& b)), $55.3 \& 54.9$ (OMe (a \& b)), $41.8 \& 41.2$ (C-2 (a \& b)). ES-MS calculated for $\mathrm{C}_{6} \mathrm{H}_{12} \mathrm{O}_{4}, 148.2$; found (positive mode) $148.9[\mathrm{M}+\mathrm{H}]^{+}$.

1- $O$-methyl-2-deoxy-3,5-di- $\boldsymbol{O}$-p-toluoyl- $\alpha / \boldsymbol{\beta}$-D-ribofuranose (9): To a soluiton of 1-O-methyl2-deoxy- $\alpha / \beta$-D-ribofuranose (8) $(9.7 \mathrm{~g}, 65.5 \mathrm{mmol})$ in dry acetone $(110.0 \mathrm{~mL}), p$-toluoyl chloride $(17.5 \mathrm{~mL}, 130.9 \mathrm{mmol})$ was added. $\mathrm{Et}_{3} \mathrm{~N}(20.0 \mathrm{~mL})$ was added slowly and the solution was stirred overnight. After filtering $\mathrm{Et}_{3} \mathrm{~N}$.HCl, the filtrate was evaporated. The crude product was purified by flash chromatography eluting with hexane first and then with hexane-EtOAc 
(15:1) to afford 1-O-methyl-2-deoxy-3,5-di- $O$ - $p$-toluoyl- $\alpha / \beta$-D-ribofuranose $(\mathbf{9}, 67.0 \%)$. TLC (Hexane/EtOAc, 15:1): $\mathrm{R}_{f}=0.24 .{ }^{1} \mathrm{H}$ NMR $\left(500 \mathrm{MHz}, \mathrm{CH}_{3} \mathrm{COCH}_{3}-\mathrm{d}_{6}\right) \delta: 7.97$ (d, 2H, $J=8.1$ $\mathrm{Hz}$, aromatic-H), $7.92(\mathrm{~d}, 2 \mathrm{H}, J=8.1 \mathrm{~Hz}$, aromatic-H), $7.32(\mathrm{~d}, 2 \mathrm{H}, J=8.1 \mathrm{~Hz}$, aromatic-H), 7.30 (d, 2H, $J=8.1 \mathrm{~Hz}$, aromatic-H), 5.62-5.59 (m, 1H, H-1), 5.25-5.24 (m, 1H, H-3), 4.564.42 (m, 3H, H-4 \& H-5), 3.33 (s, 3H, $-\mathrm{OCH}_{3}$ ), 2.54-2.50 (m, 2H, H-2), 2.41 (s, 3H, aromatic$\left.\mathrm{CH}_{3}\right), 2.40\left(\mathrm{~s}, 3 \mathrm{H}\right.$, aromatic- $\left.\mathrm{CH}_{3}\right) .{ }^{13} \mathrm{C} \mathrm{NMR}\left(125 \mathrm{MHz}, \mathrm{CH}_{3} \mathrm{COCH}_{3}-\mathrm{d}_{6}\right) \delta: 166.3,166.1 \& 166.0$ (-CO), 144.5-129.6 \& 127.8-127.5 (aromatic ring-C), 105.8 \& 105.4 (C-1), $81.9 \& 81.4$ (C-4), $75.8 \& 75.2(\mathrm{C}-3), 65.4 \& 64.8(\mathrm{C}-5), 54.9 \& 54.8\left(-\mathrm{OCH}_{3}\right), 39.2 \& 39.1(\mathrm{C}-2), 21.3$ (aromatic$\left.\mathrm{CH}_{3}\right)$. ES-MS calculated for $\mathrm{C}_{22} \mathrm{H}_{24} \mathrm{O}_{6}, 384.16$; found $407.0[\mathrm{M}+\mathrm{Na}]^{+}$.

2-Deoxy-3,5-di- $O$-p-toluoyl- $\alpha$-D-ribofuranosyl chloride (10): 1-O-methyl-2-deoxy-3,5-di- $O$ - $p$ toluoyl- $\alpha / \beta$-D-ribofuranose (9) (16.9 g, $43.99 \mathrm{mmol})$ was dissolved in dry ether $(154.0 \mathrm{~mL})$ and the solution was cooled to $0^{\circ} \mathrm{C}$ in an ice bath. To the solution was bubbled $\mathrm{HCl}$ gas for $c a .20$ minutes until the mixture crystallized. The reaction mixture was then kept in a refrigerator $\left(+4^{\circ} \mathrm{C}\right)$ overnight. The precipitate was filtered and washed with cold ether. The solid was immediately dried under vacuum over $\mathrm{NaOH}$ to give 2-deoxy-3,5-di- $O$ - $p$-toluoyl- $\alpha$-Dribofuranosyl chloride (10) as a colourless crystalline powder $(75 \%) .{ }^{1} \mathrm{H} \mathrm{NMR}\left(500 \mathrm{MHz}, \mathrm{CDCl}_{3}\right)$ $\delta: 7.9$ (d, $2 \mathrm{H}, J=8.2 \mathrm{~Hz}$, aromatic-H), 7.89 (d, 2H, $J=8.2 \mathrm{~Hz}$, aromatic-H), 7.27-7.23 (m, oberlapping with $\mathrm{CHCl}_{3}$ signal, $4 \mathrm{H}$, aromatic-H), $6.48\left(\mathrm{~d}, 1 \mathrm{H}, J_{1,2}=5.1 \mathrm{~Hz}, \mathrm{H}-1\right), 5.56-5.55(\mathrm{~m}$, 1H, H-3), 4.87-4.85 (m, 1H, H-4), 4.69-4.58 (m, 2H, H-5), 2.89-2.72 (m, 2H, H-2), 2.42 (s, 3H, aromatic- $\left.\mathrm{CH}_{3}\right), 2.41\left(\mathrm{~s}, 3 \mathrm{H}\right.$, aromatic- $\left.\mathrm{CH}_{3}\right) .{ }^{13} \mathrm{C} \mathrm{NMR}\left(75 \mathrm{MHz}, \mathrm{CDCl}_{3}\right) \delta: 166.4 \& 166.3(-\mathrm{CO})$, 144.3, 144.0, 130.2-129.2, 126. 9 \& 126.7 (aromatic ring-C), 95.3 (C-1), 84.7 (C-4), 73.6 (C-3), 63.5 (C-5), 44.5 (C-2), 21.7 (aromatic- $\mathrm{CH}_{3}$ ). ES-MS calculated for $\mathrm{C}_{21} \mathrm{H}_{21} \mathrm{ClO}_{5}, 388.11$; found (positive mode) $389.9[\mathrm{M}+\mathrm{H}]^{+}$. 


\section{$\underline{\text { Synthesis of 1-deazaadenine analogues (Scheme S2) }}$}

3H-imidazo[4,5-b]pyridine (12): A mixture of 2,3-diaminopyridine, 12 (25 g, $229.08 \mathrm{mmol})$ and triehtylorthoformate $(500 \mathrm{~mL}, 3.0 \mathrm{~mol})$ was refluxed for 3 hours at $145^{\circ} \mathrm{C}$. The solution was evaporated to dryness in rotary evaporator and then the residue was dissolved in $500 \mathrm{~mL}$ of $99 \%$ formic acid and refluxed for 2 hours at $110^{\circ} \mathrm{C}$. When the reaction was completed, the excess formic acid was removed with the rotary evaporator and the residue dissolved in $500 \mathrm{~mL}$ absolute methanol, treated with activated charcoal and stirred overnight at room temperature. Then the charcoal was removed by vacuum filtration through Celite 545 and the filtrate was evaporated to obtain $3 H$-imidazo[4,5-b]pyridine (12) as a white solid (99\%). TLC $\left(\mathrm{CHCl}_{3} / \mathrm{MeOH}, 9: 1\right): \mathrm{R}_{f}=0.23 .{ }^{1} \mathrm{H}-\mathrm{NMR}\left(500 \mathrm{MHz}, \mathrm{DMSO}-\mathrm{d}_{6}\right) \delta: 13.01$ (br s, 1H, -NH, exchangeable with $\left.\mathrm{D}_{2} \mathrm{O}\right), 8.41(\mathrm{~s}, 1 \mathrm{H}, \mathrm{H}-2), 8.35\left(\mathrm{~d}, 1 \mathrm{H}, J_{5,6}=4.7 \mathrm{~Hz}, \mathrm{H}-5\right), 8.01\left(\mathrm{~d}, 1 \mathrm{H}, J_{7,6}=\right.$ $8.0 \mathrm{~Hz}, \mathrm{H}-7), 7.23$ (dd, 1H, $\left.J_{6,5}=4.7 \mathrm{~Hz}, J_{6,7}=8.0 \mathrm{~Hz}, \mathrm{H}-6\right) .{ }^{13} \mathrm{C}\left(125 \mathrm{MHz}, \mathrm{DMSO}-\mathrm{d}_{6}\right) \delta: 144.0$, 143.8, 117.8 (other carbon peaks are overlapped with the mentioned carbon peaks). ES-MS calculated for $\mathrm{C}_{6} \mathrm{H}_{5} \mathrm{~N}_{3}, 119.05$; found (positive mode) $120.1[\mathrm{M}+\mathrm{H}]^{+}$.

3H-imidazo[4,5-b]pyridine- $\boldsymbol{N}$-oxide (13): To a solution of $3 H$-imidazo[4,5-b]pyridine (12) (27.12 g, $227.7 \mathrm{mmol})$ in 99\% acetic acid (396 mL), meta-chloroperbenzoic acid (84.19 g, 341.5 mmol) was added. The mixture was stirred over the weekend at room temperature. Precipitate was filtered under vacuum. The solid was washed three times with ethyl acetate and dried in vacuo. Since NMR results confirmed the presence of meta-chlorobenzoic acid, the solid was refluxed in ethyl acetate $(300 \mathrm{~mL})$ for 30 minutes and filtered. The crude product was purified by recrystallization from ethanol to provide $3 H$-imidazo[4,5-b]pyridine- $N$-oxide (13) as whitebrown solid (60\%). TLC ( $\left.\mathrm{CHCl}_{3} / \mathrm{MeOH}, 9: 1\right): \mathrm{R}_{f}=0.11 .{ }^{1} \mathrm{H}$ NMR (500 MHz, DMSO-d 6 ) $\delta: 8.38$ $(\mathrm{s}, 1 \mathrm{H}, \mathrm{H}-2), 8.17$ (d, $\left.1 \mathrm{H}, J_{5,6}=6.4 \mathrm{~Hz}, \mathrm{H}-5\right), 7.59$ (d, 1H, $\left.J_{7,6}=8.0 \mathrm{~Hz}, \mathrm{H}-7\right), 7.19$ (dd, $1 \mathrm{H}, J_{6,5}=$ $\left.6.4 \mathrm{~Hz}, J_{6,7}=8.0 \mathrm{~Hz}, \mathrm{H}-6\right) .{ }^{13} \mathrm{C}\left(125 \mathrm{MHz}, \mathrm{DMSO}_{-} \mathrm{d}_{6}\right) \delta: 143.4,132.9,119.0$ (other carbon peaks are overlapped with the mentioned carbon peaks). ES-MS calculated for $\mathrm{C}_{6} \mathrm{H}_{5} \mathrm{~N}_{3} \mathrm{O}, 135.12$; found (negative mode) $133.8[\mathrm{M}-\mathrm{H}]^{-}$.

7-Nitroimidazo[4,5-b]pyridine- $N$-oxide (14): To a solution of $3 H$-imidazo[4,5-b]pyridine- $N$ oxide (13) $(14.12 \mathrm{~g}, 104.5 \mathrm{mmol})$ in trifluoroacetic acid $(104.0 \mathrm{~mL})$ at $0^{\circ} \mathrm{C}, 90 \%$ fuming nitric acid $(68 \mathrm{~mL})$ was added in a drop wise manner. The mixture was heated at $90^{\circ} \mathrm{C}$ for 4 hours, cooled down, and then poured on to crushed ice. The mixture was neutralized slowly with 
concentrated ammonium hydroxide while maintaining the temperature around $30^{\circ} \mathrm{C}$. The resulting solid was filtered, washed with ice cold water, and dried to obtain 7-nitroimidazo[4,5$b]$ pyridine- $N$-oxide (14) as yellow solid (63\%). TLC (iPrOH/NH$\left./ \mathrm{NH}_{3} / \mathrm{H}_{2} \mathrm{O}, 7: 1: 1\right): \mathrm{R}_{f}=0.54 .{ }^{1} \mathrm{H}$ NMR (500 MHz, DMSO-d ${ }_{6}$ ) $\delta: 13.9$ (br s, $1 \mathrm{H},-\mathrm{NH}$ exchangeable with $\mathrm{D}_{2} \mathrm{O}$ ), 8.58 (s, 1H, H-2), $8.31\left(\mathrm{~d}, 1 \mathrm{H}, J_{5,6}=7.15 \mathrm{~Hz}, \mathrm{H}-5\right), 8.07$ (d, $\left.1 \mathrm{H}, J_{6,5}=7.15 \mathrm{~Hz}, \mathrm{H}-6\right) .{ }^{13} \mathrm{C}$ NMR (125 MHz, DMSOd $\left.\mathrm{d}_{6}\right)$ : 149.3 (C-3a), 145.9 (C-2), 133.5 (C-5), 129.8 (C-7), 123.3 (C-7a), 115.3 (C-6). ES-MS calculated for $\mathrm{C}_{6} \mathrm{H}_{4} \mathrm{~N}_{4} \mathrm{O}_{3}, 180.1$; found (negative mode) $178.9[\mathrm{M}-\mathrm{H}]$.

7-Nitroimidazo[4,5-b]pyridine (15): To a cold solution of 7-nitroimidazo[4,5-b]pyridine- $N$ oxide (14) (8.93 g, $49.6 \mathrm{mmol})$ in dry acetonitrile, (180 mL) phosphorus trichloride $(39.3 \mathrm{~mL})$ was added dropwise and the mixture was kept at $0^{\circ} \mathrm{C}$ for 1.5 hours. Then the solution was poured onto crushed ice and then neutralized with solid sodium carbonate with vigorous stirring. The resulting solid was filtered and chromatographed on silica gel eluting with dichloromethane/methanol/ammonia (9:1:0.1) to obtain 7-nitroimidazo[4,5-b]pyridine (15) as reddish yellow solid (87\%). TLC (DCM/MeOH/NH$, ~ 9: 1: 0.1): ~ \mathrm{R}_{f}=0.55 .{ }^{1} \mathrm{H}$ NMR (500MHz, DMSO-d ${ }_{6}$ ) $\delta: 7.96$ (s, 1H, H-2), 7.88 (d, 1H, $J_{5,6}=7.0 \mathrm{~Hz}, \mathrm{H}-5$ ), 7.68 (d, 1H, $J_{6,5}=7.0 \mathrm{~Hz}, \mathrm{H}-6$ ). ${ }^{13} \mathrm{C}$ NMR (125 MHz, DMSO-d 6 ) $\delta: 157.7$ (C-2), 153.4 (C-3a), 134.8 (C-7a), 132.3 (C-7), 128.2 (C-5), 110.7 (C-6). ES-MS calculated for $\mathrm{C}_{6} \mathrm{H}_{4} \mathrm{~N}_{4} \mathrm{O}_{2}, 164.03$; found (positive mode) 165.0 $[\mathrm{M}+\mathrm{H}]^{+}$.

7-Nitro-3-(2'-deoxy-3',5'-di- $O$-p-toluoyl- $\beta$-D-ribofuranosyl)-imidazo[4,5-b]pyridine (16): To a suspension of 7-nitroimidazo[4,5-b]pyridine $(\mathbf{1 5})(1.0 \mathrm{~g}, 6.1 \mathrm{mmol})$ in dry acetonitrile $(40.0$ $\mathrm{mL})$ under an atmosphere of $\mathrm{Ar}, \mathrm{NaH}(60 \%$ in oil, $0.32 \mathrm{~g}, 6.65 \mathrm{mmol})$ was added and the mixture was stirred at room temperature for $30 \mathrm{~min}$. To the ice cold mixture, 2-deoxy-3,5-di- $O$ - $p$-toluoyl$\alpha$-D-ribofuranosyl chloride (10, $2.7 \mathrm{~g}, 6.9 \mathrm{mmol})$ was added and the suspension was stirred at $0^{\circ} \mathrm{C}$ for $6 \mathrm{~h}$ and then kept at room temperature for overnight. The reaction mixture was filtered to remove the insoluble material and the filtrate was concentrated to a black residue which was chromatographed on a silica gel column eluted with hexane/ EtOAc (7:3) to afford 7-nitro-3-(2'deoxy-3', $5^{\prime}$-di- $O$ - $p$-toluoyl- $\beta$-D-ribofuranosyl)-imidazo[4,5-b]pyridine (16) as a yellow solid (73.4\%). TLC $\left(\mathrm{CHCl}_{3} / \mathrm{CH}_{3} \mathrm{COCH}_{3}, 7: 3\right): \mathrm{R}_{f}=0.3 .{ }^{1} \mathrm{H} \mathrm{NMR}\left(300 \mathrm{MHz}, \mathrm{CDCl}_{3}\right) \delta: 8.58(\mathrm{~d}, 1 \mathrm{H}$, $\left.J_{5,6}=5.3 \mathrm{~Hz}, \mathrm{H}-5\right), 8.52(\mathrm{~s}, 1 \mathrm{H}, \mathrm{H}-2), 8.0\left(\mathrm{~d}, 2 \mathrm{H}, J=8.2 \mathrm{~Hz}\right.$, aromatic-H), $7.97\left(\mathrm{~d}, 1 \mathrm{H}, J_{6,5}=5.3\right.$ Hz, H-6), 7.89 (d, $J=8.2 \mathrm{~Hz}$, aromatic-H), 7.27 (d, 2H, $J=8.1 \mathrm{~Hz}$, aromatic-H), 7.23 (d, 2H, $J=$ 
$8.1 \mathrm{~Hz}$, aromatic-H), $6.71\left(\mathrm{dd}, 1 \mathrm{H}, J_{1^{\prime}, 2^{\prime} \mathrm{a}}=8.1 \mathrm{~Hz}, J_{1^{\prime}, 2^{\prime} \mathrm{b}}=5.9 \mathrm{~Hz}, \mathrm{H}-1^{\prime}\right), 5.88-5.85\left(\mathrm{~m}, 1 \mathrm{H}, \mathrm{H}-3^{\prime}\right)$, 4.84-4.66 (m, 3H, H-4', H-5' \& H-5"), 3.21-3.14 (m, 1H, H-2'a), 2.97-2.90 (m, 1H, H-2'b), 2.47 (s, $3 \mathrm{H}$, aromatic- $\left.\mathrm{CH}_{3}\right), 2.42$ (s, $3 \mathrm{H}$, aromatic- $\mathrm{CH}_{3}$ ). ES-MS calculated for $\mathrm{C}_{27} \mathrm{H}_{24} \mathrm{~N}_{4} \mathrm{O}_{7}, 516.16$; found $538.9[\mathrm{M}+\mathrm{Na}]^{+}$.

7-Nitro-3-(2'-deoxy- $\beta$-D-ribofuranosyl)-imidazo[4,5-b]pyridine (17): A solution of 7-nitro-3(2'-deoxy-3',5'-di- $O$ - $p$-toluoyl- $\beta$-D-ribofuranosyl)-imidazo[4,5-b]pyridine (16) $\quad(2.0$ g, 3.87 $\mathrm{mmol}$ ) in $100 \mathrm{~mL}$ of methanol saturated at $0^{\circ} \mathrm{C}$ with ammonia was set aside at room temperature for overnight. The reaction mixture was evaporated and the residue was chromatographed on a silica gel column eluted with $\mathrm{CHCl}_{3} / \mathrm{MeOH} / \mathrm{NH}_{3}$ (9.4:0.5:0.08) to obtain 7-nitro-3-(2'-deoxy- $\beta$ D-ribofuranosyl)-imidazo[4,5-b]pyridine (17) as yellow solid (91\%). TLC $\left(\mathrm{CHCl}_{3} / \mathrm{MeOH}\right.$, 9.5:0.5): $\mathrm{R}_{f}=0.2 .{ }^{1} \mathrm{H}$ NMR (300 MHz, MeOD) $\delta: 8.97$ (s, $\left.1 \mathrm{H}, \mathrm{H}-2\right), 8.65$ (d, $1 \mathrm{H}, J_{5,6}=5.3 \mathrm{~Hz}$, $\mathrm{H}-5), 8.03\left(\mathrm{~d}, 1 \mathrm{H}, J_{6,5}=5.3 \mathrm{~Hz}, \mathrm{H}-6\right), 6.67$ (apparent t, $\left.1 \mathrm{H}, J_{1^{\prime}, 2^{\prime} \mathrm{a}}=J_{1^{\prime}, 2^{\prime} \mathrm{b}}=6.6 \mathrm{~Hz}, \mathrm{H}-1^{\prime}\right), 4.65-$ 4.61 (m, 1H, H-3'), $4.11-4.07$ (m, 1H, H-4'), 3.89-3.75 (m, 2H, H-5' \& H-5"), 2.90-2.81 (m, $\left.1 \mathrm{H}, \mathrm{H}-2^{\prime} \mathrm{a}\right), 2.59-2.51$ (m, 2H, H-2'b). ES-MS calculated for $\mathrm{C}_{11} \mathrm{H}_{12} \mathrm{~N}_{4} \mathrm{O}_{5}, 280.24$; found 303.1 $[\mathrm{M}+\mathrm{Na}]^{+}$.

7-Amino-3-(2'-deoxy- $\beta$-D-ribofuranosyl)-imidazo[4,5-b]pyridine (mentioned in the article as 2'-deoxy-1-deazaadenosine, 18): To a solution of 7-nitro-3-(2'-deoxy- $\beta$-D-ribofuranosyl)imidazo[4,5-b]pyridine (17) $(0.94 \mathrm{~g}, 3.35 \mathrm{mmol})$ in methanol $(180.0 \mathrm{~mL})$ was added $10 \% \mathrm{Pd} / \mathrm{C}$ $(0.47 \mathrm{~g})$ and ammonium formate $(10.56 \mathrm{~g}, 167.7 \mathrm{mmol})$ and the mixture was refluxed at $75^{\circ} \mathrm{C}$ for $3 \mathrm{~h}$. The catalyst was removed by filtration on celite 545 and the filtrate was evaporated to white solid. The crude product was purified on silica gel column eluting with $\mathrm{CHCl}_{3} / \mathrm{MeOH}(9: 1)$ to obtain 2'-deoxy-1-deazaadenosine (18) as white solid (83\%). TLC $\left(\mathrm{CHCl}_{3} / \mathrm{MeOH}, 9: 1\right): \mathrm{R}_{f}=0.2$. ${ }^{1} \mathrm{H}$ NMR (500 MHz, MeOD) $\delta: 8.25$ (s, 1H, H-2), 7.85 (d, 1H, $\left.J_{5,6}=6.0 \mathrm{~Hz}, \mathrm{H}-5\right), 6.49$ (d, 1H, $\left.J_{6,5}=6.0 \mathrm{~Hz}, \mathrm{H}-6\right), 6.44\left(\mathrm{dd}, 1 \mathrm{H}, J_{1^{\prime}, 2^{\prime} \mathrm{a}}=8.5 \mathrm{~Hz}, J_{1^{\prime}, 2^{\prime} \mathrm{b}}=6.0 \mathrm{~Hz}, \mathrm{H}-1^{\prime}\right), 4.58-4.56\left(\mathrm{~m}, 1 \mathrm{H}, \mathrm{H}-3^{\prime}\right)$, 4.09-4.08 (m, 1H, H-4'), 3.87-3.73 (m, 2H, H-5' \& H-5"), 2.89-2.84 (m, 1H, H-2'a), 2.37-233 (m, 1H, H-2'b). ${ }^{13} \mathrm{C}$ NMR (125 MHz, MeOD) $\delta: 149.1$ (C-7), 147.0 (C-3a), 145.5 (C-5), 141.0 (C-2), 124.8 (C-7a), 104.1 (C-6), 90.1 (C-4'), 87.7 (C-1'), 73.4 (C-3'), 63.9 (C-5'), 41.4 (C-2'). ES-MS calculated for $\mathrm{C}_{11} \mathrm{H}_{14} \mathrm{~N}_{4} \mathrm{O}_{3}, 250.25$; found (positive mode) $250.9[\mathrm{M}+\mathrm{H}]^{+}$.

2'-Deoxy-1-deazaadenosine-5'-monophosphate (19): To a solution of 7-amino-3-( 2 '-deoxy- $\beta$ D-ribofuranosyl)-imidazo[4,5-b]pyridine $(\mathbf{1 8})(0.1 \mathrm{~g}, 0.4 \mathrm{mmol})$ in dry triethylphosphate $(5.5$ 
$\mathrm{mL})$ at $0^{\circ} \mathrm{C}$, phosphorus oxychloride $(37.0 \mu 1,0.4 \mathrm{mmol})$ was added. The mixture was stirred at $0^{\circ} \mathrm{C}$ for $1 \mathrm{~h}$. Excess of phosphorus oxychloride was hydrolysed by slow addition of aqueous triethylammonium bicarbonate buffer solution (TEAB, $1 \mathrm{M}, \mathrm{pH} \sim 7.5$ ). The crude product was purified on silica column eluting with the following gradient to obtain 2'-deoxy-1deazaadenosine-5'- monophosphate (19) as white solid (75\%): a) iPrOH, b) iPrOH: $\mathrm{H}_{2} \mathrm{O}: \mathrm{NH}_{3}$ (20:1:1), c) iPrOH: $\mathrm{H}_{2} \mathrm{O}: \mathrm{NH}_{3}$ (10:1:1), d) iPrOH: $\mathrm{H}_{2} \mathrm{O}: \mathrm{NH}_{3}$ (7:1:1). TLC (iPrOH/ $\mathrm{H}_{2} \mathrm{O} / \mathrm{NH}_{3}$, 6:2:2): $\mathrm{R}_{f}=0.45 .{ }^{1} \mathrm{H}$ NMR $\left(500 \mathrm{MHz}, \mathrm{D}_{2} \mathrm{O}\right) \delta: 8.36(\mathrm{~s}, 1 \mathrm{H}, \mathrm{H}-8), 7.91\left(\mathrm{~d}, 1 \mathrm{H}, J_{2,1}=6.0 \mathrm{~Hz}, \mathrm{H}-2\right)$, $6.57\left(\mathrm{~d}, 1 \mathrm{H}, J_{1,2}=6.0 \mathrm{~Hz}, \mathrm{H}-1\right), 6.46$ (apparent t, $\left.1 \mathrm{H}, J_{1^{\prime}, 2^{\prime} \mathrm{a}}=J_{1^{\prime}, 2^{\prime} \mathrm{b}}=6.5 \mathrm{~Hz}, \mathrm{H}-1^{\prime}\right), 4.71-4.68(\mathrm{~m}$, 1H, H-3'), 4.28-4.23 (m, 1H, H-4'), 4.05-3.97 (m, 2H, H-5' \& H5"), 2.77-2.71 (m, 1H, H-2'a), 2.57-2.52 (m, 1H, H-2'b). ${ }^{13} \mathrm{C}$ NMR (125MHz, $\left.\mathrm{D}_{2} \mathrm{O}\right)$ 8: 147.6 (C-6), 143.5 (C-4), 142.8 (C-2), 139.1 (C-8), 122.3 (C-5), 103.5 (C-1), 85.7 (C-4'), 83.7 (C-1'), 71.1 (C-3'), 64.1 (C-5'), 38.8 (C$\left.2^{\prime}\right) .{ }^{31} \mathrm{P}$ NMR (121MHz, $\left.\mathrm{D}_{2} \mathrm{O}\right) \delta: 1.83$. HRMS (ESI) calculated for $\mathrm{C}_{11} \mathrm{H}_{15} \mathrm{~N}_{4} \mathrm{O}_{6} \mathrm{P}, 330.0729$; found (negative mode) $329.0594[\mathrm{M}-\mathrm{H}]^{-}$.

2'-Deoxy-1-deazaadenosine-5'-dimethoxyaspartyl phosphoramidate (20): In a two neck flask 2'-deoxy-1-deazaadenosine-5'- monophosphate (19) $(0.06 \mathrm{~g}, 0.18 \mathrm{mmol})$ and L-aspartic acid dimethyl ester hydrochloride $(0.25 \mathrm{~g}, 1.27 \mathrm{mmol})$ were dissolved in a mixture of tert-butanol and water $(5: 1,6.0 \mathrm{~mL})$. Triethylamine $(0.35 \mathrm{~mL})$ was added. $0.37 \mathrm{~mL}$ of freshly prepared solution of $\mathrm{N}, \mathrm{N}^{\prime}$-dicyclohexylcarbodiimide (DCC) in tert-butanol $(0.5 \mathrm{~g} / \mathrm{mL})$ was added dropwise to have 5 equivalents of DCC in the reaction mixture. The reaction mixture was heated for $2-3 \mathrm{~h}$ at $95{ }^{\circ} \mathrm{C}$ while stirring under argon. The progress of the reaction was monitored by TLC (iPrOH: $\mathrm{H}_{2} \mathrm{O}: \mathrm{NH}_{3}, 6: 2: 2$ ) every hour. After $1 \mathrm{~h}$, another 5 equivalents of DCC was added to the reaction mixture. Upon completion the reaction mixture was cooled down to room temperature and the solvent was removed by rotary evaporation keeping the temperature of water bath below $30^{\circ} \mathrm{C}$. The dry residue was suspended in water and washed 3 times with diethyl ether until the water was clear. The aqueous layer was lyophilized and the residue was purified by silica column chromatography by eluting with gradient of $\mathrm{MeOH}$ in $\mathrm{CHCl}_{3}(20 \%$ to $40 \%)$ to obtain 2'-deoxy-1deazaadenosine-5'-dimethoxyaspartyl phosphoramidate (20) as white solid (95\%). TLC $\left(\mathrm{iPrOH} / \mathrm{H}_{2} \mathrm{O} / \mathrm{NH}_{3}, 6: 2: 2\right): \mathrm{R}_{f}=0.73 .{ }^{1} \mathrm{H}$ NMR $(500 \mathrm{MHz}, \mathrm{MeOD}) \delta: 8.41(\mathrm{~s}, 1 \mathrm{H}, \mathrm{H}-8), 7.99(\mathrm{~d}$, $\left.1 \mathrm{H}, J_{2,1}=5.9 \mathrm{~Hz}, \mathrm{H}-2\right), 6.85\left(\mathrm{~d}, 1 \mathrm{H}, J_{1,2}=5.9 \mathrm{~Hz}, \mathrm{H}-1\right), 6.48$ (apparent t, $1 \mathrm{H}, J_{1^{\prime}, 2^{\prime} \mathrm{a}}=J_{1^{\prime}, 2^{\prime} \mathrm{b}}=6.4$ Hz, H-1'), 4.65-4.58 (m, 1H, H-3'), 4.14-3.96 (m, 4H, H-4', H-5', H5" \& H- $\alpha$ ), 3.67 (s, 3H, $\left.\mathrm{CH}_{3}\right), 3.57\left(\mathrm{~s}, 3 \mathrm{H}, \mathrm{CH}_{3}\right) 2.77\left(\mathrm{~d}, 2 \mathrm{H}, J_{\mathrm{H} \alpha, \mathrm{H} \beta}=4.75, \mathrm{H}-\beta\right), 2.70-2.65\left(\mathrm{~m}, 1 \mathrm{H}, \mathrm{H}-2^{\prime} \mathrm{a}\right), 2.46-2.42(\mathrm{~m}$, 
1H, H-2'b). ${ }^{13} \mathrm{C}$ NMR (125 MHz, MeOD) $\delta: 175.1 \& 173.1$ ( $\alpha \& \beta$ CO), 151.5 (C-6), 143.5 (C-4), 142.0 (C-2), 140.7 (C-8), 124.5 (C-5), 104.2 (C-1), 88.2 (C-4'), 86.7 (C-1'), 73.0 (C-3'), 65.7 (C$\left.5^{\prime}\right), 52.9(\mathrm{C}-\alpha), 52.8\left(\mathrm{COO}^{-} H_{3}\right), 52.2\left(\mathrm{COO}^{2} H_{3}\right), 41.6\left(\mathrm{C}-2^{\prime}\right), 39.9(\mathrm{C}-\beta) .{ }^{31} \mathrm{P}$ NMR $(121 \mathrm{MHz}$, MeOD) $\delta$ : 5.28. ES-MS calculated for $\mathrm{C}_{17} \mathrm{H}_{24} \mathrm{~N}_{5} \mathrm{O}_{9} \mathrm{P}, 473.13$; found (negative mode) 471.7 [M$\mathrm{H}]^{-}$.

2'-Deoxy-1-deazaadenosine-5'-aspartyl phosphoramidate (21): A solution (5.9 mL) of $0.4 \mathrm{M}$ $\mathrm{NaOH}$ (in $\mathrm{MeOH} / \mathrm{H}_{2} \mathrm{O}, \quad 4: 1$ ) to 2'-deoxy-1-deazaadenosine-5'-dimethoxyaspartyl phosphoramidate (20) (0.08 g, $0.17 \mathrm{mmol})$ was added. The reaction mixture was stirred at room temperature under argon for 2-3 h. The course of the reaction was monitored by TLC $\left(\mathrm{iPrOH} / \mathrm{H}_{2} \mathrm{O} / \mathrm{NH}_{3}, 6: 2: 2\right)$ until the disappearance of the starting material. The reaction mixture was neutralized by addition of TEAA $(1 \mathrm{M}, \mathrm{pH} \sim 7.5)$. The solvent was removed under reduced pressure and the resulting residue was dried by lyophilization. The desired product was purified by silica column chromatography eluting with the following gradient [iPrOH, iPrOH: $\mathrm{H}_{2} \mathrm{O}: \mathrm{NH}_{3}$ $(20: 1: 1), \quad$ PrOH: $\mathrm{H}_{2} \mathrm{O}: \mathrm{NH}_{3} \quad(10: 1: 1), \quad$ iPrOH$\left.: \mathrm{H}_{2} \mathrm{O}: \mathrm{NH}_{3} \quad(7: 1: 1)\right]$ to obtain 2'-deoxy-1deazaadenosine-5'-aspartyl phosphoramidate (21, 91\%). TLC (iPrOH/ $\left.\mathrm{H}_{2} \mathrm{O} / \mathrm{NH}_{3}, 6: 2: 2\right)$ : $\mathrm{R}_{f}=0.4$. ${ }^{1} \mathrm{H}$ NMR (600 MHz, $\left.\mathrm{D}_{2} \mathrm{O}\right) \delta: 8.35$ (s, 1H, H-8), 7.83 (d, 1H, $\left.J_{2,1}=5.9 \mathrm{~Hz}, \mathrm{H}-2\right), 6.52$ (d, 1H, $J_{1,2}$ $=5.9 \mathrm{~Hz}, \mathrm{H}-1), 6.41\left(\mathrm{dd}, 1 \mathrm{H}, J_{1^{\prime}, 2^{\prime} \mathrm{a}}=7.75 \mathrm{~Hz}, J_{1^{\prime}, 2^{\prime} \mathrm{b}}=6.30 \mathrm{~Hz}, \mathrm{H}-1^{\prime}\right), 4.61-4.58\left(\mathrm{~m}, 1 \mathrm{H}, \mathrm{H}-3^{\prime}\right)$,

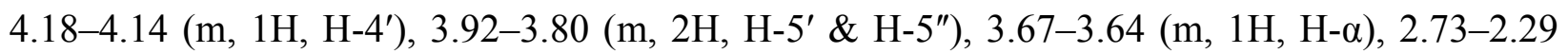
$\left(\mathrm{m}, 4 \mathrm{H}, \mathrm{H}-2^{\prime}, \mathrm{H}-2^{\prime \prime} \& \mathrm{H}-\beta\right) .{ }^{13} \mathrm{C}$ NMR $\left(150 \mathrm{MHz}, \mathrm{D}_{2} \mathrm{O}\right) \delta: 181.2 \& 181.1$ ( $\left.\alpha \& \beta \mathrm{CO}\right), 147.4$ (C6), 144.5 (C-4), 143.6 (C-2), 139.1 (C-8), 122.4 (C-5), 103.8 (C-1), 85.8 (C-4'), 83.4 (C-1'), 71.2 $\left(\mathrm{C}-3^{\prime}\right), 63.8\left(\mathrm{C}-5^{\prime}\right), 54.7$ (C- $\left.\alpha\right), 42.9(\mathrm{C}-\beta), 38.6$ (C-2'). ${ }^{31} \mathrm{P}$ NMR (121 MHz, $\left.\mathrm{D}_{2} \mathrm{O}\right) \delta: 6.50$. HRMS (ESI) calculated for $\mathrm{C}_{15} \mathrm{H}_{20} \mathrm{~N}_{5} \mathrm{O} 9 \mathrm{P}, 445.0998$; found (negative mode) 444.0904 [M-H] ${ }^{-}$.

2'-Deoxy-1-deazaadenosine-5'-methylglycinyl phosphoramidate (22a): TLC $\left(\mathrm{iPrOH} / \mathrm{H}_{2} \mathrm{O} / \mathrm{NH}_{3}, 6: 2: 2\right): \mathrm{R}_{f}=0.76 .{ }^{1} \mathrm{H} \mathrm{NMR}\left(500 \mathrm{MHz}, \mathrm{MeOD}, 15{ }^{\circ} \mathrm{C}\right) \delta: 8.47(\mathrm{~s}, 1 \mathrm{H}, \mathrm{H}-8)$, $7.92\left(\mathrm{~d}, 1 \mathrm{H}, J_{2,1}=6.0 \mathrm{~Hz}, \mathrm{H}-2\right), 6.53\left(\mathrm{~d}, 1 \mathrm{H}, J_{1,2}=6.0 \mathrm{~Hz}, \mathrm{H}-1\right), 6.51$ (apparent t, $1 \mathrm{H}, J_{1^{\prime}, 2^{\prime} \mathrm{a}}=$ $\left.J_{1^{\prime}, 2^{\prime} \mathrm{b}}=6.5 \mathrm{~Hz}, \mathrm{H}-1^{\prime}\right), 4.61-4.60\left(\mathrm{~m}, 1 \mathrm{H}, \mathrm{H}-3^{\prime}\right), 4.12-4.13$ (m, 1H, H-4'), 4.04-4.01 (m, 2H, H-5' \& H-5"), 3.62 (d, 2H, $\left.J_{\mathrm{H} \alpha-\mathrm{P}}=10.5 \mathrm{~Hz}, \mathrm{H}-\alpha\right), 3.59$ (s, 3H, $\left.\mathrm{CH}_{3}\right), 2.75-2.69$ (m, 1H, H-2'a), 2.452.40 (m, 1H, H-2'b). ${ }^{13} \mathrm{C}$ NMR (125 MHz, MeOD) $\delta: 175.5$ (CO), 149.9 (C-6), 145.9 (C-4), 144.3 (C-2), 140.3 (C-8), 124.1 (C-5), 104.2 (C-1), 88.1 (C-4'), 85.6 (C-1'), 73.1 (C-3'), 65.6 (C-5'), 
$52.3\left(\mathrm{COOCH}_{3}\right), 44.3(\mathrm{C}-\alpha), 41.5\left(\mathrm{C}-2^{\prime}\right) .{ }^{31} \mathrm{P}$ NMR $(121 \mathrm{MHz}, \mathrm{MeOD}) \delta: 6.84 . \quad$ ES-MS calculated for $\mathrm{C}_{14} \mathrm{H}_{20} \mathrm{~N}_{5} \mathrm{O}_{7} \mathrm{P}, 401.11$; found (negative mode) $399.7[\mathrm{M}-\mathrm{H}]^{-}$.

2'-Deoxy-1-deazaadenosine-5'-glycinyl phosphoramidate (22): $\mathrm{TLC}\left(\mathrm{iPrOH} / \mathrm{H}_{2} \mathrm{O} / \mathrm{NH}_{3}, 6: 2: 2\right)$ : $\mathrm{R}_{f}=0.63 .{ }^{1} \mathrm{H}$ NMR $\left(600 \mathrm{MHz}, \mathrm{D}_{2} \mathrm{O}, 15^{\circ} \mathrm{C}\right) \delta: 8.34(\mathrm{~s}, 1 \mathrm{H}, \mathrm{H}-8), 7.89\left(\mathrm{~d}, 1 \mathrm{H}, J_{2,1}=6.4 \mathrm{~Hz}, \mathrm{H}-2\right)$, $6.61\left(\mathrm{~d}, 1 \mathrm{H}, J_{1,2}=6.4 \mathrm{~Hz}, \mathrm{H}-1\right), 6.44$ (apparent t, $\left.1 \mathrm{H}, J_{1^{\prime}, 2^{\prime} \mathrm{a}}=J_{1^{\prime}, 2^{\prime} \mathrm{b}}=6.4 \mathrm{~Hz}, \mathrm{H}-1^{\prime}\right), 4.63-4.62(\mathrm{~m}$, 1H, H-3'), 4.24-4.23 (m, 1H, H-4'), 3.98-9.91 (m, 2H, H-5' \& H-5"), 3.27 (d, 2H, $J_{\mathrm{H \alpha}-\mathrm{P}}=8.6 \mathrm{~Hz}$, $\mathrm{H}-\alpha), 2.78-2.73$ (m, 1H, H-2'a), 2.56-2.52 (m, 1H, H-2'b). ${ }^{13} \mathrm{C}$ NMR (150 MHz, $\left.\mathrm{D}_{2} \mathrm{O}, 15^{\circ} \mathrm{C}\right) \delta$ : 178.7 (CO), 149.3 (C-6), 141.8 (C-4), 140.5 (C-2), 139.3 (C-8), 122.6 (C-5), 103.6 (C-1), 85.9 (C-4'), $84.6\left(\mathrm{C}-1^{\prime}\right), 71.2\left(\mathrm{C}-3^{\prime}\right), 63.9\left(\mathrm{C}-5^{\prime}\right), 44.6(\mathrm{C}-\alpha), 38.9\left(\mathrm{C}-2^{\prime}\right) .{ }^{31} \mathrm{P}$ NMR $\left(202 \mathrm{MHz}, \mathrm{D}_{2} \mathrm{O}\right) \delta$ : 8.13. HRMS (ESI) calculated for $\mathrm{C}_{13} \mathrm{H}_{18} \mathrm{~N}_{5} \mathrm{O}_{7} \mathrm{P}, 387.0944$; found (negative mode) 386.0877 [M$\mathrm{H}]^{-}$.

2'-Deoxy-1-deazaadenosine-5'-methyl- $\boldsymbol{\beta}$-alaninyl phosphoramidate (23a): TLC ( $\mathrm{iPrOH} / \mathrm{H}_{2} \mathrm{O}$ / $\left.\mathrm{NH}_{3}, 6: 2: 2\right): \mathrm{R}_{f}=0.80 .{ }^{1} \mathrm{H}$ NMR (500 MHz, MeOD) $\delta: 8.46(\mathrm{~s}, 1 \mathrm{H}, \mathrm{H}-8), 7.87\left(\mathrm{~d}, 1 \mathrm{H}, J_{2,1}=5.7\right.$ $\mathrm{Hz}, \mathrm{H}-2), 6.52$ (apparent t, 1H, $\left.J_{1^{\prime}, 2^{\prime} \mathrm{a}}=J_{1^{\prime}, 2^{\prime} \mathrm{b}}=6.5 \mathrm{~Hz}, \mathrm{H}-1^{\prime}\right), 6.45\left(\mathrm{~d}, 1 \mathrm{H}, J_{1,2}=5.7 \mathrm{~Hz}, \mathrm{H}-1\right)$, 4.61-4.60 (m, 1H, H-3'), 4.14-4.09 (m, 1H, H-4'), 3.98-3.92 (m, 2H, H-5' \& H-5"), 3.60 (s, 3H, $\mathrm{CH}_{3}$ ), 3.12-3.09 (m, 2H, H- $\alpha$ ), 2.79-2.73 (m, 1H, H-2'a), 2.48-2.42 (m, 3H, H-2'b \& H- $\beta$ ). ${ }^{13} \mathrm{C}$

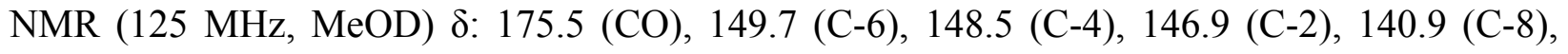
124.8 (C-5), 105.1 (C-1), 88.6 (C-4'), 85.8 (C-1'), $73.9\left(\mathrm{C}-3^{\prime}\right), 66.5\left(\mathrm{C}-5^{\prime}\right), 52.8\left(-\mathrm{COOCH}_{3}\right)$, 42.2 (C-2'), $39.5(\mathrm{C}-\alpha), 38.2(\mathrm{C}-\beta) .{ }^{31} \mathrm{P}$ NMR $\left(202 \mathrm{MHz}, \mathrm{D}_{2} \mathrm{O}\right)$ 8: 7.71. HRMS (ESI) calculated for $\mathrm{C}_{15} \mathrm{H}_{22} \mathrm{~N}_{5} \mathrm{O}_{7} \mathrm{P}, 415.1257$; found (negative mode) $414.1180[\mathrm{M}-\mathrm{H}]^{-}$.

2'-Deoxy-1-deazaasenosine-5'- $\beta$-alaninyl phosphoramidate (23): TLC ( $\mathrm{iPrOH} / \mathrm{H}_{2} \mathrm{O} / \mathrm{NH}_{3}$, 7:1:2): $\mathrm{R}_{f}=0.60 .{ }^{1} \mathrm{H}$ NMR $\left(600 \mathrm{MHz}, \mathrm{D}_{2} \mathrm{O}, 15^{\circ} \mathrm{C}\right) \delta: 8.32(\mathrm{~s}, 1 \mathrm{H}, \mathrm{H}-8), 7.92\left(\mathrm{~d}, 1 \mathrm{H}, J_{2,1}=6.1\right.$ $\mathrm{Hz}, \mathrm{H}-2), 6.53\left(\mathrm{~d}, 1 \mathrm{H}, J_{1,2}=6.1 \mathrm{~Hz}, \mathrm{H}-1\right), 6.40$ (apparent t, $1 \mathrm{H}, J_{1^{\prime}, 2^{\prime} \mathrm{a}}=J_{1^{\prime}, 2^{\prime} \mathrm{b}}=6.8 \mathrm{~Hz}, \mathrm{H}-1^{\prime}$ ), 4.66-4.65 (m, 1H, H-3'), 4.22-4.21 (m, 1H, H-4'), 3.89-3.88 (m, 2H, H-5' \& H-5"), 2.82-2.75 (m, 3H, H- $\alpha$ \& H-2'a), 2.55-2.52 (m, 1H, H-2'b), 2.19 (t, 2H, J = 6.9 Hz, H- $\beta) .{ }^{13} \mathrm{C}$ NMR (150 $\left.\mathrm{MHz}, \mathrm{D}_{2} \mathrm{O}, 15^{\circ} \mathrm{C}\right) \delta: 180.77$ (CO), 148.1 (C-6), 142.3 (C-4), 142.2 (C-2), 139.0 (C-8), 122.4 (C5), 103.7 (C-1), 85.8 (C-4'), 83.9 (C-1'), 71.1 (C-3'), 63.8 (C-5'), 39.0 (C- $\alpha), 38.7$ (C-2'), 38.0 (C$\beta) .{ }^{31} \mathrm{P}$ NMR (121 MHz, $\left.\mathrm{D}_{2} \mathrm{O}\right) \delta: 8.81$. HRMS (ESI) calculated for $\mathrm{C}_{14} \mathrm{H}_{20} \mathrm{~N}_{5} \mathrm{O}_{7} \mathrm{P}, 401.1100$; found (negative mode) $400.1033[\mathrm{M}-\mathrm{H}]^{-}$. 


\section{Synthesis of 7-deazaadenine analogue (Scheme S3)}

4,6-Diamino-5-iodopyrimidine (25): To a suspension of 4,6-diaminopyrimidine (24, available as hemisulfate, monohydrate; $3.9 \mathrm{~g}, 22 \mathrm{mmol})$ in $\mathrm{H}_{2} \mathrm{O}(60 \mathrm{~mL})$ containing $\mathrm{K}_{2} \mathrm{CO}_{3}(4.6 \mathrm{~g}, 33$ $\mathrm{mmol})$, a solution of iodine (6 g, $24 \mathrm{mmol})$ in DMF (14 mL) was added, and the reaction mixture was heated at $45{ }^{\circ} \mathrm{C}$ for $20 \mathrm{~h}$. The reaction was quenched by addition of aqueous solution of sodium thiosulfate $(2 \mathrm{M}, 5 \mathrm{~mL})$. The resulting precipitate was filtered and washed with $\mathrm{H}_{2} \mathrm{O}$ to obtain 4,6-diamino-5-iodopyrimidine (25) as pale brown solid (81\%). TLC (DCM/MeOH, 9.5:0.5): $\mathrm{R}_{f}=0.4 .{ }^{1} \mathrm{H}$ NMR (500 MHz, DMSO-d $\left.\mathrm{d}_{6}\right) \delta: 7.71$ (s, $1 \mathrm{H}, \mathrm{H}-2$ ), 6.30 (br s, $4 \mathrm{H},-\mathrm{NH}_{2}$ ). ${ }^{13} \mathrm{C}$ NMR (125 MHz, DMSO-d 6 ) $\delta: 162.9$ (C-4 \& C-6), 157.1 (C-2), 55.3 (C-5). HRMS (ESI) calculated for $\mathrm{C}_{4} \mathrm{H}_{5} \mathrm{IN}_{4}, 235.9561$; found (positive mode) $236.9624[\mathrm{M}+\mathrm{H}]^{+}$.

4,6-Diamino-5-trimethylsilylethynylpyrimidine (26): A solution of $\mathbf{2 5}$ (4 g, $17 \mathrm{mmol})$ in DMF $(200 \mathrm{~mL})$ containing triethylamine ( $3 \mathrm{~mL}, 20 \mathrm{mmol})$, trimethylsilylacetylene $(5 \mathrm{~mL}, 34 \mathrm{mmol})$,

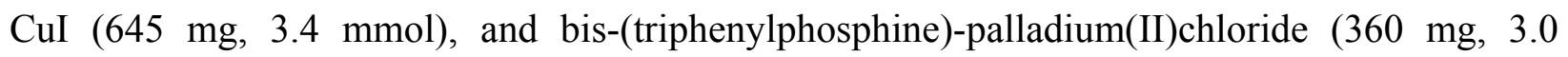
mol\%) was heated at $60{ }^{\circ} \mathrm{C}$ for $2 \mathrm{~h}$. The solvent was removed in vacuo, and the residue was diluted with ethylacetate. The organic layer was washed with 5\% EDTA solution, followed by brine. The organic layer was dried $\left(\mathrm{MgSO}_{4}\right)$ and concentrated in vacuo. The residue was purified by silica gel column chromatography, eluting with hexane/ethylacetate $(1: 1-1: 3)$ to obtain 4,6diamino-5-trimethylsilylethynylpyrimidine (26) as brown solid (70\%). TLC (DCM/MeOH, 9.5:0.5): $\mathrm{R}_{f}=0.3 .{ }^{1} \mathrm{H}$ NMR (300 MHz, $\mathrm{CDCl}_{3}$ ) $\delta: 8.05$ (s, $\left.1 \mathrm{H}, \mathrm{H}-2\right), 5.25$ (br s, 4H, $-\mathrm{NH}_{2}$ ), 0.27 (s, 9H, $\left.\mathrm{Si}\left(\mathrm{CH}_{3}\right)_{3}\right) .{ }^{13} \mathrm{C}$ NMR $\left(75 \mathrm{MHz}, \mathrm{CDCl}_{3}\right) \delta: 163.3$ (C-4 \& C-6), 156.9 (C-2), 107.3 $\left(\mathrm{Si}\left(\mathrm{CH}_{3}\right)_{3} \underline{\mathrm{CC}}-\right), 95.7$ ( $\left.\mathrm{Si}\left(\mathrm{CH}_{3}\right)_{3} \mathrm{C} \underline{\mathrm{C}}-\right), 81.0$ (C-5), 0.1 ( $\left.\mathrm{Si}\left(\underline{\mathrm{CH}}_{3}\right)_{3}\right)$. HRMS (ESI) calculated for $\mathrm{C}_{9} \mathrm{H}_{14} \mathrm{~N}_{4} \mathrm{Si}$, 206.0988; found (positive mode) $207.1065[\mathrm{M}+\mathrm{H}]^{+}$.

4-Amino-7H-pyrrolo[2,3- $\boldsymbol{d}$ ]pyrimidine/7-deazaadenine (27): To a solution of $\mathbf{2 6}$ (3.3 g, 16 $\mathrm{mmol})$ in $N$-methylpyrollidinone $(30 \mathrm{~mL})$, a solution of potassium $t$-butoxide $(2.3 \mathrm{~g}, 21 \mathrm{mmol})$ in $N$-methylpyrollidinone $(90 \mathrm{~mL})$ was added slowly at $90{ }^{\circ} \mathrm{C}$. The reaction mixture was then stirred at the same temperature for $5 \mathrm{~h}$. After cooling at room temperature, the reaction mixture was neutralized with $1 \mathrm{~N} \mathrm{HCl}$, and then the solvent was evaporated to dryness in vacuo. The residue was purified by silica gel column chromatography, eluting with $5-10 \% \mathrm{MeOH}$ in $\mathrm{CHCl}_{3}$ to obtain 27 (1.7 g, 81\%).TLC ( $\left.\mathrm{CHCl}_{3} / \mathrm{MeOH}, 9: 1\right) \mathrm{R}_{f}=0.2 .{ }^{1} \mathrm{H}$ NMR (500 MHz, MeOD) $\delta: 8.05$ (s, $1 \mathrm{H}, \mathrm{H}-2), 7.07$ (d, $\left.1 \mathrm{H}, J_{6,5}=3.5 \mathrm{~Hz}, \mathrm{H}-6\right), 6.55\left(\mathrm{~d}, 1 \mathrm{H}, J_{5,6}=3.5 \mathrm{~Hz}, \mathrm{H}-5\right) .{ }^{13} \mathrm{C}$ NMR $(125$ 
MHz, MeOD) 8: 158.9 (C-4), 151.8 (C-2), 151.0 (C-7a), 122.8 (C-6), 104.0 (C-4a), 100.2 (C-5). HRMS (ESI) calculated for $\mathrm{C}_{6} \mathrm{H}_{6} \mathrm{~N}_{4}, 134.0592$; found (positive mode) $135.0668[\mathrm{M}+\mathrm{H}]^{+}$.

7-(2'-Deoxy-3',5'-di-O-p-toluoyl- $\beta$-D-ribofuranosyl)-4-aminopyrrolo-[2,3- $d]$ pyrimidine (28): A suspension of powdered $\mathrm{KOH}(141 \mathrm{mg}, 2.5 \mathrm{mmol})$ in dry acetonitrile $(8.0 \mathrm{~mL})$ was stirred at room temperature for 10 minutes. Then TDA-1 $(70 \mu \mathrm{L}, 0.2 \mathrm{mmol})$ was added and again stirred for 30 minutes at room temperature. A suspension of 4-amino-7H-pyrrolo[2,3-d]pyrimidine (27, $0.14 \mathrm{~g}, 1.0 \mathrm{mmol})$ in dry acetonitrile $(12.0 \mathrm{~mL})$ was added during 10 minutes and stirring was continued for another 30 minutes. A solution of sugar halide (10, $0.43 \mathrm{~g}, 1.1 \mathrm{mmol})$ was added during 10 minutes and stirring was continued for another 1 hour. Insoluble materials were filtered. The filtrate was evaporated to dryness and the residue was chromatographed on flash silica gel column in $80 \%$ ethyl acetate in hexane to separate $\alpha$ and $\beta$ isomers (28a and 28 respectively). The yield of $\mathbf{2 8}$ was found to be $57 \%$. The more polar N1 isomer (28b) was collected by eluting with ethyl acetate (100\%). TLC (DCM/MeOH, 9.5:0.5): $\mathrm{R}_{f}=0.40 .{ }^{1} \mathrm{H} \mathrm{NMR}$ $\left(300 \mathrm{MHz}, \mathrm{CDCl}_{3}\right) \delta: 8.32(\mathrm{~s}, 1 \mathrm{H}, \mathrm{H}-2), 7.99-7.94(\mathrm{~m}, 4 \mathrm{H}$, aromatic-H), 7.28-7.14 (m, 4H, aromatic-H), $7.15\left(\mathrm{~d}, 1 \mathrm{H}, J_{6,5}=3.6 \mathrm{~Hz}, \mathrm{H}-6\right), 6.82\left(\mathrm{dd}, 1 \mathrm{H}, J_{1^{\prime}, 2^{\prime} \mathrm{a}}=8.3 \mathrm{~Hz}, J_{1^{\prime}, 2^{\prime} \mathrm{b}}=5.7 \mathrm{~Hz}, \mathrm{H}-1^{\prime}\right)$, $6.39\left(\mathrm{~d}, 1 \mathrm{H}, J_{5,6}=3.6 \mathrm{~Hz}, \mathrm{H}-5\right), 5.76-5.74$ (m, 1H, H-3'), 5.54 (br s, 2H, NH ), $4.72-4.59$ (m, 3H, H-4', H-5' \& H-5"), 2.90-2.69 (m, 2H, H-2'a \& H-2'b), 2.43 (s, 3H, aromatic- $\mathrm{CH}_{3}$ ), 2.41 (s, $3 \mathrm{H}$, aromatic- $\left.\mathrm{CH}_{3}\right) .{ }^{13} \mathrm{C} \mathrm{NMR}\left(75 \mathrm{MHz}, \mathrm{CDCl}_{3}\right) \delta: 165.9 \& 165.8$ (CO), 156.4 (C-4), 151.9 (C2), 150.5 (C-7a), 144.1 \& 143.7 (aromatic ring C), 129.5-126.2 (aromatic ring C), 120.9 (C-6), 103.4 (C-4a), 98.9 (C-5), 83.5 (C-1'), 81.6 (C-4'), 74.9 (C-3'), 64.1 (C-5'), 37.7 (C-2'), 21.4 (aromatic- $\mathrm{CH}_{3}$ ). HRMS (ESI) calculated for $\mathrm{C}_{27} \mathrm{H}_{26} \mathrm{~N}_{4} \mathrm{O}_{5}, 486.1903$; found (positive mode) $487.1974[\mathrm{M}+\mathrm{H}]^{+}$.

\section{7-(2'-Deoxy-3',5'-di- $O$-p-toluoyl- $\alpha$-D-ribofuranosyl)-4-aminopyrrolo-[2,3- $d]$ pyrimidine}

(28a): ${ }^{1} \mathrm{H}$ NMR $\left(300 \mathrm{MHz}, \mathrm{CDCl}_{3}\right.$ ) $\delta: 8.32$ (s, 1H, H-2), 7.99-7.80 (m, 4H, aromatic-H), 7.15 (d, $\left.1 \mathrm{H}, J_{6,5}=3.7 \mathrm{~Hz}, \mathrm{H}-6\right), 7.39-7.23\left(\mathrm{~m}, 4 \mathrm{H}\right.$, aromatic-H), $6.82\left(\mathrm{dd}, 1 \mathrm{H}, J_{1^{\prime}, 2^{\prime} \mathrm{a}}=9.2 \mathrm{~Hz}, J_{1^{\prime}, 2^{\prime} \mathrm{b}}=2.3\right.$ Hz, H-1'), 6.43 (d, 1H, J5,6 $=3.7$ Hz, H-5), 5.69-5.67 (m, 1H, H-3'), 5.50 (br s, 2H, NH ) 4.874.86 (m, 1H, H-4'), 4.61-4.60 (m, 2H, H-5' \& H-5"), 3.18-2.80 (m, 2H, H-2'a \& H-2'b), 2.44 (s, $6 \mathrm{H}$, aromatic- $\left.\mathrm{CH}_{3}\right) .{ }^{13} \mathrm{C} \mathrm{NMR}\left(75 \mathrm{MHz}, \mathrm{CDCl}_{3}\right) \delta: 165.8 \& 165.7(\mathrm{CO}), 156.4(\mathrm{C}-4), 151.7(\mathrm{C}-$ 2), 150.9 (C-7a), 144.1 \& 143.7 (aromatic ring C), 129.5-126.2 (aromatic ring C), 121.5 (C-6), 
103.4 (C-4a), 98.0 (C-5), $84.6\left(\mathrm{C}-1^{\prime}\right), 83.3\left(\mathrm{C}-4^{\prime}\right), 75.0\left(\mathrm{C}-3^{\prime}\right), 64.1\left(\mathrm{C}-5^{\prime}\right), 38.2\left(\mathrm{C}-2^{\prime}\right), 21.4$ (aromatic- $\mathrm{CH}_{3}$ ).

\section{1-(2'-Deoxy-3',5'-di- $O$ - $p$-toluoyl- $\beta$-D-ribofuranosyl)-4-aminopyrrolo-[2,3- $d]$ pyrimidine}

(28b): TLC (DCM/MeOH, 9.5:0.5): $\mathrm{R}_{f}=0.1 .{ }^{1} \mathrm{H}$ NMR (500 MHz, $\left.\mathrm{CDCl}_{3}\right) \delta: 8.48(\mathrm{~s}, 1 \mathrm{H}, \mathrm{H}-2)$, 7.99-7.83 (m, 4H, aromatic-H), 7.50 (br s, 1H, H-6), 7.28-7.18 (m, 4H, aromatic-H), 6.98 (apparent t, 1H, $\left.J_{1^{\prime}, 2^{\prime} \mathrm{a}}=J_{1^{\prime}, 2^{\prime} \mathrm{b}}=6.7 \mathrm{~Hz}, \mathrm{H}-1^{\prime}\right), 6.51$ (br s, 1H, H-5), 5.69-5.67 (m, 1H, H-3'), 5.44 (br s, 2H, NH $\mathrm{N}_{2}$ ), 4.79-4.73 (m, 3H, H-4', H-5' \& H-5"), 3.32-3.23 (m, 1H, H-2'a), 2.64-2.58 (m, $1 \mathrm{H}, \mathrm{H}-2 \mathrm{~b}$ ), 2.44 (s, 3H, aromatic- $\left.\mathrm{CH}_{3}\right), 2.39$ (s, 3H, aromatic- $\left.\mathrm{CH}_{3}\right) .{ }^{13} \mathrm{C}$ NMR $(125 \mathrm{MHz}$, $\left.\mathrm{CDCl}_{3}\right) \delta: 166.5 \& 166.4(\mathrm{CO}), 155.9(\mathrm{C}-4), 146.4$ (C-7a), $144.9 \& 144.6$ (aromatic ring C), 139.4 (C-6), 137.9 (C-2),130.3-126.7 (aromatic ring C), 105.5 (C-4a), 98.8 (C-5), 89.1 (C-1'), $84.3\left(\mathrm{C}-4^{\prime}\right), 75.2\left(\mathrm{C}-3^{\prime}\right), 64.5\left(\mathrm{C}-5^{\prime}\right), 40.5\left(\mathrm{C}-2^{\prime}\right), 22.0$ (aromatic- $\left.\mathrm{CH}_{3}\right)$.

\section{7-(2'-deoxy- $\beta$-D-ribofuranosyl)-4-aminopyrrolo-[2,3- $d]$ pyrimidine/2'-deoxy-7-}

deazaadenosine (29): Toluoyl group deprotection reaction was performed according to the procedure mentioned for compound 17, keeping the reaction mixture at room temperature for 48 hours. TLC (DCM/MeOH, 9.5:0.5): $\mathrm{R}_{f}=0.1 .{ }^{1} \mathrm{H}$ NMR (300 MHz, DMSO-d 6 ) $\delta: 8.04$ (s, $1 \mathrm{H}, \mathrm{H}-$ 2), 7.34 (d, $\left.1 \mathrm{H}, J_{6,5}=3.6 \mathrm{~Hz}, \mathrm{H}-6\right), 7.02$ (br s, $2 \mathrm{H}, \mathrm{NH}_{2}$ ), 6.58 (d, $\left.1 \mathrm{H}, J_{6,5}=3.6 \mathrm{~Hz}, \mathrm{H}-5\right), 6.47$ (dd, $\left.1 \mathrm{H}, J_{1^{\prime}, 2^{\prime} \mathrm{a}}=8.01 \mathrm{~Hz}, J_{1^{\prime}, 2^{\prime} \mathrm{b}}=6.0 \mathrm{~Hz}, \mathrm{H}^{\prime} 1^{\prime}\right), 5.26\left(\mathrm{~d}, 1 \mathrm{H}, 3^{\prime}-\mathrm{OH}\right), 5.18\left(\mathrm{t}, 1 \mathrm{H}, 5^{\prime}-\mathrm{OH}\right), 4.34-$ 4.33 (m, 1H, H-3'), 3.82-3.41 (m, 3H, H-4', H-5' \& H-5"), 2.51-2.12 (m, 2H, H-2'a \& H-2'b). ${ }^{13} \mathrm{C}$ NMR (75 MHz, DMSO-d 6 ) $8: 158.5$ (C-4), 152.6 (C-2), 150.6 (C-7a), 122.6 (C-6), 103.9 (C4a), 100.7 (C-5), 88.2 (C-4'), 84.3 (C-1'), 72.1 (C-3'), $63.1\left(\mathrm{C}^{\prime} 5^{\prime}\right), 40.4\left(\mathrm{C}-2^{\prime}\right)$. Yield = 95\%. HRMS (ESI) calculated for $\mathrm{C}_{11} \mathrm{H}_{14} \mathrm{~N}_{4} \mathrm{O}_{3}, 250.1066$; found (positive mode) $251.1132[\mathrm{M}+\mathrm{H}]^{+}$.

2'-Deoxy-7-deazaadenosine-5'-monophosphate (30): $\mathrm{TLC}\left(\mathrm{iPrOH} / \mathrm{H}_{2} \mathrm{O} / \mathrm{NH}_{3}, 6: 2: 2\right): \mathrm{R}_{f}=0.3$. ${ }^{1} \mathrm{H}$ NMR (500 MHz, D $\left.2 \mathrm{O}\right) \delta: 8.04$ (s, $\left.1 \mathrm{H}, \mathrm{H}-2\right), 7.49$ (d, $\left.1 \mathrm{H}, J_{8,7}=3.7 \mathrm{~Hz}, \mathrm{H}-8\right), 6.57-6.54$ (m, 2H, H-7 \& H-1'), 4.68-4.67 (m, 1H, H-3'), 4.19-4.18 (m, 1H, H-4'), 4.00-3.98 (m, 2H, H-5' \& $\left.\mathrm{H}-5^{\prime \prime}\right), \quad 2.69-2.63$ (m, 1H, H-2'a), 2.47-2.45 (m, 1H, H-2'b). ${ }^{13} \mathrm{C}$ NMR (125 MHz, $\left.\mathrm{D}_{2} \mathrm{O}\right) \delta: 154.5$ (C-6), 147.7 (C-4 \& C-2), 122.5 (C-8), 102.3 (C-5), 100.7 (C-7), 85.1 (C-4'), 82.6 (C-1'), 71.1 $\left(\mathrm{C}-3^{\prime}\right), 64.1\left(\mathrm{C}-5^{\prime}\right), 38.5\left(\mathrm{C}-2^{\prime}\right) .{ }^{31} \mathrm{P}$ NMR $\left(121 \mathrm{MHz}, \mathrm{D}_{2} \mathrm{O}\right) \delta: 1.87$. Yield $=81 \%$. HRMS (ESI) calculated for $\mathrm{C}_{11} \mathrm{H}_{15} \mathrm{~N}_{4} \mathrm{O}_{6} \mathrm{P}, 330.0729$; found (negative mode) $329.0653[\mathrm{M}-\mathrm{H}]^{-}$. 
2'-Deoxy-7-deazaadenosine-5'-dimethoxyaspartyl phosphoramidate (31): TLC $\left(\mathrm{iPrOH} / \mathrm{H}_{2} \mathrm{O} / \mathrm{NH}_{3}, 6: 2: 2\right): \mathrm{R}_{f}=0.8 .{ }^{1} \mathrm{H}$ NMR $\left(500 \mathrm{MHz}, \mathrm{D}_{2} \mathrm{O}\right): \delta: 8.15$ (s, $\left.1 \mathrm{H}, \mathrm{H}-2\right), 7.58(\mathrm{~d}, 1 \mathrm{H}$, $\left.J_{8,7}=3.7 \mathrm{~Hz}, \mathrm{H}-8\right), 6.72\left(\mathrm{~d}, 1 \mathrm{H}, J_{7,8}=3.7 \mathrm{~Hz}, \mathrm{H}-7\right), 6.60$ (apparent t, $1 \mathrm{H}, J_{1^{\prime}, 2^{\prime} \mathrm{a}}=J_{1^{\prime}, 2^{\prime} \mathrm{b}}=6.8 \mathrm{~Hz}$, H-1'), 4.69-4.68 (m, 1H, H-3'), 4.20-4.19 (m, 1H, H-4'), 4.00-3.96 (m, 3H, H-5', H-5" \& H- $)$ ), 3.69 (s, 3H, $\mathrm{CH}_{3}$ ), 3.59 (s, 3H, $\mathrm{CH}_{3}$ ), 2.72-2.67 (m, 3H, H-2'a \& H- $\beta$ ), 2.52-2.48 (m, 1H, H-2'b). ${ }^{13} \mathrm{C}$ NMR $\left(125 \mathrm{MHz}, \mathrm{D}_{2} \mathrm{O}\right) \delta: 174.8$ \& $172.9(\alpha \& \beta \mathrm{CO}), 151.6(\mathrm{C}-6), 146.8(\mathrm{C}-4), 143.6(\mathrm{C}-2)$, 123.9 (C-8), 101.9 (C-5), 101.6 (C-7), 85.2 (C-4'), 83.0 (C-1'), 71.1 (C-3'), 63.9 (C-5'), 52.5 $\left(\mathrm{COOCH}{ }_{3}\right), 51.9\left(\mathrm{COOCH}_{3}\right), 50.9(\mathrm{C}-\alpha), 38.7\left(\mathrm{C}-2^{\prime}\right), 38.1(\mathrm{C}-\beta) .{ }^{31} \mathrm{P}$ NMR $\left(121 \mathrm{MHz}, \mathrm{D}_{2} \mathrm{O}\right) \delta$ : 5.77. Yield $=70 \%$. HRMS (ESI) calculated for $\mathrm{C}_{17} \mathrm{H}_{24} \mathrm{~N}_{5} \mathrm{O}_{9} \mathrm{P}, 473.1312$; found (negative mode) $472.1235[\mathrm{M}-\mathrm{H}]^{-}$.

2'-Deoxy-7-deazaadenosine-5'-aspartyl phosphoramidate (32): TLC ( $\mathrm{PrOH} / \mathrm{H}_{2} \mathrm{O} / \mathrm{NH}_{3}$, 6:2:2): $\mathrm{R}_{f}=0.3 .{ }^{1} \mathrm{H}$ NMR (500 MHz, $\left.\mathrm{D}_{2} \mathrm{O}\right): \delta: 8.14$ (s, $\left.1 \mathrm{H}, \mathrm{H}-2\right), 7.56\left(\mathrm{~d}, 1 \mathrm{H}, J_{8,7}=3.8 \mathrm{~Hz}, \mathrm{H}-8\right)$, $6.69\left(\mathrm{~d}, 1 \mathrm{H}, J_{7,8}=3.8 \mathrm{~Hz}, \mathrm{H}-7\right), 6.65$ (apparent t, $\left.1 \mathrm{H}, J_{1^{\prime}, 2^{\prime} \mathrm{a}}=J_{1^{\prime}, 2^{\prime} \mathrm{b}}=6.8 \mathrm{~Hz}, \mathrm{H}-1^{\prime}\right), 4.69-4.65(\mathrm{~m}$, 1H, H-3'), 4.21-4.17 (m, 1H, H-4'), 3.99-3.86 (m, 2H, H-5' \& H-5"), 3.79-3.75 (m, 1H, H- $\alpha$ ), 2.82-2.67 (m, 4H, H-2'a, H-2'b \& H- $\beta$ ). ${ }^{13} \mathrm{C}$ NMR (125 MHz, $\left.\mathrm{D}_{2} \mathrm{O}\right) \delta: 180.9 \& 177.1(\alpha \& \beta$ CO), 156.1 (C-6), 149.7 (C-2), 148.6 (C-4), 122.2 (C-8), 102.7 (C-5), 100.5 (C-7), 85.2 (C-4'), $82.7\left(\mathrm{C}-1^{\prime}\right), 71.4\left(\mathrm{C}-3^{\prime}\right), 63.8$ (C-5'), 54.5 (C- $\left.\alpha\right), 42.8(\mathrm{C}-\beta), 38.3\left(\mathrm{C}-2^{\prime}\right) .{ }^{31} \mathrm{P}$ NMR $(121 \mathrm{MHz}$, $\mathrm{D}_{2} \mathrm{O}$ ) $\delta$ : 7.00. Yield $=80 \%$. HRMS (ESI) calculated for $\mathrm{C}_{15} \mathrm{H}_{20} \mathrm{~N}_{5} \mathrm{O}_{9} \mathrm{P}, 445.0998$; found (negative mode) $444.0919[\mathrm{M}-\mathrm{H}]^{-}$.

2'-Deoxy-3-deazaadenosine-5'-aspartyl phosphoramidate (33): TLC $\left(\mathrm{iPrOH} / \mathrm{H}_{2} \mathrm{O} / \mathrm{NH}_{3}\right.$, 6:2:2): $\mathrm{R}_{f}=0.3 .{ }^{1} \mathrm{H}$ NMR $\left(500 \mathrm{MHz}, \mathrm{D}_{2} \mathrm{O}\right): \delta: 8.51(\mathrm{~s}, 1 \mathrm{H}, \mathrm{H}-8), 7.56\left(\mathrm{~d}, 1 \mathrm{H}, J_{2,3}=7.1 \mathrm{~Hz}, \mathrm{H}-2\right)$, 7.20 (d, $\left.1 \mathrm{H}, J_{3,2}=3.8 \mathrm{~Hz}, \mathrm{H}-3\right), 6.85$ (apparent t, $\left.1 \mathrm{H}, J_{1^{\prime}, 2^{\prime} \mathrm{a}}=J_{1^{\prime}, 2^{\prime} \mathrm{b}}=6.8 \mathrm{~Hz}, \mathrm{H}-1^{\prime}\right), 4.70-4.67$ (m, 1H, H-3'), 4.28-4.24 (m, 1H, H-4'), 4.06-3.97 (m, 2H, H-5' \& H-5"), 3.80-3.75 (m, 1H, H- $\alpha$ ), 2.74-2.41 (m, 4H, H-2'a, H-2'b \& H- $\beta$ ). ${ }^{13} \mathrm{C}$ NMR (125 MHz, $\left.\mathrm{D}_{2} \mathrm{O}\right) \delta: 180.8 \& 178.9(\alpha \& \beta$ CO), 147.7 (C-6), 142.8 (C-8), 138.9 (C-4), 129.3 (C-2), 125.4 (C-5), 99.1 (C-3), 86.0 (C-4'), $85.4\left(\mathrm{C}-1^{\prime}\right), 70.6\left(\mathrm{C}-3^{\prime}\right), 63.5\left(\mathrm{C}-5^{\prime}\right), 54.4(\mathrm{C}-\alpha), 42.6(\mathrm{C}-\beta), 39.3\left(\mathrm{C}-2^{\prime}\right) .{ }^{31} \mathrm{P}$ NMR (121MHz, $\left.\mathrm{D}_{2} \mathrm{O}\right) \delta$ : 6.95. Yield $=50 \%$. HRMS (ESI) calculated for $\mathrm{C}_{15} \mathrm{H}_{20} \mathrm{~N}_{5} \mathrm{O}_{9} \mathrm{P}, 445.0998$; found (negative mode) 444.0910 [M-H] ${ }^{-}$. 